Florida International University

FIU Digital Commons

FIU Electronic Theses and Dissertations

University Graduate School

6-25-2019

\title{
Assessment of Watersheds for Sustainable Agriculture in Karnataka, India
}

Nicholas Adam Charles

Florida International University, nchar042@fiu.edu

Follow this and additional works at: https://digitalcommons.fiu.edu/etd

Part of the Agricultural Economics Commons, Environmental Studies Commons, Food Security Commons, Geographic Information Sciences Commons, and the Remote Sensing Commons

\section{Recommended Citation}

Charles, Nicholas Adam, "Assessment of Watersheds for Sustainable Agriculture in Karnataka, India" (2019). FIU Electronic Theses and Dissertations. 4236.

https://digitalcommons.fiu.edu/etd/4236

This work is brought to you for free and open access by the University Graduate School at FIU Digital Commons. It has been accepted for inclusion in FIU Electronic Theses and Dissertations by an authorized administrator of FIU Digital Commons. For more information, please contact dcc@fiu.edu. 


\section{FLORIDA INTERNATIONAL UNIVERSITY}

Miami, Florida

\section{ASSESSMENT OF WATERSHEDS FOR SUSTAINABLE AGRICULTURE IN \\ KARNATAKA, INDIA}

A thesis submitted in partial fulfillment of

the requirements for the degree of

MASTER OF SCIENCE

in

ENVIRONMENTAL STUDIES

by

Nicholas Charles

2019 
To: Dean Michael R. Heithaus

College of Arts, Sciences and Education

This thesis, written by Nicholas Charles, and entitled Assessment of Watersheds for Sustainable Agriculture in Karnataka, India, having been approved in respect to style and intellectual content, is referred to you for judgment.

We have read this thesis and recommend that it be approved.

$\begin{array}{r}\text { Daniel Gann } \\ \hline \text { Assefa Melesse } \\ \hline \text { Mahadev Bhat, Major Professor }\end{array}$

Date of Defense: June 25, 2019

The thesis of Nicholas Charles is approved.

Dean Michael R. Heithaus

College of Arts, Sciences and Education

Andrés G. Gil

Vice President for Research and Economic Development and Dean of the University Graduate School

Florida International University, 2019 


\section{ACKNOWLEDGMENTS}

I would like to thank my major advisor, Dr. Mahadev Bhat, for his guidance and assistance during my graduate career. He provided me with many excellent opportunities and played a large role in my personal and professional growth. I want to thank Dr. Assefa Melesse for being an excellent mentor with GIS in water resources and for expanding my passion for the GIS field. I would also like to thank Dr. Daniel Gann, who was quick to sign on as my committee member and for assisting me tremendously with remote sensing and image classification.

I am extremely grateful to the Hulgol Cooperative Society for giving me the resources and support necessary for successful data collection while in Karnataka, India. Furthermore, I thank Dr. Ramachandra Bhatta for always being willing to help gather secondary data. I thank my fellow Earth \& Environment graduate students - Claudia Garcia, Mary Tiedemen, Jessica Dominguez, Jordan Prats, Daphne Sugino, Chloe Vorseth, Aldo Farah, Anna Fache, and Christina Brown for giving me support, data processing assistance, and guidance throughout my graduate career. I am grateful to Ariel Freidenreich for always making sure I keep myself hydrated. I also thank the Agroecology lab manager, Eric Betancourt, for the time he has dedicated to the program.

I want to thank my parents, Robert and Faith Charles, along with my Grandfather, James Charles, for being amazing role models and giving me the confidence and support that I needed to succeed. Finally, I would like to thank the United States Department of Agriculture (2016-38422-25549) and National Science Foundation (EAR-1204762) for funding my research. 


\title{
ABSTRACT OF THE THESIS
}

\section{ASSESSMENT OF WATERSHEDS FOR SUSTAINABLE AGRICULTURE IN KARNATAKA, INDIA}

by

\author{
Nicholas Charles
}

Florida International University, 2019

Miami, Florida

\section{Professor Mahadev Bhat, Major Professor}

Modernization of traditional small-scale irrigation tanks in India is becoming increasingly popular. Thousands of small surface-water irrigation tanks that spread across agricultural landscape in Karnataka, India, constitute an important part of water resources. The goal of the present study was to develop a stakeholder-informed approach to identifying and prioritizing restoration needs of irrigation tanks to meet future agricultural/household demand for water in rural Karnataka, India. Tanks were characterized on the basis of hydrological (rainwater storage), physical and environmental conditions. Alternatively, the viability of a large-scale lift irrigation scheme was also evaluated using survey respondents' annual agricultural yields and water use. The results give a valuable substitute for the current assessment and prioritization of irrigation tanks. The lift irrigation scheme is expected to deliver a net present value to the farming community. Spatially referenced hydrological outputs can be applied to conservation strategies for better management of water resources throughout Southeast Asia. 


\section{TABLE OF CONTENTS}

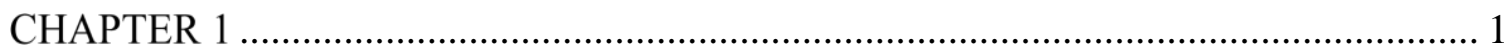

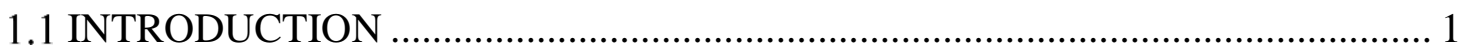



1.2.1 Application of Remote Sensing ................................................................ 4

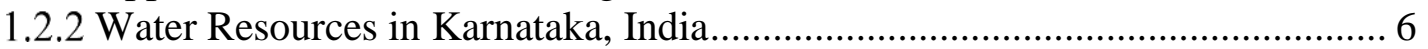

1.2.3 SCS-CN Runoff Estimation Model Integration .............................................. 9

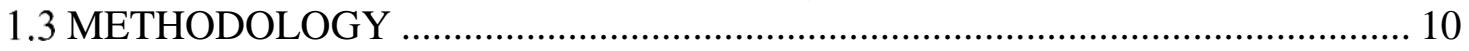

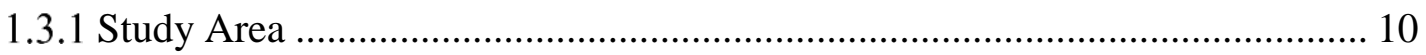

1.3.2 Land Use Data/Variable Selection .............................................................. 12

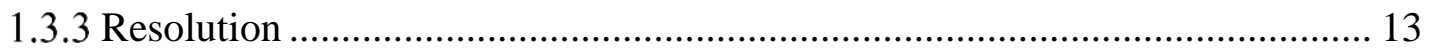

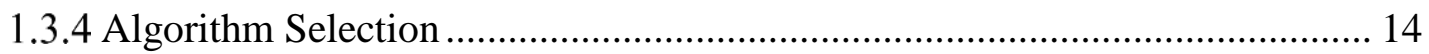

1.3.5 Accuracy Assessment ............................................................................... 14

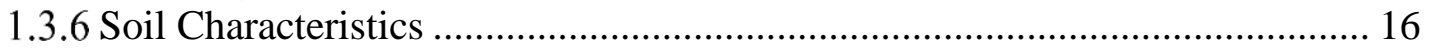

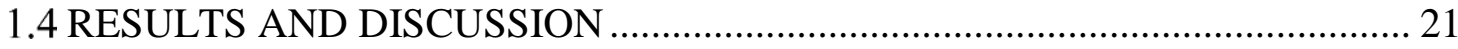

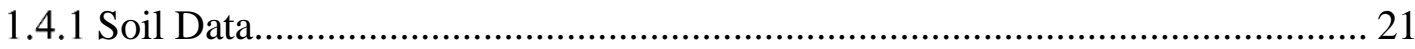

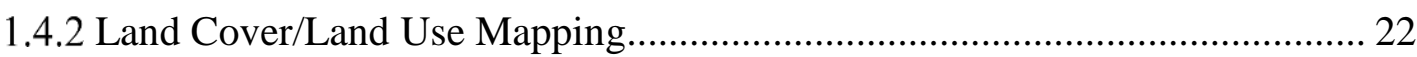

1.4.3 Irrigation Tank Command Area Delineation ................................................... 29

1.4.4 Curve Number Estimation ................................................................................ 34

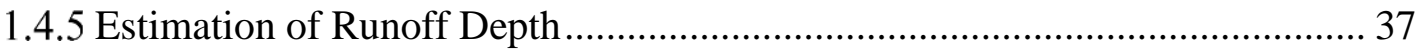

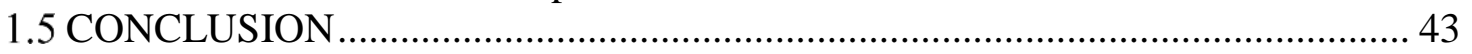

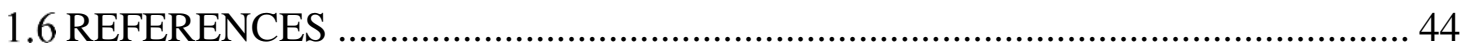

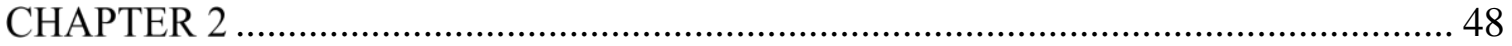

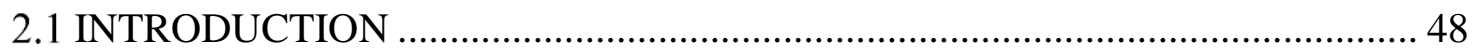

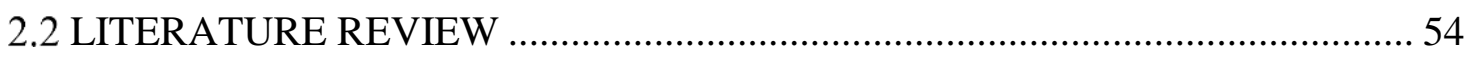

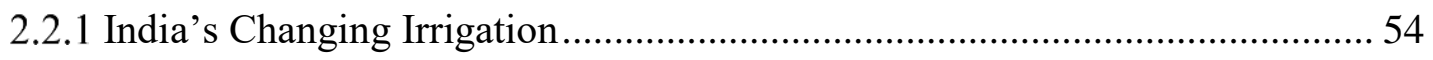

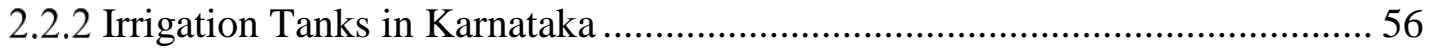

2.2.3 Restoration and Participatory Management .................................................... 63

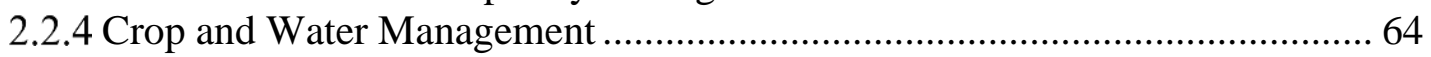

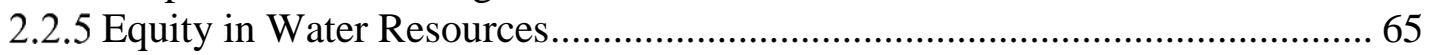

2.2.6 Multi Criteria Analysis for Water Resource Assessment ................................. 65

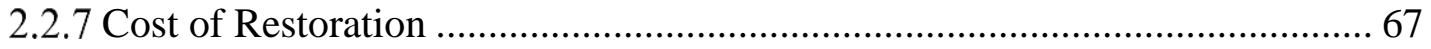

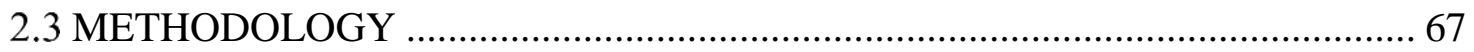

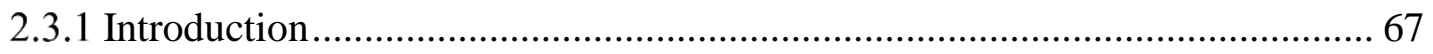

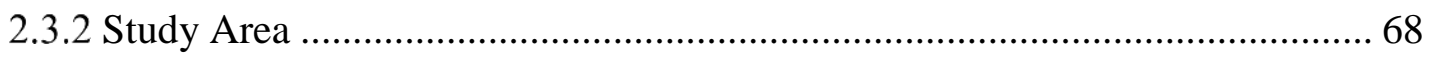

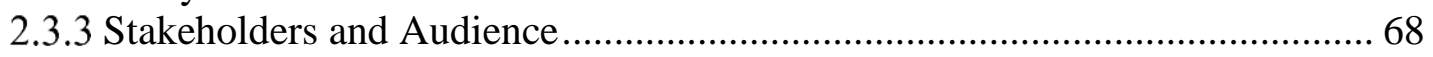

2.3.4 Delineation of Tank Resources in Study Area..................................................69

2.3.5 Significance of Tank Resources in the Study Area ......................................... 69

2.3.6 Relevant Attributes and Sustainability......................................................... 70

2.3.7 Water Resource Attributes for Multi-Criteria Analysis.................................... 73

2.3.8 Normalized Indicator Valuation .................................................................. 73

2.3.9 Weighing Stakeholder Attribute Interests: Analytic Hierarchy Process.......... 74 


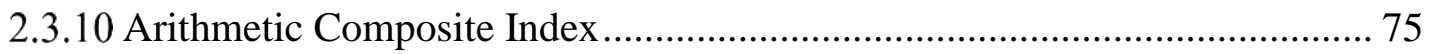

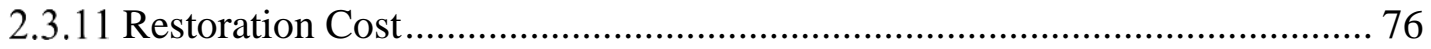

2.3.12 Sustainable Equity through Food Security ................................................ 76

2.3.13 Multi-Objective Analysis........................................................................ 77

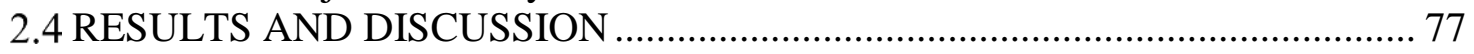

2.4.1 Multi-criteria (Indicator) Performance Values ................................................ 83

2.4.2 Analytical Hierarchy Process Weights ........................................................ 86

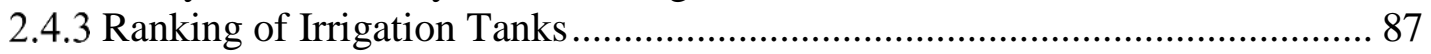

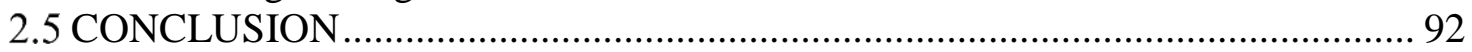

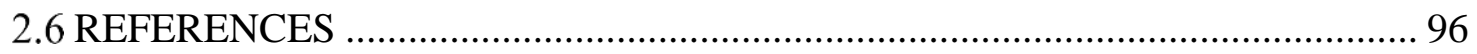

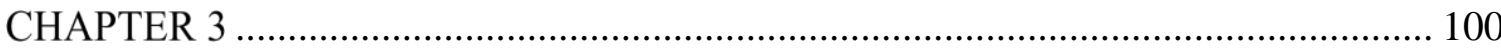

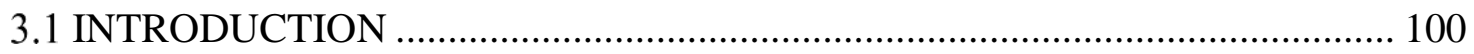

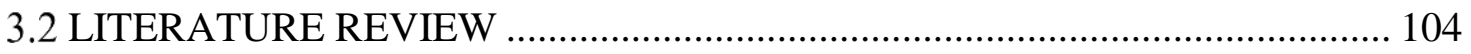

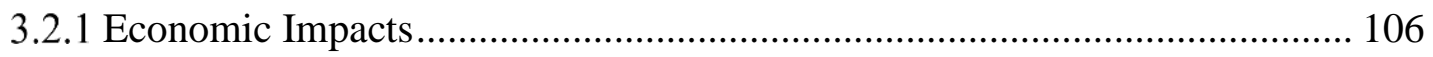

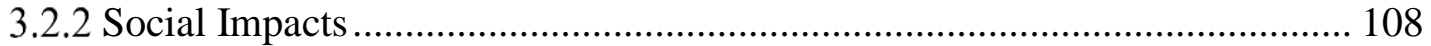

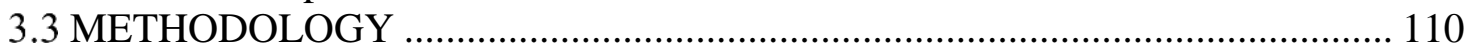

3.3.1 Overview of Data Collection ................................................................... 110

3.3.2 Household Surveys …………………………………………………..... 112

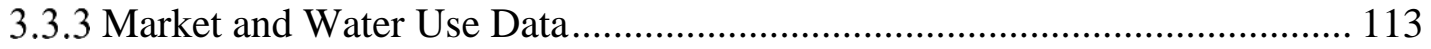

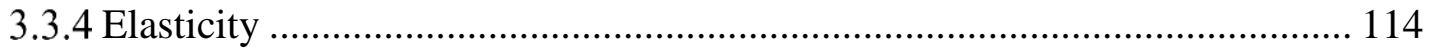

3.3.5 Command Area Delineation ....................................................................... 115

3.3.6 Water Elasticity of Gross Agricultural Revenue .......................................... 116

3.3.7 Benefit Cost Analysis/Net Present Value ........................................................ 117

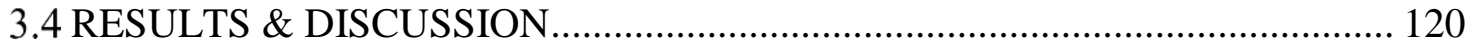

3.4.1 Farmers Perceptions of Lift Irrigation Project .............................................. 121

3.4.2 Log-Linear Regression Analysis.................................................................. 122

3.4.3 Water Resources, Gross Revenue, and Net Profit Benefits ........................... 124

3.4.4 Viability of Lift Irrigation Project Scenarios ................................................. 127

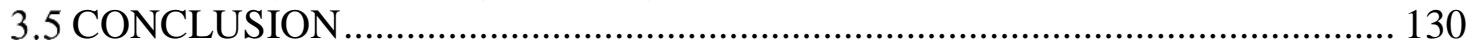

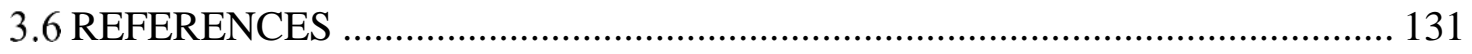

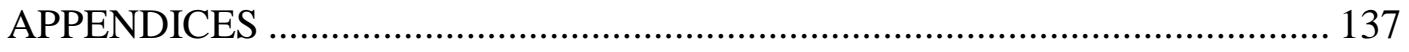


Table 1-1. Climate variables, topographical maps, and satellite imagery for surface runoff modeling

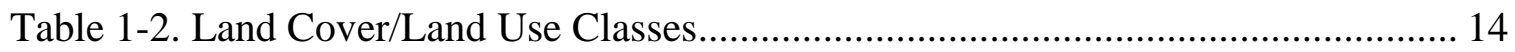

Table 1-3. USDA-SCS Soil Classification Scheme.................................................... 16

Table 1-4. Yearly recorded rainfall data for the Bhairumbe/Taragod Panchayats, Taragod Station

Table 1-5. Values of antecedent moisture conditions based on seasonality and 5-day antecedent rainfall patterns ................................................................................ 19

Table 1-6. Soil types and their corresponding HSG value and extent in the study area... 21

Table 1-7. Surface area of land use/land cover classes in the Bhairumbe/Taragod

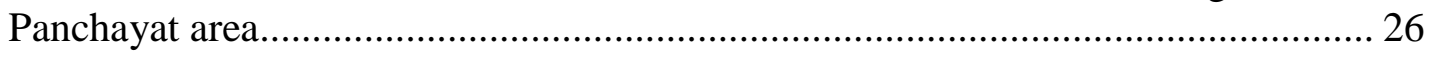

Table 1-8. Confusion matrix of 7 land use classes using a sample size of 665 .............. 27

Table 1-9. Overall command area and crop acreage irrigation ( $85.11 \%$ accuracy) by

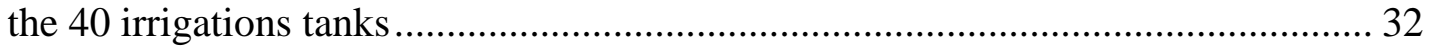

Table 1-10. Distribution of land use/land cover with respective HSG and Curve Number statistics

Table 1-11. Estimation of runoff using weighted curve numbers and rainfall events



Table 1-12. Yearly rainfall compared with runoff between the months of May - November

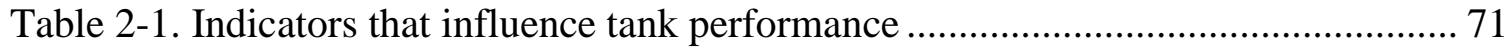

Table 2-2. Values and definitions of variables in the Saaty scale used for Analytical

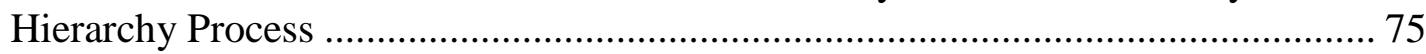

Table 2-3. Observed tanks in the Bhairumbe/Taragod Panchayats ............................... 78

Table 2-4. Top 10 tanks ranked by largest irrigated command area.............................. 87 
Table 2-5. Top 10 tanks ranked by highest arithmetic composite index value. 88

Table 2-6. Top 10 tanks ranked by highest rice paddy percentage in command area ...... 90

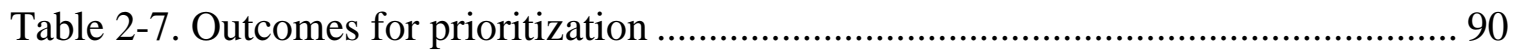

Table 2-8. Year 1 scenario for priority restoration of irrigation tanks under budget constraints

Table 3-1. Irrigation sources in the region of india based off 2002 IWMI survey results (Shah et al. 2006)

Table 3-2. Socio-economic and technical variables and their defined roles for surface irrigation management in modern day India (Mukhedrji et al. 2009)

Table 3-3. Costs of construction and maintenance for proposed lift irrigation project in Lakhs (source: Government of Karnataka, Minor Irrigation Department) ......... 111

Table 3-4. Breakdown of surveys collected from the study area based on 2011 census of India

Table 3-5. Acreage, average price and average per acre yield of crop types found in the command area of ten project tanks

Table 3-6. Economics of relevant crops in the Bhairumbe/Taragod Panchayats, adapted

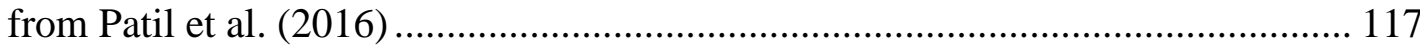

Table 3-7. Summary output of Log-Linear model with intercept............................... 123

Table 3-8. Summary output of Log-Linear model without intercept.......................... 123

Table 3-9. Scenarios of gross revenue increase with water elasticity and water increase variables

Table 3-10. Scenarios of net profits with water elasticity and water increase variables, based off $45 \%$ of agricultural revenue (Patil et al. 2016) .................................... 126

Table 3-11. Scenarios of gross revenue with water elasticity and water increase variables, based off $20 \%$ of agricultural revenue (Patil et al. 2016)

Table 3-12. Net Present Values and Benefit-Cost Ratios for the proposed lift irrigation project at $5 \%$ Discount Rate 
Table 3-13. Net Present Values and Benefit-Cost Ratios for the proposed lift irrigation project at 10\% Discount Rate............................................................................. 129 
FIGURE

\section{LIST OF FIGURES}

PAGE

Figure 1-1. The study area map of the Bhairumbe/Taragod Panchayats in the Uttara Kannada District, Karnataka, India......................................................................... 11

Figure 1-2. Hydrologic Soil Group map of the study area based on ICAR soil survey data.

Figure 1-3. (a) Tiff format satellite imagery of the study area and (b) 5000 randomly generated points on top of Basemap. Source: Planetscope Imagery......................... 22

Figure 1-4. Land Use/Land Cover map of the study area.............................................. 25

Figure 1-5. Line graph showing correlation between user's accuracy with commission error and producer's accuracy with omission error of the confusion matrix ............ 28

Figure 1-6. Terrain preprocessing steps for tanks to delineate the respective catchment areas

Figure 1-7. Graph showing the linear correlation between annual rainfall and runoff..... 42

Figure 2-1. Visual representations of tanks with various attributes leading to lower performance

Figure 2-2. Visual representations of tanks with various attributes leading to higher performance

Figure 2-3. Radar diagram of the normalized values for the Irrigation Tanks with highest composite values

Figure 2-4. Radar diagram of the normalized values for the Irrigation Tanks with lowest composite values 84

Figure 2-5. Sustainability indicators and their respective weights, calculated using AHP method 86

Figure 3-1. Ownership breakdown of agricultural commodities 120

Figure 3-2. Homoscedacity of Log-Linear model with intercept 124

Figure 3-3. Homoscedasticity of Log-Linear model without intercept 124 


\section{CHAPTER 1}

\section{EVALUATION OF WATER RESOURCES IN KARNATAKA, INDIA FOR RURAL AGRICULTURE USING REMOTE SENSING AND GIS TECHNIQUES}

\subsection{INTRODUCTION}

The largest source of potential irrigation water for India is precipitation during the monsoon season that is distributed on the surface of soil and flows into surrounding bodies of water. The runoff supplies water for various thriving ecosystem types and controls irrigation decisions for agricultural land (Muthu \& Santhi, 2015). India has been experiencing a large-scale shortage of these water resources due to growing populations and increasing demand for water. The shortage also has limited the amount of water that is available for irrigation purposes. With the introduction of modern human activity, infrastructure, and growth of populations in rural areas, groundwater has become the focus of overexploitation as precipitation resources have remained constant (Abhijit et al., 2014).

The overexploitation of groundwater resources has become a controversial topic in watershed research. The exploitation has led to a decline in both the quality of water and the aquifers themselves as rate of recharge cannot keep pace with extraction. Studies regarding micro-watershed management have become increasingly important for developing approaches to mitigate factors that exacerbate surface runoff and ultimately enhance the recharge potential of the groundwater table (Abhijit et al., 2014). A watershed is defined as an area of land that diverts the entirety of its water resource 
runoff to a single common point. Watershed characteristics include features such as geology, land use, climate, slope, shape, and size.

Proper watershed management depends on the most efficient utilization of water resources in a given area with respect to all its various characteristics. One of the most commonly applied methods in watershed management is to incorporate rainfall-runoff parameters such as land use, hydrologic soil groups (HSGs), and annual precipitation for estimation of runoff (D. Ramakrishnan 2009).

Anbazhagan et al. (2005) emphasize that it is essential to estimate the available rainfall and surface runoff in a watershed. These estimations provide understanding of these key hydrological variables to prepare for the administration of artificial water recharge projects. Therefore, the estimation of surface runoff is significant for constructing our viability analysis in Chapter 3 on the proposed lift irrigation scheme in the study area for recharge of irrigation tanks. Understanding the dynamics of the watershed with regards to surface runoff will give government and community institutions a framework for constructing future irrigation projects that best fit the characteristics of the respective watershed. This framework will, in turn, benefit the social and economic development of watersheds that depend on rural agriculture. Various public and research agencies in India have made excellent progress on collecting spatial and longitudinal GIS and RS data on land cover and land use. Making use of these data and cutting-edge hydrological and computer modeling techniques, one can develop various decision-support tools that can aid resource managers and stakeholders with effective water resource development and allocation. 
Chapter 1 of my thesis research has been designed to test the availability of water resources through surface runoff estimation in a rural agricultural watershed in Karnataka, India. The data collected were analyzed using the Soil Conservation Survey Curve Number (SCS-CN) method developed by the United States Department of Agriculture and Soil Conservation Service. To achieve the necessary variables for the SCS-CN method, land use classification of rural agricultural land with three main crop types (rice paddy, areca nut, and coconut) along with water bodies, tree forests, barren land, and urban land were formulated. Furthermore, the delineated watershed characteristics of the study area will assist in ranking the hydrological attributes of the existing irrigation tanks, the leading theme of Chapter 2.

The study area falls in an agricultural watershed in Karnataka, India, where fluctuations in rainfall levels during the monsoon season have become a detriment to crop productivity. The morphology of the land in these watersheds can have a large impact on the amount of water resources that are captured in reservoirs and through infiltration of the soil layer. Being one of the largest producers of rice paddy, much of India's agricultural lands suffer from high percentages of surface runoff, as the contoured and terraced paddy land increases the runoff potential (Shwetank et al. 2010). The inconsistent rainfall and high potential for runoff have resulted in frequent drought periods. The chosen study area acts as an appropriate representation for identifying the relationship between rainfall, land cover, and soil hydrology with surface runoff.

The specific objectives of Chapter 1 focused on the evaluation of water resources are as follows: 
1. Classify and map the seven main types of land use/land cover in the study area, including: areca nut, rice paddy, coconut, water, trees, grassland, and urban surfaces.

2. Indicate the acreage irrigated and command areas of all observed irrigation tanks in the study area, with a focus on measuring surface area of rice paddy cropland that falls into the command areas for ranking in Chapter 2.

3. Calculate the relationship between watershed discharge and rainfall using the SCS-CN method.

\subsection{LITERATURE REVIEW}

\subsubsection{Application of Remote Sensing}

Remote sensing technology has advantages for data collection directly in the field as well as from a remote location outside of the area being studied. Examples of the field data (in situ) are physical measuring tools like transducers that gather data such as temperature, air humidity, and wind speed (Borengasser et al. 2008). This technique has the possibility of including error through intrusive measurements or calibration errors and is regarded as in situ ground reference data.

Ground reference data is differentiated from ground truth data as it has been given the assumption that it may contain errors (Jensen \& Shumway, 2010). In addition to field data collection, remote sensing instruments can be utilized to gather broader and often more accurate details of an area. Examples of these instruments include multispectral and hyperspectral sensors, cameras, and other detection instruments aboard satellites or aircraft (Borengasser et al. 2008).

Remote sensing can be used to facilitate water resource management from large to small scale studies. These systems provide data over large areas that can be gathered 
quickly and at low cost. Smiet (1996) utilized remote sensing to map out the vegetation and geomorphology of the overarching Uttara Kannada district in the southwest state, Karnataka, India. They established a thorough methodology for the evaluation of natural resource degradation and its effects on agricultural water resource availability. This study, along with others focusing on accuracy assessment, concluded a significant reduction in forested land and sharp rise to urban and built up areas in the past 70 years. The shift in land cover resulted in more impervious surfaces and in turn, more surface runoff (Samant \& Subramanyan 1998; Murthy \& Rao 1997).

Various remote sensing methodology has also been adopted for assessment of the inventory of irrigation structures and crop classifications in watersheds throughout the country to generate management strategies at a micro-level (Immerzeel et al. 2008). Digital classification was used from satellite imagery to categorize spectral response patterns in the Nanjur watershed located in Tamil Nadu (Hakeem \& Raju, 2009). The researchers were able to discern the distribution network and command area of irrigation structures on the basis of cropping pattern and concluded that a 4-meter multispectral resolution is sufficient for crop area mapping.

The use of satellite imagery data for agriculture can be problematic depending on seasonality when discerning different crop types on a pixel-based classification scheme. Shwetank \& Bhatia (2010) realized the technological constraint while applying the model to classifying rice paddy. Multispectral sensors had trouble distinguishing differences in absorption levels of the rice paddy versus forest land and other crops. They instead utilized various temporal hyperspectral images that allowed for the rice cover class to be 
extracted from land cover that shared similar spectral signatures, depending on the time of the year.

The repetitive nature of the satellite imagery throughout the year allows for researchers to combat the constraint depending on the type of crop land that they are focused on. Thiruvengadachari (1981) also provides an example where Landsat imagery was acquired when dryland crops would have been harvested and only irrigated crops would remain to be delineated. This research stressed the importance of crops nearing full maturity, right before harvest for the multispectral sensors to capture an accurate quantitative result (Bendix, 1976).

\subsubsection{Water Resources in Karnataka, India}

Geographic Information Systems has been utilized through multiple disciplines for spatial analysis and integration for the past 30 years, and many studies have relied on the technology as a cost-effective means of watershed management in the Southwest state of Karnataka, India (Burrough \& McDonnell., 1988).

\subsubsection{Surface Water Resources}

The National Commission for Integrated Water Resources Development has utilized GIS and other tools to estimate for the basin-wise average annual flow in river systems throughout India, which is approximately $1953 \mathrm{~km}^{3}$. Within the flow, the estimated water resource utility that could be withdrawn for agriculture, industry, and domestic uses sits at approximately $690 \mathrm{~km}^{3}$ (Kumar et al. 2005). Steps have been taken to increase the amount of water utilities through the construction of artificial recharge projects, restoration of neglected existing irrigation structures, and increased digging for water storage in suitable locations. 
Precipitation rates in Karnataka, India are highly varied both temporally and spatially with yearly fluctuation of rainfall events causing unpredictable results to surface water. Extreme hydrological events on both sides of the spectrum can induce a significant decrease in agricultural productivity which causes serious harm to the local economy in rural areas (Mall et al. 2006). These events are significant when estimating for irrigation potential of India, which is estimated to be derived from surface water (76 Mha) more so than groundwater (64 Mha) (Rupa et al. 2003). The state of Karnataka accounts for six percent of India's surface water resources with seven major river basins.

\subsubsection{Groundwater Resources}

The use of groundwater for agriculture, domestic, and industry is an invaluable natural resource that synergizes with surface water resources for human health and socioeconomic progress. India has seen vast growth of groundwater abstraction structures in the past 50 years because of improvement to technologies like electric power and diesel, along with funding from institutional finance agencies and government subsidies focused on reinvigorating the agricultural sector (Mall et al. 2006). Bore wells, open wells, and electric pump set installation has exponentially increased, allowing for more increased groundwater irrigation and larger surface area of cropland available. However, Mall et al. (2006) observed significant decline in the groundwater table in clusters of multiple districts throughout the state of Karnataka.

Not only has the state been dealing with water table shortage, but contaminants have also become introduced to the system including synthetic organic chemicals, hydrocarbons, and pathogens (Fetter, 1999). These contaminants are introduced through agricultural and industrial outlets and have been directly correlated to an estimated $80 \%$ 
of all disease in the state (Olajire \& Imeokparia, 2001). While out of the scope of our research study, GIS and remote sensing models have grown in popularity amongst researchers focused on studying groundwater contamination along with the spatial correlation of geology, land use and pollution sources (Nas \& Berktay 2010; Hudak \& Sanmanee 2003).

\subsubsection{Domestic Water Use}

For domestic purposes in India, roughly $7 \mathrm{~km}^{3}$ of surface water and $18 \mathrm{~km}^{3}$ of groundwater are implemented into the community water supply for both urban and rural areas, while domestic water use only accounts for $5 \%$ of the total water resources (Kumar et al., 2009). Consumptive uses of domestic water resources include drinking, health, and sanitation. Domestic water use was shown to induce significant wastage, where both nondomestic and domestic per capita wastage is measured at 140 liters per day (Suryakanth \& Mulgund, 2017). Estimations of population growth of Karnataka by 2050 have been projected at 59.90 million for rural areas and the per capita water requirement for these areas is currently 150 liters per day. These estimations reveal a large gap with the lack of infrastructure for this population size with rainfall storage and river water resource allocation (Kumar et al. 2009).

\subsubsection{Agricultural Water Use}

Statistics across India show that the agricultural sector is the leading consumer of water resources, where approximately $83 \%$ of existing resources are allocated. Mall et al. (2006) explains that in order to meet the rising future demand for crops, there is a necessity for enhancing the allocation of existing resources. This enhancement includes the development of new sources of water along with introducing additional water flow to 
existing irrigation sources. Lakes and tanks serve both agricultural and domestic demand, with roughly 37,000 spread over Karnataka and the trends for gross irrigated area percentage in the command areas of these tanks has slowly risen between 1980 and 2015 (Raj \& Chandrakantha, 2015).

\subsubsection{SCS-CN Runoff Estimation Model Integration}

Researchers have been integrating GIS and remote sensing to run the SCS-CN model on watersheds of various topographic, elevation, and size characteristics. The SCS-CN model is the most commonly used method in application of surface runoff estimation due to its relative simplicity and set of consistent parameters. SCS-CN was created by the United States Department of Agriculture and Soil Conservation in 1972 to estimate surface runoff. Muthu \& Santi (2016) utilized SCS-CN in Tamil Nadu when assessing the surface runoff of the Kancheepruam District. They utilized their study to offer alternate cropping pattern regime shifts, as well as providing water conservation measures in including implementation of terraces, diverting channels, and adding recharge pits.

Pal \& Samanta (2011) added the dimension of remote sensing to the SCS-CN model, as satellite imagery can be necessary for land cover classification in the absence of secondary data sources. Their study found high runoff in the respective river basin and correlated the maximum runoff with soil erosion and areas of low infiltration rates. Furthermore, Rao et al. (2010) explained the rate of infiltration in depth by utilizing the parameter of HSGs. These are defined by the morphology of the soil and the potential for water to enter the specific soil surface. They were able to extract the percentage of total 
runoff between 1997 and 2006, which expressed the amount of water resources that could have been used for utility but were ultimately lost from the system.

\subsection{METHODOLOGY}

Our study focuses on multiple hydrological parameters that have been identified using remote sensing and GIS software. These parameters are then utilized to calculate surface runoff and hydrological performance of 40 irrigation tanks in the study area. The location and general information of the irrigation tanks were retrieved from the local governing body (Panchayat) office. The data provided on the tanks were not comprehensive, as some tanks could not be located due because of a variety of factors including complete siltation or encroachment by cropland.

The study scope is limited to a small agricultural watershed in Karnataka, India that is experiencing fluctuations in rainfall and loss of groundwater leading to considerable crop yield loss. These methods will assist us is assessing the current status of water resource availability through the SCS-CN model along with characterization of tanks for restoration purposes.

\subsubsection{Study Area}

The Bhairumbe \& Taragod Panchayats (Figure 1-1) watershed covers roughly 60 square kilometers and is located between 14²41'29.69" $\mathrm{N}$ and $74^{\circ} 46^{\prime} 57.78^{\prime \prime} \mathrm{E}$ in the central portion of the Western Ghats. The Western Ghats region has been hailed as one of the most prominent biodiversity hotspots in the world. As a consequence of climate change and overexploitation of ecosystem services, conservation efforts in this area are becoming increasingly crucial (Kerr, 2002). The Western Ghats mountain range has 
experienced a $40 \%$ reduction of forest cover since the 1900s, and the reduction has been attributed to the national and regional policies that fuel agricultural development (Helmut et al. 2002).

Figure 1-1. The study area map of the Bhairumbe/Taragod Panchayats in the Uttara Kannada District, Karnataka, India

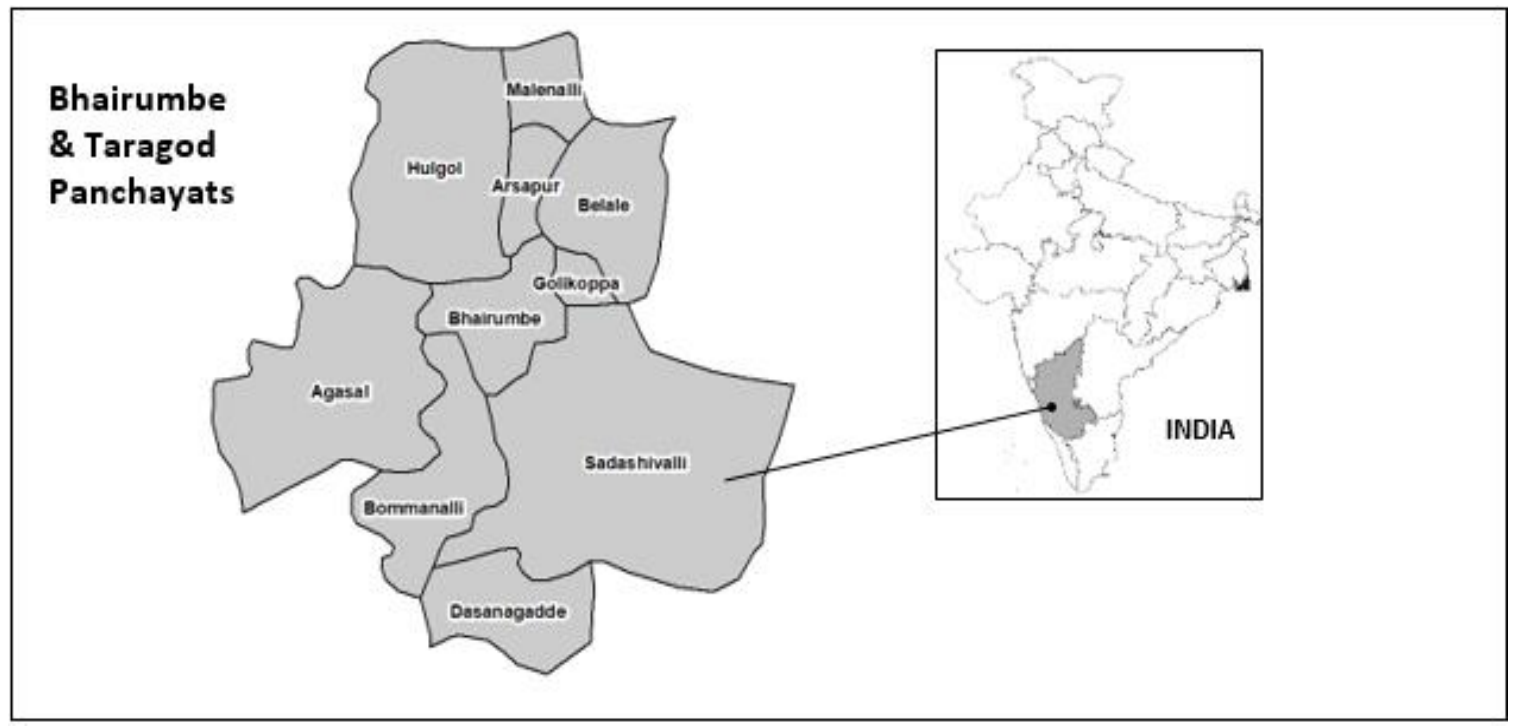

The Bhairumbe/Taragod Panchayats consist of fluctuating topography with an elevation of roughly 2000 feet above sea level. It is a mountainous region formed by valleys and small hills with slopes ranging from moderate to gentle (Sundarapandian \& Swany, 2015). Land use regime shifts are taking place in the area in favor of less water demanding crops, but the current land cover patterns include state-owned forestlands, Soppina betta forests, cultivated land streams, habitation, roads, and tanks.

The study Panchayats include ten farming villages that rely on irrigation from tanks and the Shalmala River that meanders across the east border. The primary occupation of the local people in this area is agricultural, with a diversified range of 
products including horticulture crops, legumes, vegetables, fruits, ornamentals, and flowering plants. Agroforestry is the traditional function of land use in the area and provides food security and production for the livelihood of the households. Throughout the present paper, water resources including rivers, streams, and tanks of the Bhairumbe/Taragod Panchayats are the focus for the conservation of traditional agricultural techniques along with the preservation of livelihoods.

\subsubsection{Land Use Data/Variable Selection}

Due to the rural nature of the study site and lack of land use data, the present research will focus predominantly on the mapping of three crops: coconut, areca nut, and rice paddy, along with the lesser significant classes of trees, barren land, urban land, and water. Land classes will be delineated from each other to detect the present status and morphology of the study site. Satellite images with $3.9 \mathrm{~m}$ spatial resolution were taken from the Planetscope satellite.

Geometric corrections were unnecessary because the imagery was georectified by the Planetscope imagery service. Images with little percentage of cloud cover and full coverage of the study area were extracted in appropriate seasons for delineating crop type, and a set of randomly generated training points were input onto the raster image (Rao et al., 2010). A set of variables and sources used in this study can be found in Table $1-1$. 
Table 1-1. Climate variables, topographical maps, and satellite imagery for surface runoff modeling

\begin{tabular}{cccc}
$\begin{array}{c}\text { Climate } \\
\text { Variables/Satellite } \\
\text { Imagery }\end{array}$ & $\begin{array}{c}\text { Scale/Data } \\
\text { Resolution }\end{array}$ & Year & Source \\
\hline Rainfall & - & $2009-2017$ & $\begin{array}{c}\text { Government of } \\
\text { Karnataka Water } \\
\text { Resource }\end{array}$ \\
& & & Department \\
Digital Elevation & $30 \mathrm{~m}$ & 2015 & https://bhuvan- \\
Model & $3.9 \mathrm{~m}$ & & appl.nrsc.gov.in \\
Planetscope & & 2017 & Planet Imagery and \\
Satellite Imagery & & & Archive \\
& $1: 250000$ & 1976 & National Bureau of \\
Soil map of Uttara & & Soil Survey, \\
Kannada District & & & Bangalore
\end{tabular}

\subsubsection{Resolution}

A spatial resolution of $3.9 \mathrm{~m}$ is appropriate for identification of crop classes and water bodies. Furthermore, for the irrigation tanks, the radiometric resolution of the chosen satellite imagery must be 12 bits to differentiate the smaller fields and structures (Makin et al. 2000). For temporal resolution, rice paddy is fully matured around the end of May with a reflectance behavior range of 530-1640 nm.

Areca nut bears its fruit 5 years after planting between September and October with a reflectance behavior range of $460-910 \mathrm{~nm}$. Coconut trees are perennial crops that produce fruit year-round, at a range of 700-920 nm (Bhojaraja et al. 2015). Two raster 
images were layered from peak dry season in April and peak rainy season in January to best distinguish rice paddy versus barren land.

\subsubsection{Algorithm Selection}

Table 1-2 shows the land cover classes that were utilized for mapping and the training polygons that were chosen using ground referenced area and key informant analysis (Jasrotia et al. 2009; Rao et al. 2010). Using Pal \& Samanta (2011) as a supplement, the data were then run through the maximum likelihood classification algorithm, which was a supervised classification tool that generated land use/land cover codes using pixel density and values.

Table 1-2. Land Cover/Land Use Classes

\begin{tabular}{|c|c|}
\hline Class No. & Land use/Land cover \\
\hline 1 & Coconut \\
\hline 2 & Trees \\
\hline 3 & Barren Land \\
\hline 4 & Urban \& Built-up \\
\hline 5 & Rice Paddy \\
\hline 6 & Water \\
\hline 7 & \\
\hline
\end{tabular}

\subsubsection{Accuracy Assessment}

Following recommendations from Olofsson (2014), a stratified random sampling design was utilized to allow for an appropriate sample size for certain classes that might only cover an insignificant portion of the whole area, such as water resources in the 
Bhairumbe/Taragod Panchayat. Because of the size of the study area, the spatial unit for the reference classification versus the map classification was chosen as a pixel. Ground visits to the study area along with ultra-high spatial resolution from Google Earth Pro were used in combination as the sources for reference material, as a result of the continuous nature of the land cover. Sample size for each individual land class was derived from Congalton and Green (2009) in which a multinomial distribution equation is used to ascertain the accuracy of the thematic elements of the map. Equation 1-1 was used to determine sample size $(N)$ :

$$
N=\frac{B \Pi_{i}\left(1-\Pi_{i}\right)}{b_{i}^{2}}
$$

$\Pi_{i}$ is the proportion of the $i$ th land cover class out of $k$ number of classes that most closely represents a $50 \%$ proportion of all the classes on the map, $b_{i}$ is the specific precision that is being measured, and $B$ is determined by the chi square distribution, $\frac{\alpha}{k}$, with 1 degree of freedom.

Analysis was then done on the error matrix to cross-tabulate the allocated labels versus the referenced labels, and an estimation for accuracy was calculated for each land class at a $95 \% \mathrm{CI}$ at $2 \%$ precision. Aside from overall accuracy, user's accuracy (commission error) and producer's accuracy (omission error) were calculated. 


\subsubsection{Soil Characteristics}

The impervious surfaces introduced by urban areas and agricultural manipulation of the land has changed the way that rainfall reacts with the surface of the earth. Soil type and texture has influence for determining the soil group of a given area. The types of soils are expressed by the smaller fractions of particles such as sand, silt, and clay that form the soil surface (Rolland \& Rangarajan, 2013).

Soil types are also categorized into HSGs, which vary in their potential for infiltration after prolonged rainfall. The United States Department of Agriculture has classified HSGs into four main groups defined by their infiltration rate capabilities (USDA Hydrology National Engineering Handbook 2007). Table 1-3 shows an overview of the four distinct groups and their respective soil types, along with the area of individual HSGs that fall into the study area.

Table 1-3. USDA-SCS Soil Classification Scheme

\begin{tabular}{ccc}
\hline HSG & Soil Type & Runoff Potential \\
\hline Group A & $\begin{array}{c}\text { Deep, well drained gravel and } \\
\text { sand with high infiltration } \\
\text { Goderately deep, well drained } \\
\text { with moderate infiltration }\end{array}$ & Low \\
Group C & $\begin{array}{c}\text { Clay loam, shallow sandy } \\
\text { loam with low infiltration }\end{array}$ & Moderate \\
Group D & $\begin{array}{c}\text { Clay soils with very low } \\
\text { infiltration }\end{array}$ & High \\
\hline
\end{tabular}

\subsubsection{Drainage of Irrigation Tanks}

The direction of flow found in the study area was identified to run from south-east to north-west, with the main river, the Shalmala River, being predominantly fed by 
precipitation in the monsoon season. The length of the river through the study is $9 \mathrm{~km}$ and is the primary source for both religious and ecosystem services. The river provides groundwater recharge along with possibilities for construction of irrigation projects to optimize its water resources for local agriculture.

The study area is too small to have a significant drainage map, with only four orders available from the stream order delineation process using ArcHydro tools in ArcGIS. Following Pareta \& Pareta (2012) and Sharma et al. (2015), the digital elevation model of the study area was inputted and processed to extract flow direction, flow accumulation, stream definition, and drainage lines. These were essential processes for the model in order to delineate the necessary watershed points. The batch point watershed tool was then used to obtain the surface area of land that falls within the command area of each of the 40 individual irrigation tanks. Batch points act as the point of separation between catchments and can be input along any drainage line of interest, where they delineate the overall area that flows into each specific outlet. These values will be ranked on the basis of size of crop acreage irrigated and other characteristics later in Chapter 2.

\subsubsection{Rainfall}

To complete the objectives of the of the project, rainfall data for the years 20092017 were collected from the Government of Karnataka Water Resources Department, Bangalore Gauging Sub-division no. 2, Dharwad. Rainfall was available in millimeters measured at 8:30 AM daily from coordinates $14^{\circ} 39^{\prime} 52.56^{\prime \prime} \mathrm{N}, 74^{\circ} 50^{\prime} 2.4^{\prime \prime}$ E to represent the study area. Table 1-4 presents the yearly total rainfall. 
Table 1-4. Yearly recorded rainfall data for the Bhairumbe/Taragod Panchayats, Taragod Station

\begin{tabular}{cc} 
Year & Rainfall (mm) \\
\hline 2009 & 2347 \\
2010 & 2189 \\
2011 & 2798 \\
2012 & 1869 \\
2013 & 2587 \\
2014 & 2728 \\
2015 & 1863 \\
2016 & 1428 \\
2017 & 2868 \\
\hline Total & $\mathbf{2 0 6 7 7}$
\end{tabular}

Source: Government of Karnataka Water Resources Department, Bangalore, Gauging sub-division no. 2, Dharwad.

\subsubsection{Curve Number Estimation}

The identification of curve numbers for runoff estimation was originally developed using empirical analyses by the USDA on runoff in small hillslopes and catchments (SCS, 1985). Curve number utilizes rainfall, hydrologic soil group, and land use to indicate a value ranging from 0 to 100 . Smaller $\mathrm{CN}$ values express a lower runoff potential while larger values have a higher potential, depending on the permeability of the soil (Hawkins et al., 2009). Furthermore, the hydrologic curve number for the study area watershed is based on antecedent moisture condition (AMC)-II. 
McCuen (1982) defines AMC as having three different soil moisture content conditions before a storm event of interest, defined by the preceding 5-day period. Antecedent Moisture Condition II is considered the standard condition of average direct runoff that is commonly calculated first and used to find $\mathrm{CN}$ values for AMC-I and AMC-III. Table 1-5 gives value classification to seasonal antecedent moisture conditions (Ambazhagan et al., 2005; Jasrotia \& Singh, 2006; Rao \& Narendra, 2006).

Table 1-5. Values of antecedent moisture conditions based on seasonality and 5-day antecedent rainfall patterns

\begin{tabular}{ccc}
\hline AMC Value & $\begin{array}{c}\text { Dormant season } \\
\text { rainfall }(\mathbf{m m})\end{array}$ & $\begin{array}{c}\text { Growing season } \\
\text { rainfall }(\mathbf{m m})\end{array}$ \\
\hline I & Less than 13 & Less than 35 \\
II & $13-28$ & $35-53$ \\
III & Greater than 28 & Greater than 53 \\
\hline
\end{tabular}

Source: (McCuen 1982)

The $\mathrm{CN}$ is described in the SCS-CN equation by representing the potential maximum retention after runoff starts, which is related to soil and land cover conditions. The weighted curve number from all HSG and land cover variables in the study area is given by,

$$
C N=\sum_{i=1}^{n} \frac{C N_{i} \times A_{i}}{A_{i}}
$$

where the weighted curve number $(C N)$ is found from number of classes $(n)$, the individual curve numbers for each land use and HSG combination $\left(C N_{i}\right)$, and the area of 
land under each land use and HSG combination $\left(A_{i}\right)$. The $\mathrm{CN}$ is then implemented into the potential maximum retention equation for AMC-II (CNII) (Rao et al., 2010). The modified equation for potential maximum retention $(\mathrm{S})$ is as follows:

$$
S=\frac{25400}{C N I I}-254
$$

Chow (1964) explains that the weighted curve number result for AMC-II can then be applied for $\mathrm{CN}$ values of AMC-I and AMC-III using the following formulas:

$$
\begin{gathered}
C N I=\frac{4.2 \times C N I I}{10-(0.058 \times C N I I)} \\
C N I I I=\frac{23 \times C N I I}{10+(0.13 \times C N I I)}
\end{gathered}
$$

\subsubsection{Surface Runoff Estimation}

Once the $\mathrm{CN}$ and $\mathrm{S}$ parameters have been calculated, the next step is to estimate for the direct runoff from the watershed. The SCS-CN equation is as follows:

$$
Q=\frac{\left(P-I_{a}\right)^{2}}{\left(P-I_{a}\right)+S}
$$


Following Narayana (2002), the initial abstraction $\left(I_{a}\right)$ is the loss before runoff begins, which is $I_{a}=0.3 S$ for Indian condition and $\mathrm{P}$ is the total storm rainfall measured in $\mathrm{mm}$. The modified equation utilized in the study to estimate for actual direct runoff in $\mathrm{mm}(\mathrm{Q})$ is shown below.

$$
Q=\frac{(P-0.3 S)^{2}}{(P+0.7 S)}
$$

\subsection{RESULTS AND DISCUSSION}

\subsubsection{Soil Data}

The soils found in the study area include deep, well-drained and moderately welldrained, clayey soils on laterite planes, isolated hills, and valleys. The major soils found here are (1) fine, kaolinitic, Kandic Paleustalfs (2) clayey-skeletal, kaolinitic, Oxic Ustropepts (3) fine-loamy, mixed, Aquic Ustropepts and (4) clayey, kaolinitic, Ustic Kandihumults. These soil types have been categorized into respective hydrologic soil groups in Table 1-6 and mapped out in Figure 1-2. These results were gathered from the Indian Council of Agriculture Research (ICAR).

Table 1-6. Soil types and their corresponding HSG value and extent in the study area

\begin{tabular}{cccc}
\hline $\begin{array}{l}\text { SL. } \\
\text { No. }\end{array}$ & Soil Type & HSG & $\begin{array}{c}\text { Sq. } \\
\text { Km. }\end{array}$ \\
\hline 1 & Fine, Kaolinitic, Kandic Paleustalf & B & 30 \\
2 & Clayey-Skeletal, Kalinitic, Kanhaplic, Haplustalf & B & 26 \\
3 & Fine, Loamy, Mixed Aquic Ustropept & D & 4 \\
4 & Clayey Kaolinitic Ustic Kandihumult & D & 0.05 \\
\hline
\end{tabular}

Source: Indian Council of Agriculture Research (ICAR) 
Figure 1-2. Hydrologic Soil Group map of the study area based on ICAR soil survey data

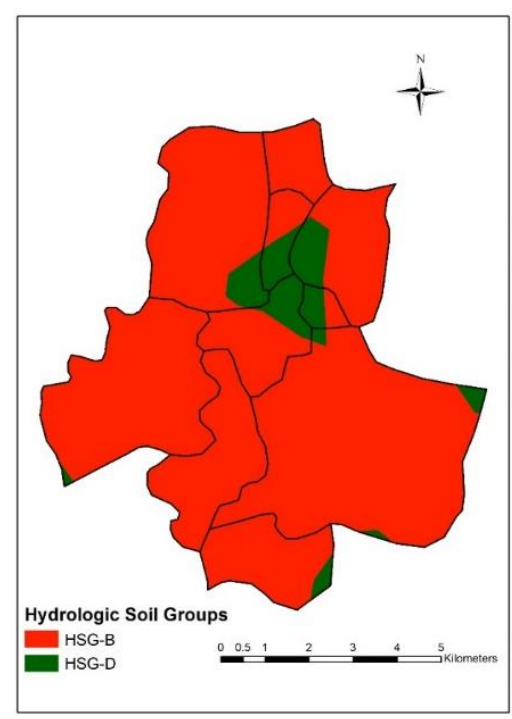

\subsubsection{Land Cover/Land Use Mapping}

Five thousand random points were generated in ArcMap 10.5 across the study area as seen in (b) of Figure 1-3. These points were then classified depending on the land

Figure 1-3. (a) Tiff format satellite imagery of the study area and (b) 5000 randomly generated points on top of Basemap. Source: PlanetScope Imagery

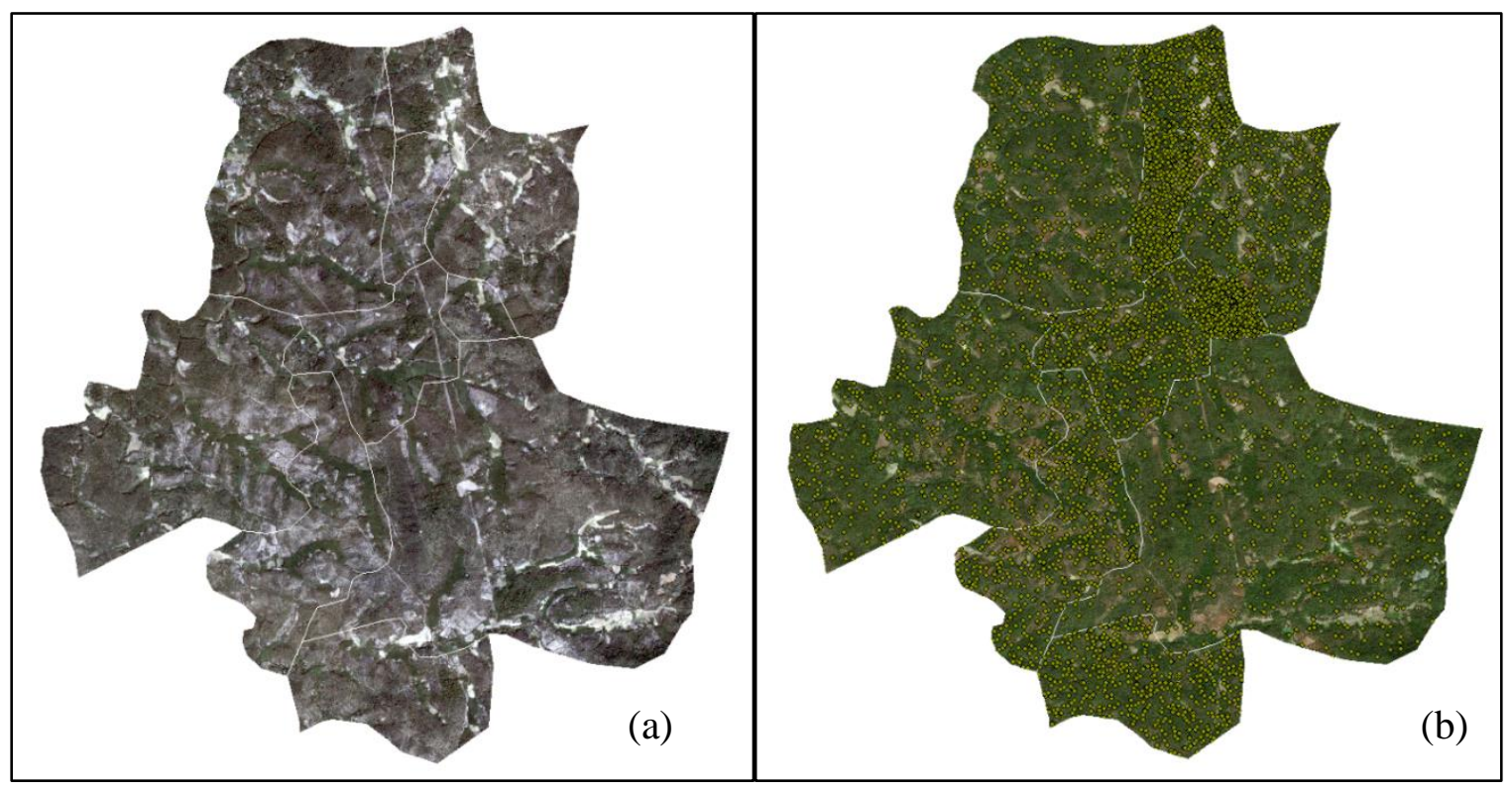


cover/land use of which they fell. The large set of points allowed for a diverse sample that covered the entire study area and covered all the necessary land use classes. Once all the points had been properly identified and referenced, they were then input as training samples into the maximum likelihood classification tool in ENVI 5.5 to construct the final land use/land cover map in both raster and vector format.

The Planetscope satellite image in (a) of Figure 1-3 was also used as the raster file for which the likelihood classification tool would interpret the pixels. The image was constructed of stacked images from April 2017 (end of dry season) and one from January 2017 (end of monsoon season) and merged together to have eight bands that allow for more accurate delineation of the different land classes (Hakeem \& Raju, 2009). The spectral signatures of the crop classes were able to be better differentiated with the raster stack, especially rice paddy, as its morphology is akin to a wetland during the dry season, while areca nut and coconut are perennial plantation crops.

Figure 1-4 gives a thematic look at the final land use/land cover map constructed through ArcMap and ENVI. At first glance, the maximum likelihood classification tool looks as if it did an accurate job in giving all seven classes the correct pixel values. Some noise is shown, mostly in the areas of dense tree forests, which leads us to conclude that the $3.9 \mathrm{~m}$ resolution might have had too many pixel values that covered a wider range than expected. The map accurately portrays the Shalmala River network running from south to north on the west side of the study area and gives a good visual to the cropping patterns of areca nut, rice paddy, and coconut farming.

While all 40 irrigation tanks were ground referenced and mapped out, the likelihood classification analysis was unable to delineate the smaller tanks with an area of 
less than $1000 \mathrm{~m}^{2}$. Other reasons for the inability to delineate these tanks could have resulted from a significant portion of these smaller scale tanks being covered by canopy, as well as the pixel values being smoothed over during kernel post classification processing. Table 1-7 is derived from the land cover map to express the distribution of the different land cover classes in square kilometers. The data were extracted from the output vector file attribute table, where the area was calculated with the "calculate geometry" tool and then finding the sum for each class using the "statistics" tool. With this distribution of land area, it was possible to reference the validity of the output raster map using a confusion matrix. 
Figure 1-4. Land Use/Land Cover map of the study area

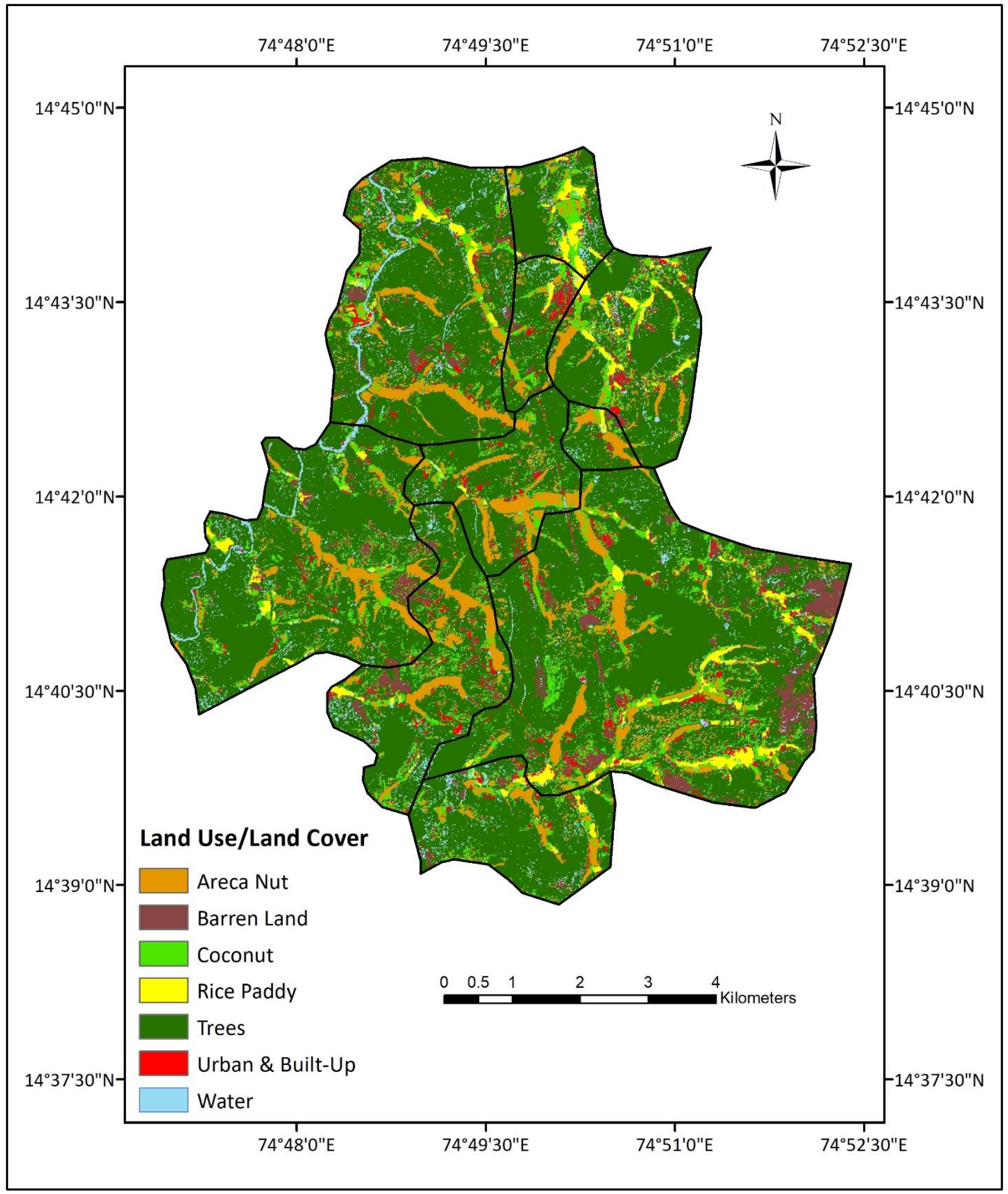


Table 1-7. Surface area of land use/land cover classes in the Bhairumbe/Taragod Panchayat area

\begin{tabular}{|c|c|c|c|}
\hline Class No. & $\begin{array}{c}\text { Land use/Land } \\
\text { cover }\end{array}$ & Area in sq. km & Area in \% \\
\hline 1 & Areca Nut & 9.6 & 16 \\
\hline 2 & Barren Land & 4.2 & 7 \\
\hline 3 & Coconut & 2.4 & 3 \\
\hline 4 & Rice Paddy & 1.8 & 63 \\
\hline 5 & Trees & 37.8 & 2 \\
\hline 6 & Urban \& Built-Up & 1.2 & 5 \\
\hline 7 & Water & 3 & $\mathbf{6 0}$ sq. $\mathbf{k m}$ \\
\hline
\end{tabular}

The Bhairumbe/Taragod study area consists of a seven different land covers that cover a very wide range of area. Of the $60 \mathrm{~km}^{2}, 63 \%$ of the area is covered by dense tree forests, $16 \%$ by areca nut, $7 \%$ by barren and fallow land, $3 \%$ by rice paddy, $4 \%$ by coconut, $5 \%$ by water, and $2 \%$ by urban area. The thematic map in Figure 1-4 was generated in ArcGIS and expresses the land cover for both dry and rainy periods in 2017. The map can also be utilized for change detection for loss of vegetation and agricultural land over a set period if satellite images from different years are run through the maximum likelihood classification process. For now, the distribution of land cover will assist us in multiple objectives, including finding the surface runoff and prioritizing the irrigation tanks in the watershed in Chapter 2. 


\subsubsection{Confusion Matrix for Land Cover/Land Use Classification}

Equation 1-1 was used to find the $N$ number of sampling points and is evaluated using the land class of trees as the $\Pi_{i}$ value, as the proportion of this class falls closest to $50 \%$ of the overall land at approximately $63 \%$. The study area has seven distinct classes $(k=7)$, which are used in the calculation to find the upper $100^{\text {th }}$ percentile of the chisquare value. With $95 \%$ confidence at $5 \%$ precision, the equation is the following:

$$
B=1-\frac{\alpha}{k}=1-\frac{0.05}{7}=0.99286
$$

With 1 degree of freedom: Chi-square critical value $(B)=7.23$. Furthermore, the $N$ value results in,

$$
N=\frac{B \Pi_{i}\left(1-\Pi_{i}\right)}{b_{i}^{2}}=\frac{7.23(0.63)(1-0.63)}{0.05^{2}}=665 \text { Samples }
$$

\begin{tabular}{|c|c|c|c|c|c|c|c|c|}
\hline $\mathrm{N}=665$ & Actual & & & & & & & \\
\hline Predicted & $\begin{array}{l}\text { Areca } \\
\text { Nut }\end{array}$ & $\begin{array}{l}\text { Barren } \\
\text { Land }\end{array}$ & Coconut & $\begin{array}{l}\text { Rice } \\
\text { Paddy }\end{array}$ & Trees & Urban & Water & $\begin{array}{l}\text { Grand } \\
\text { Total }\end{array}$ \\
\hline $\begin{array}{l}\text { Areca } \\
\text { Nut }\end{array}$ & 78 & 0 & 16 & 0 & 0 & 1 & 0 & 95 \\
\hline $\begin{array}{l}\text { Barren } \\
\text { Land }\end{array}$ & 0 & 78 & 0 & 14 & 0 & 3 & 0 & 95 \\
\hline Coconut & 12 & 0 & 75 & 0 & 8 & 0 & 0 & 95 \\
\hline $\begin{array}{l}\text { Rice } \\
\text { Paddy }\end{array}$ & 0 & 8 & 0 & 86 & 0 & 1 & 0 & 95 \\
\hline Trees & 4 & 0 & 0 & 0 & 91 & 0 & 0 & 95 \\
\hline Urban & 0 & 14 & 0 & 0 & 0 & 81 & 0 & 95 \\
\hline Water & 0 & 0 & 0 & 0 & 3 & 15 & 77 & 95 \\
\hline $\begin{array}{l}\text { Grand } \\
\text { Total }\end{array}$ & 94 & 100 & 91 & 100 & 102 & 101 & 77 & 665 \\
\hline
\end{tabular}

Table 1-8. Confusion matrix of 7 land use classes using a sample size of 665

In Table 1-8, the sample size found with Equation 1-1 is divided seven ways and gives 95 randomly generated resampling points to each land class. Following Jensen and 
Shumway (2010), we used a stratified random sampling method to introduce randomness to the reference points but allowed for each land class to have an equal amount of points. These points were then referenced from Google Earth Pro, key informants, and the Tiff file image to compare with the predicted pixel values that were given using the maximum likelihood classification tool.

As can be derived from the error matrix, the total accuracy of the land use/land cover map was $85.11 \%$ after summing the actual values that matched with predicted values of the classification method and dividing by the total amount of samples. It is possible that a higher accuracy could have been achieved if more sample locations had been determined during ground reference visits to the geographic locations of the points in the study area.

Figure 1-5. Line graph showing correlation between user's accuracy with commission error and producer's accuracy with omission error of the confusion matrix

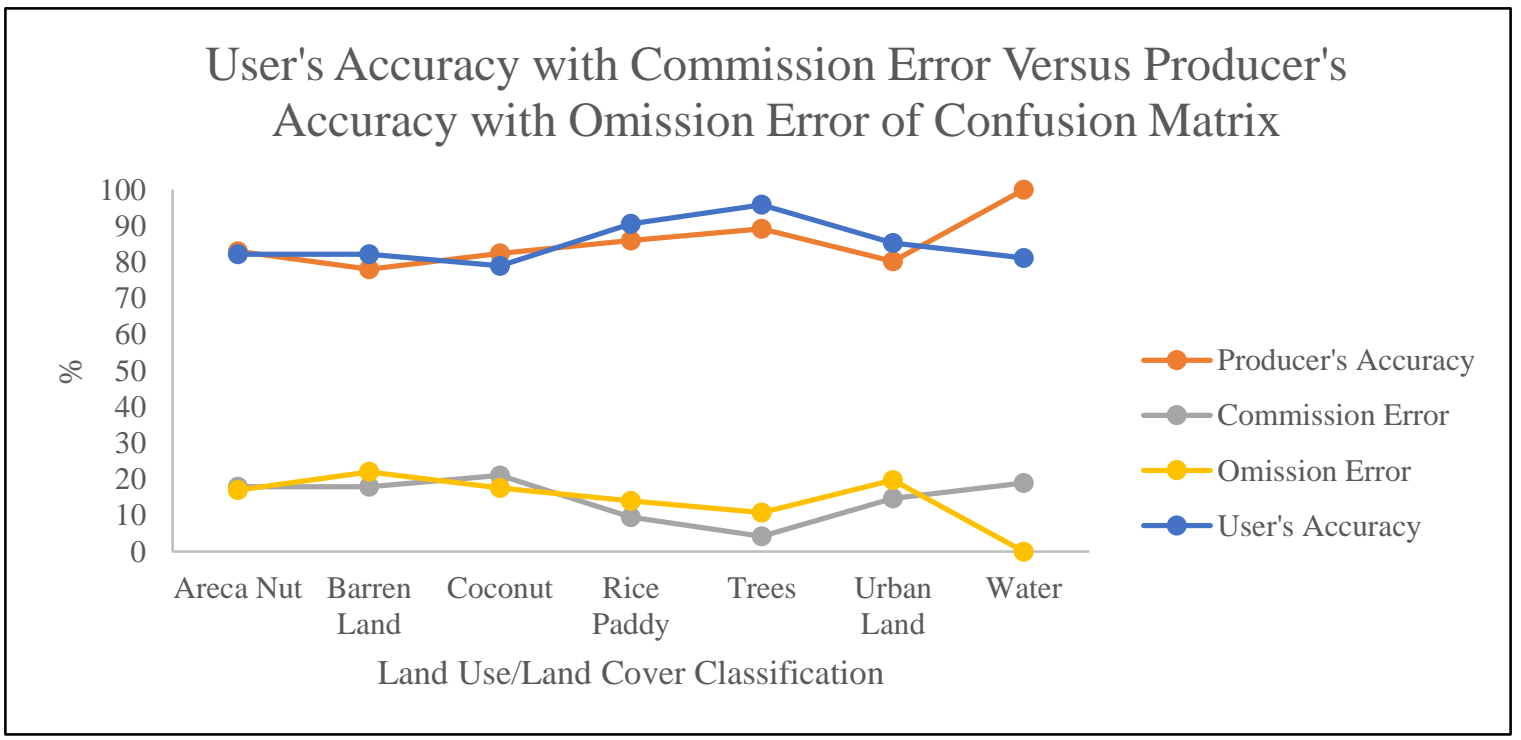

In addition to overall accuracy, the producer's accuracy and the user's accuracy have also been calculated. Figure 1-5 shows a linear trend between how well the area was 
classified and the probability that the pixel on the map represents the predicted category given. The producer's accuracy of trees was much lower than the user's accuracy because of the many of the other land classes being confused for this specific class. The accuracy of trees could be a result of the sheer proportion of the trees class compared with the other six classes that gave it a sort of dominance over the study area. Figure 1-5 also expresses the differences in accuracy, defined as commission and omission errors.

Commission error refers to the percent of pixels from the user's accuracy that were added to the land cover class, while omission error is the percent of pixels from the producer's accuracy that were taken from a land cover class and distributed to other classes.

\subsubsection{Irrigation Tank Command Area Delineation}

The delineated drainage command area was obtained for each of the 40 irrigation tanks following procedures of the ArcHydro tools in ArcMap 10.5. Figure 1-6 shows the ArcHydro process, where the digital elevation model (a) of the study area is the source for terrain preprocessing of water resources. The flow direction (b), flow accumulation (c) and drainage lines (d) are all attained in order to calculate for batch watershed delineation of the tanks. The batch points (d) were attached to the top of the outflow stream, where the water from the irrigation tank heads towards the higher stream orders. The flow direction was adjusted for the tanks by characterizing them as lakes, and then inputting this updated flow direction into the batch point watershed delineation tool. The output results of the tool gave the overall acreage in the command area of each of the tanks.

When delineating each command area, we observed from the flow accumulation layer that that Shalmala River is the highest stream order where the flow from all the 
irrigation tank locations is fed, moving rainfall and runoff from the southwest of the study area through the northwest. To get individual command areas rather than higher stream order flow, the batch points had to be input usually on a single drainage line that connected the irrigation tank area to the rest of the streams.

Table 1-9 shows the range of the watershed acreage, mostly as result of large variations in size, volume, and shape between the tanks. The area includes all seven of the land use classifications shown in Figure 1-3 and is further divided into purely crop area acreage that falls into each command area. The crop land use classes were extracted from the full command areas of each tank in ArcMap and then the statistics tool was used to calculate for area in acreage. The potential attribute of ranking tanks was finally constructed for prioritization based off the number of crops that they irrigate.

To continue logical consistency, the crop acreage of the irrigation tanks was multiplied by the $85.11 \%$ accuracy rating of the land use map utilized for this delineated result. The same accuracy will not be considered for measuring land cover for the surface runoff calculation, as other studies on surface runoff have utilized the data provided by their individual land cover maps regardless of accuracy percentage for estimating the curve number of an area (Im et al. 2007; Muthu et al. 2015; Pancholi et al. 2015).

Of the 40 irrigation tanks, the ones with the highest overall command areas consistently had a higher percentage of crop area. Farmers have taken advantage of the sub-watershed catchments to capture rainfall runoff as sheet flow for their crops in the monsoon season and urban settlements and communities are usually located in these stream outlets. 
Figure 1-6. Terrain preprocessing steps for tanks to delineate the respective catchment areas
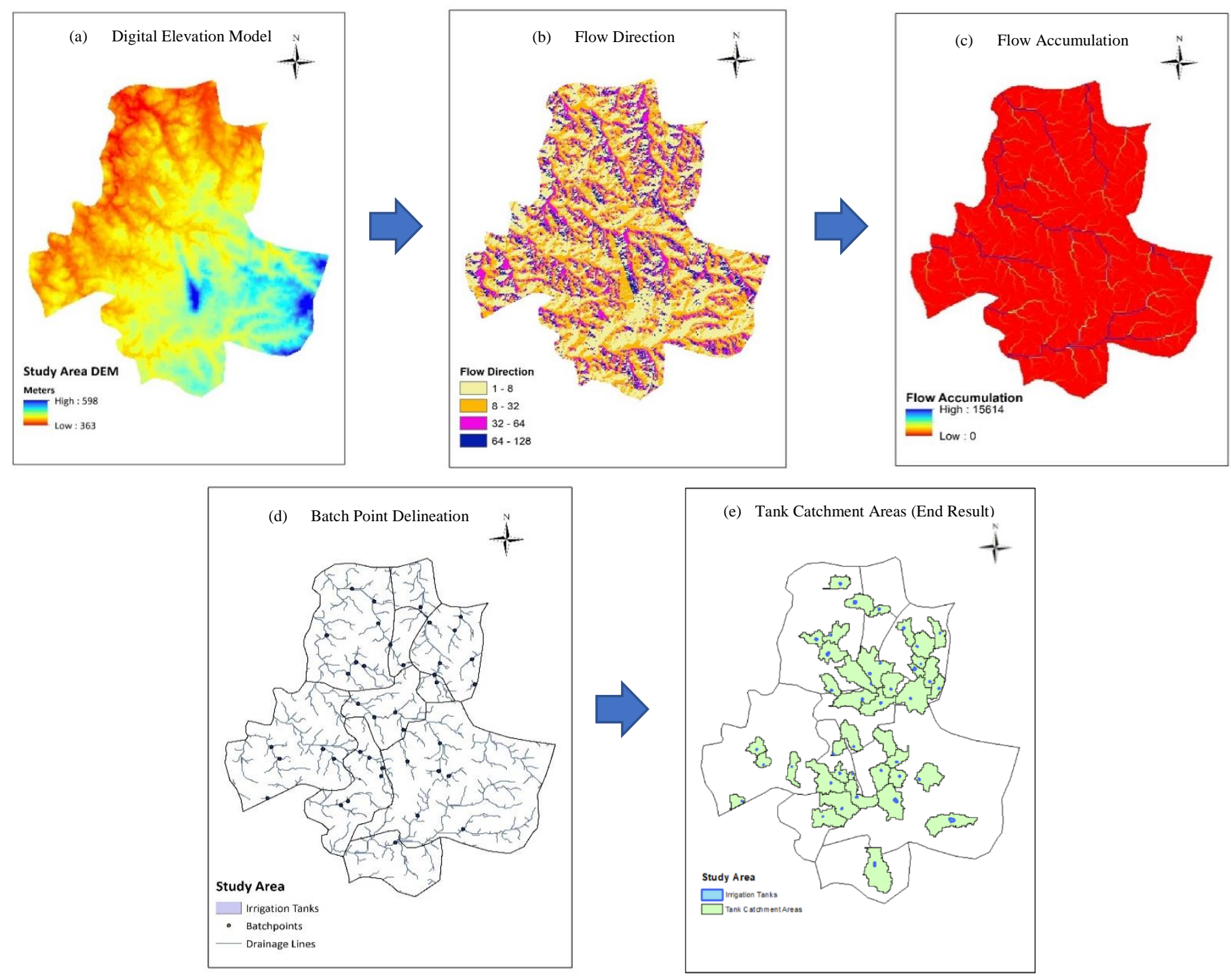
Table 1-9. Overall command area and crop acreage irrigation (85.11\% accuracy) by the 40 irrigations tanks

\begin{tabular}{|c|c|c|c|c|}
\hline \multirow[t]{2}{*}{ SL No. } & \multirow[t]{2}{*}{ Irrigation Tank } & \multirow[t]{2}{*}{$\begin{array}{c}\text { Overall } \\
\text { Watershed } \\
\text { Area (Acres) }\end{array}$} & Crop & area \\
\hline & & & Acres & $\%$ \\
\hline 1 & $\begin{array}{c}\text { Gadigehole } \\
\text { Tank }\end{array}$ & 43 & 5.11 & 12 \\
\hline 2 & Ashisara Tank & 99 & 19.58 & 20 \\
\hline 3 & $\begin{array}{c}\text { Moolimane } \\
\text { Nidagod Tank }\end{array}$ & 65 & 11.92 & 18 \\
\hline 4 & Ambalike Tank & 211 & 29.79 & 14 \\
\hline 5 & $\begin{array}{c}\text { Kathlehalla } \\
\text { Tank }\end{array}$ & 156 & 43.41 & 28 \\
\hline 6 & Taragod Tank & 169 & 36.60 & 22 \\
\hline 7 & $\begin{array}{c}\text { Bommanalli } \\
\text { Tank }\end{array}$ & 110 & 22.13 & 20 \\
\hline 8 & $\begin{array}{c}\text { Kadave \#1 } \\
\text { Tank }\end{array}$ & 168 & 37.45 & 22 \\
\hline 9 & $\begin{array}{c}\text { Kadave \#2 } \\
\text { Tank }\end{array}$ & 127 & 21.28 & 17 \\
\hline 10 & Nidagod Tank & 117 & 12.77 & 11 \\
\hline 11 & $\begin{array}{c}\text { Anchigadde } \\
\text { Tank }\end{array}$ & 64 & 11.92 & 19 \\
\hline 12 & Chowdi Tank & 99 & 17.02 & 17 \\
\hline 13 & $\begin{array}{c}\text { Kelagina } \\
\text { Bommanalli } \\
\text { Tank }\end{array}$ & 120 & 26.38 & 22 \\
\hline 14 & Konkana Tank & 5 & 11.92 & 23 \\
\hline
\end{tabular}




\begin{tabular}{|c|c|c|c|}
\hline 15 & $\begin{array}{l}\text { Bugadimane } \\
\text { Tank }\end{array}$ & 168 & 45.11 \\
\hline 16 & Kibbali Tank & 67 & 25.53 \\
\hline 17 & Ashimane Tank & 41 & 7.66 \\
\hline 18 & Halige Tank & 37 & 3.4 \\
\hline 19 & $\begin{array}{c}\text { Devari Keri } \\
\text { Tank }\end{array}$ & 55 & 5.96 \\
\hline 20 & $\begin{array}{l}\text { Appuryanajaddi } \\
\text { Tank }\end{array}$ & 58 & 3.4 \\
\hline 21 & $\begin{array}{c}\text { Hakkimane \#1 } \\
\text { Tank }\end{array}$ & 78 & 6.81 \\
\hline 22 & $\begin{array}{c}\text { Hakkimane \#2 } \\
\text { Tank }\end{array}$ & 65 & 0.85 \\
\hline 22 & $\begin{array}{c}\text { Jaanamaki } \\
\text { Tank }\end{array}$ & 96 & 17.87 \\
\hline 23 & Choudi Tank & 59 & 3.4 \\
\hline 24 & Malenalli Tank & 38 & 8.51 \\
\hline 25 & Emme Tank & 101 & 10.21 \\
\hline 26 & Arsapura Tank & 49 & 4.26 \\
\hline 27 & Dalavaayi Tank & 195 & 34.04 \\
\hline 28 & $\begin{array}{c}\text { Keshinamane } \\
\text { Tank }\end{array}$ & 158 & 42.56 \\
\hline 30 & $\begin{array}{l}\text { Nagarakura } \\
\text { Tank }\end{array}$ & 140 & 25.53 \\
\hline 31 & Beerala Tank & 117 & 17.02 \\
\hline 32 & $\begin{array}{c}\text { Mulukina } \\
\text { Koppa Tank }\end{array}$ & 101 & 18.72 \\
\hline
\end{tabular}


33

34

35

36

37

38

39

40

$$
\begin{aligned}
& \text { Golikoppa } \\
& \text { Tank }
\end{aligned}
$$

Belale Tank

$$
\begin{gathered}
\text { Shindigere } \\
\text { Tank }
\end{gathered}
$$

Hanmanth

Devara Tank

Keresara Tank

Manthaguli

Tank

Basavana Tank

67

32

36

115

14.47

15.32

74

34.90

16.17

7.66

5.11

6.81

19

13

23

Bekkina Jaddi Tank
9.36

\begin{tabular}{lll} 
Total & 3898 & 697.9 \\
\hline
\end{tabular}

\subsubsection{Curve Number Estimation}

Table 1-10 gives individual CNs using the HSG and land use/land cover of each class in the study area. These CNs use the standard AMC-II value that has been assigned by default to specific land use categories as followed from the classifications by Im et al. (2007), Rao et al. (2010), and Rajbanshi (2016). The CNs will be assigned to AMC-I and AMC-III values through the conversion formulas after the weighted $\mathrm{CN}$ is calculated.

The total area of the land use is then multiplied by its distinct $\mathrm{CN}$ and totaled to calculate the weighted $\mathrm{CN}$. 
Table 1-10. Distribution of land use/land cover with respective HSG and Curve Number statistics

\begin{tabular}{|c|c|c|c|c|c|}
\hline Class \# & $\begin{array}{c}\text { Land } \\
\text { Use/Land } \\
\text { Cover } \\
\end{array}$ & HSG & $\begin{array}{c}\text { Curve } \\
\text { Number } \\
(\mathrm{CN})\end{array}$ & $\begin{array}{c}\text { Area } \\
(\mathrm{Sq} \mathrm{km} .)\end{array}$ & $\mathrm{CN} \times \mathrm{A}$ \\
\hline \multirow{3}{*}{1} & \multirow{2}{*}{ Areca Nut } & B & 73 & 8.84 & 645.32 \\
\hline & & $\mathrm{D}$ & 81 & 0.8 & 64.80 \\
\hline & \multirow{4}{*}{ Barren Land } & & Total & 9.64 & 710.12 \\
\hline \multirow{3}{*}{2} & & B & 79 & 2.67 & 210.93 \\
\hline & & $\mathrm{D}$ & 89 & 1.6 & 142.4 \\
\hline & & & Total & 4.27 & 353.33 \\
\hline \multirow{3}{*}{3} & \multirow{3}{*}{ Coconut } & B & 73 & 2.21 & 161.33 \\
\hline & & $\mathrm{D}$ & 81 & 0.21 & 17.01 \\
\hline & & & Total & 2.42 & 178.34 \\
\hline \multirow{3}{*}{4} & \multirow{3}{*}{ Rice Paddy } & B & 82 & 1.5 & 123 \\
\hline & & $\mathrm{D}$ & 86 & 0.3 & 25.8 \\
\hline & & & Total & 1.8 & 148.8 \\
\hline \multirow{3}{*}{5} & \multirow{3}{*}{ Trees } & B & 67 & 35.5 & 2378.5 \\
\hline & & $\mathrm{D}$ & 78 & 2.39 & 186.42 \\
\hline & & & Total & 37.89 & 2564.92 \\
\hline \multirow{3}{*}{6} & $\begin{array}{l}\text { Urban \& } \\
\text { Built-Up }\end{array}$ & B & 86 & 0.85 & 73.1 \\
\hline & & $\mathrm{D}$ & 93 & 0.4 & 37.2 \\
\hline & & & Total & 1.25 & 110.3 \\
\hline \multirow[t]{2}{*}{7} & Water & B & 100 & 2.46 & 246 \\
\hline & & $\mathrm{D}$ & 100 & 0.66 & 66 \\
\hline
\end{tabular}


As seen in Table 1-10, there are a variation of CNs depending on the potential for runoff, where the higher the $\mathrm{CN}$, the higher the potential. The SCS-CN method includes a variety of pre-constructed $\mathrm{CN}$ values of different land cover, treatment scenarios, hydrologic conditions, and hydrologic soil groups. The relevant values for our study area were identified and implemented into the table. Areca nut coverage is a dense tree farm in good condition with HSG-D and is assigned a CN score of 79. Barren land coverage is defined by its fallow, bare soil with HSG-D and is assigned a CN of 94. Coconut coverage is less dense tree farm than Areca nut and with HSG-D is assigned a CN of 79.

Rice paddy land coverage is akin to a contoured wetland surface during most of the year and with HSG-D is assigned a CN of 82. Trees represent dense forest canopy coverage of the study area and with HSG-D are assigned a CN of 77. Urban land in the area is scarce and low density, although it still introduces impervious surfaces to the area, thus obtaining a $\mathrm{CN}$ of 85 . Finally, water represents streams, irrigation tanks, and rivers in the study area and acts as a sink for runoff, thus obtaining a CN of 100 . Individual CNs are then synthesized into a single weighted variable for use in runoff estimation. The weighted $\mathrm{CN}$ equation 1-2 for the study area is evaluated as follows:

$C N=\sum_{i=1}^{n} C N_{i} \times A_{i}=C N=\sum_{i=1}^{7} C N_{i} \times A_{i}=$

$710.12+353.33+178.34+148.8+2564.92+110.3+312=4377.81$

$\sum_{i=1}^{7} A_{i}=$ 
$9.64+4.27+2.42+1.8+37.89+1.25+3.12=60.39$

$\sum_{i=1}^{7} \frac{C N_{i} \times A_{i}}{A_{i}}=\frac{4377.81}{60.39}=72.47$

Weighted $\mathrm{CN}$ for AMC-II $(C N I I)=73$

Weighted $\mathrm{CN}$ is then assigned to equation 1-3 to calculate the potential maximum

retention (S) equation: $S=\frac{25400}{C N I I}-254$

$S=\frac{25400}{73}-254=93.9$

The S variable for CNII is implemented into equations $1-4$ and 1-5 to extract $C N I$ and CNIII values:

$C N I=\frac{4.2 \times C N I I}{10-(0.058 \times C N I I)}=C N I=\frac{4.2 \times 73}{10-(0.058 \times 73)}=53.17$
$C N I I I=\frac{23 \times C N I I}{10+(0.13 \times C N I I)}=C N I I I=\frac{23 \times 73}{10+(0.13 \times 73)}=86.15$

The values converted from the AMC-II value were found to be 53 for CNI and 86 and CNIII. The results are then input into the final surface runoff equation and monthly runoff between 2009 and 2017 is calculated based on varying AMC values.

\subsubsection{Estimation of Runoff Depth}

Table 1-11. Estimation of runoff using weighted curve numbers and rainfall events between 2009 and 2017

\begin{tabular}{ccccc}
\hline Month/Year & $\begin{array}{c}\text { Rainfall } \\
(\mathbf{m m})\end{array}$ & AMC Value & \multicolumn{2}{c}{ Storm-Runoff (Q) } \\
& 39.8 & I & 3.80 & \% \\
\hline May, 2009 & 209.4 & I & 55.32 & 26.42 \\
June, 2009 & & & &
\end{tabular}




\begin{tabular}{|c|c|c|c|c|}
\hline July, 2009 & 1209.6 & II & 1094.44 & 90.48 \\
\hline August, 2009 & 216.4 & III & 170.16 & 78.63 \\
\hline September, 2009 & 320.6 & III & 272.33 & 84.94 \\
\hline October, 2009 & 185.6 & II & 98.61 & 53.13 \\
\hline November, 2009 & 74.2 & I & 0.22 & 0.29 \\
\hline May, 2010 & 53.6 & I & 0.87 & 1.62 \\
\hline June, 2010 & 376.2 & I & 179.31 & 47.66 \\
\hline July, 2010 & 717.6 & II & 606.79 & 84.56 \\
\hline August, 2010 & 451.0 & III & 401.43 & 89.01 \\
\hline September, 2010 & 317.8 & III & 269.57 & 84.82 \\
\hline October, 2010 & 60.0 & II & 8.06 & 13.43 \\
\hline November, 2010 & 121.6 & I & 10.67 & 8.78 \\
\hline May, 2011 & 31.8 & I & 6.62 & 20.81 \\
\hline June, 2011 & 778.6 & I & 541.30 & 69.52 \\
\hline July, 2011 & 623.8 & III & 573.31 & 91.91 \\
\hline August, 2011 & 598.2 & II & 489.41 & 81.81 \\
\hline September, 2011 & 444.6 & III & 395.08 & 88.86 \\
\hline October, 2011 & 141.6 & I & 18.61 & 13.14 \\
\hline November, 2011 & 67.8 & II & 11.76 & 17.35 \\
\hline May, 2012 & 14.6 & I & 16.11 & 110.32 \\
\hline June, 2012 & 228.8 & I & 67.84 & 29.65 \\
\hline July, 2012 & 513.6 & II & 406.75 & 79.20 \\
\hline August, 2012 & 649.6 & III & 599.01 & 92.21 \\
\hline September, 2012 & 274.2 & III & 226.66 & 82.66 \\
\hline
\end{tabular}




\begin{tabular}{|c|c|c|c|c|}
\hline October, 2012 & 46.2 & II & 2.90 & 6.29 \\
\hline November, 2012 & 68.8 & II & 11.76 & 17.84 \\
\hline May, 2013 & 56.0 & I & 0.58 & 1.04 \\
\hline June, 2013 & 514.4 & I & 298.17 & 57.96 \\
\hline July, 2013 & 1226.8 & II & 1111.55 & 90.61 \\
\hline August, 2013 & 396.4 & III & 347.28 & 87.61 \\
\hline September, 2013 & 230 & I & 68.63 & 29.84 \\
\hline October, 2013 & 89.4 & I & 2.02 & 2.26 \\
\hline November, 2013 & 27.6 & I & 8.48 & 30.70 \\
\hline May, 2014 & 170.6 & I & 32.73 & 19.19 \\
\hline June, 2014 & 310.6 & I & 126.90 & 40.86 \\
\hline July, 2014 & 929.8 & I & 685.05 & 73.68 \\
\hline August, 2014 & 661.2 & III & 610.57 & 92.34 \\
\hline September, 2014 & 241.2 & III & 194.33 & 80.57 \\
\hline October, 2014 & 212.8 & III & 166.66 & 78.32 \\
\hline November, 2014 & 26.4 & I & 9.06 & 34.31 \\
\hline May, 2015 & 56.4 & I & 0.54 & 0.95 \\
\hline June, 2015 & 712.4 & I & 479.18 & 67.26 \\
\hline July, 2015 & 368.4 & I & 172.91 & 46.94 \\
\hline August, 2015 & 309.2 & III & 261.09 & 84.44 \\
\hline September, 2015 & 194.4 & I & 46.16 & 23.75 \\
\hline October, 2015 & 66.6 & II & 11.16 & 16.76 \\
\hline November, 2015 & 105.8 & I & 5.70 & 5.39 \\
\hline May, 2016 & 76.4 & I & 0.37 & 0.48 \\
\hline
\end{tabular}




\begin{tabular}{ccrrr} 
June, 2016 & 345.6 & I & 154.44 & 44.69 \\
July, 2016 & 411.6 & III & 362.34 & 88.03 \\
August, 2016 & 370.8 & I & 174.88 & 47.16 \\
September, 2016 & 124.6 & I & 11.75 & 9.43 \\
October, 2016 & 43.2 & I & 2.86 & 6.62 \\
November, 2016 & 46.8 & I & 2.03 & 4.33 \\
May, 2017 & 38.0 & I & 4.35 & 11.46 \\
June, 2017 & 685.2 & I & 453.84 & 66.23 \\
July, 2017 & 1038.6 & III & 987.12 & 95.04 \\
August, 2017 & 459.8 & I & 250.18 & 54.41 \\
September, 2017 & 356 & III & 307.29 & 86.32 \\
October, 2017 & 279.4 & III & 231.77 & 82.95 \\
November, 2017 & 12.8 & II & 3.01 & 23.50 \\
\hline
\end{tabular}

Runoff $(\mathrm{Q})$ is designed with the equation 1-7.

$$
Q=\frac{(P-0.3 S)^{2}}{(P+0.7 S)}
$$

Potential maximum retention of water by the soil in $\mathrm{mm}(\mathrm{S})$ is calculated as

$$
\begin{aligned}
& S=93.9 \mathrm{~S} \text { for AMC-II } \\
& S=223.7 \mathrm{~S} \text { for AMC-I } \\
& S=40.8 \mathrm{~S} \text { for AMC-III }
\end{aligned}
$$

Table 1-11 gives monthly data on the relationship between rainfall and runoff. During the month of May, the antecedent moisture condition for the previous 5-day period is consistently less than $13 \mathrm{~mm}$ and is given the $\mathrm{S}$ value derived from AMC-I. 
These results show that, on average, may only had $17 \%$ of rainfall lost through surface runoff, while the remaining amount infiltrated the soil. However, for June, July, August, and September, the AMC would range from AMC-I to AMC-III and over $50 \%$ of the average rainfall became surface runoff. The retention storage for the months that fall in the monsoon season is low due to the constant inundation of water throughout these months, and rainfall consistently exceeded the storage capacity of the land cover types and HSGs. The high percentage of runoff is consistent with previous studies, as can be seen in Pal and Samanta's (2011) study, which had variations of monthly runoff in the monsoon season between $70 \%$ and $90 \%$ of the respective rainfall.

The weighted curve number for AMC-II is 73 , which suggests that the study area has moderate to high runoff capabilities. The correlation between runoff and rainfall can be used for appropriate water and land management by understanding the percentage loss of water during different periods of the year. Cropping patterns can be manipulated and temporally balanced determined by runoff trends and further modelling could be done to find suitable sites for implementation of terraces, diversion of stream channels, irrigation tanks, and recharge trenches (Muthu et al. 2015).

We used the monthly averages to calculate for annual trends between rainfall and runoff, as seen in Table 1-12. The average annual runoff was estimated to be approximately $67.3 \%$ of total average annual rainfall, and Figure 1-7 portrays the linear relationship between the two. Much of the rainwater in the study area is converted to surface runoff, which gives a potential for an increase in water resources for the rural farmers through better capture methods of the lost rainfall. 
Table 1-12. Yearly rainfall compared with runoff between the months of May November

\begin{tabular}{cccc}
\hline Year & Rainfall mm & mm & Runoff \\
\hline 2009 & 2347 & 1694.88 & 72.21 \\
2010 & 2189 & 1476.7 & 67.46 \\
2011 & 2798 & 2036.09 & 72.77 \\
2012 & 1869 & 1331.03 & 71.22 \\
2013 & 2587 & 1836.71 & 71 \\
2014 & 2728 & 1825.3 & 66.91 \\
2015 & 1863 & 976.74 & 52.43 \\
2016 & 1428 & 708.67 & 49.63 \\
2017 & 2868 & 2237.56 & 78.02 \\
\hline Average & $\mathbf{2 2 9 7 . 4}$ & $\mathbf{1 5 6 9 . 2 9}$ & $\mathbf{6 6 . 8 5}$ \\
\hline
\end{tabular}

Figure 1-7. Graph showing the linear correlation between annual rainfall and runoff

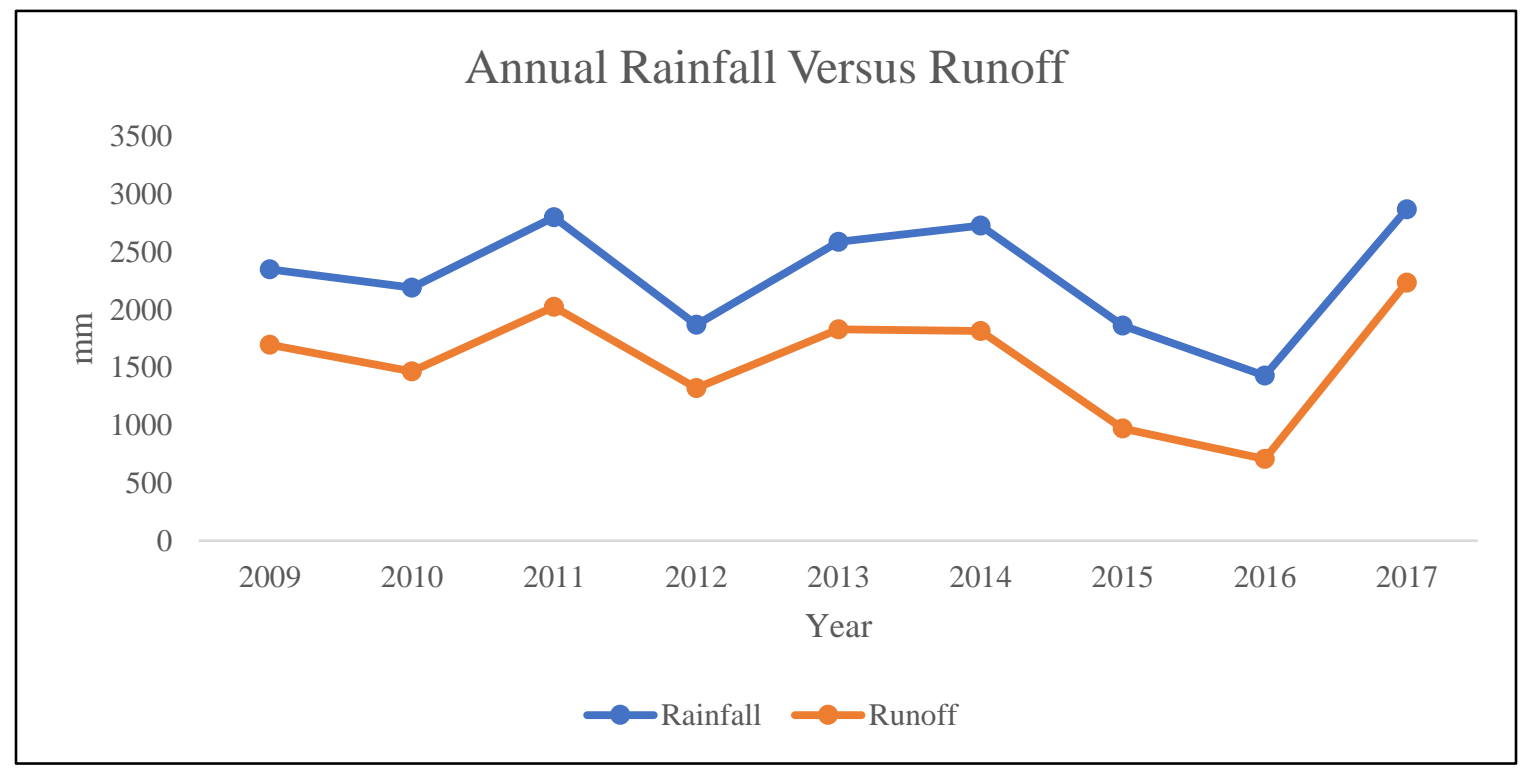




\subsection{CONCLUSION}

From our study, remote sensing and GIS technology were shown to enhance the possibilities of watershed management at a small scale and these methods can be applied to conservation efforts throughout India. The traditional processes of calculating rainfallrunoff, watershed delineation, and land cover classification have become more streamlined and efficient with the utilization of these tools. Many studies have been done using the SCS-CN method for Indian watersheds, but we have applied the calculated surface runoff values in a practical manner.

High accuracy land use maps with underlying metadata on the distribution of land cover can play a multi-faceted role in improvement of management strategies and implementation of site suitability analyses for new irrigation structures. In addition, understanding the accumulation of flow along with stream orders and how irrigation tanks play a part in the movement of water resources can also improve cropping patterns based on the size and shape of the different tank command areas. Resource managers and water users' associations can use monthly runoff estimates for individual tanks to prioritize tanks for restoration, plan wet- and dry- season crop production plans in a more effective way, and plan other activities needing water in and around tank areas.

With knowledge of runoff, we will be able to calculate for a specific amount of water resources that could be captured and used for agricultural purposes in the event of a dam being constructed in the Shalmala River in Chapter 3. The surface runoff in the area has been consistently high throughout the years that were studied averaging around 67\% of rainfall flow. 
India is the world's largest consumer of groundwater resources, and this unregulated dependence on this resource has led to increasing overexploitation in watersheds around the country (Fishman et al. 2015). In the study area also, in addition to rainwater and surface water, groundwater is a significant component of total water supply for crops and animals in the study area. Therefore, there is a critical need for better management and conservation of surface water resources during the monsoon period to promote recharge of the groundwater table. Furthermore, through the rainfall-runoff calculation method, the available flow in the study area can be synchronized with the demand for water resources, thus allowing for an efficient water management scheme derived from the SCS-CN method.

Future studies may apply the results of this research to identify suitable sites for water harvesting structures such as check dams, filtration tanks, and new irrigation tanks. Agricultural communities can also take advantage of the delineated micro-watershed areas to improve cropping pattern management. In conclusion, these tools can be applied effectively when making decisions on irrigation management in small- and large-scale projects around the country.

\subsection{REFERENCES}

Abhijit M. Zende and R. Nagarajan (2014); Analysis of surface Runoff form Yerala River Basin using SCS-CN and GIS; International Journal of Geomatics and Geosciences, Vol. 4, No.3, pp.508-516.

Anbazhagan, S., Ramasamy, S. M., \& Das Gupta, S. (2005). Remote sensing and GIS for artificial recharge study, runoff estimation and planning in Ayyar basin, Tamil Nadu, India. Environmental Geology, 48(2), 158-170. https://doi.org/10.1007/s00254-005-1284-4

Bendix, 1976. MDAS Technical Description, BSR 4210, Ann Arbor, Michigan 
Borengasser, M., Hungate, W. S., and R. Watkins, 2008, Hy- perspectral Remote Sensing: Principles and Applications, Boca Raton: CRC Press, 119 p.

Bhojaraja, B. E., Hegde, G., Pruthviraj, U., Shetty, A., \& Nagaraj, M. K. (2015). Mapping Agewise Discrimination of Arecanut Crop Water Requirement Using Hyperspectral Remote Sensing. Aquatic Procedia, 4(Icwrcoe), 1437-1444. https://doi.org/10.1016/j.aqpro.2015.02.186

Burrough PA, McDonnell RA (1988) Principles of geographical information system. Oxford University Press, Oxford, p 333

Chow VT (1964) Handbook of Applied Hydrology. McGraw Hill, New York

D. Ramakrishnan, A Bandyopadhyay, K N Kusuma (2009); SCS-CN and GIS based approach for identifying potential water harvesting sites in the Kali watershed, Mahi River Basin, India; J. Earth Syst. Sci. 118 No.4, pp.355 -363

Fetter CW (1999). Contaminant Hydrogeology. Prentice-Hall, Englewood Cliffs, NJ.

Hakeem, K. A., \& Raju, P. V. (2009). Use of high-resolution satellite data for the structural and agricultural inventory of tank irrigation systems. International Journal of Remote Sensing, 30(14), 3613-3623. https://doi.org/10.1080/01431160802590488

Hawkins, R., Ward, T., Donald, W., \& Van Mullen, J. (2009). Curve Number Hydrology. American Society of Civil Engineers. 1-106.

Hudak PF, Sanmanee S (2003). Spatial patterns of nitrate, chloride, sulfate, and fluoride concentrations in the woodbine aquifer of NorthCentral Texas. Environ. Monitor. Assess., 82: 311-320.

Immerzeel, W. W., Gaur, A., \& Zwart, S. J. (2008). Integrating remote sensing and a process-based hydrological model to evaluate water use and productivity in a south Indian catchment. Agricultural Water Management, 95(1), 11-24. https://doi.org/10.1016/j.agwat.2007.08.006

Jasrotia AS and Singh R (2006) Modeling runoff and soil erosion in a catchment area, using the GIS, in the Himalayan region, India. Environ Geol 51: 29-37

Kumar, R., Singh, R. D., \& Sharma, K. D. (2005). Water resources of India. Current Science, 89(5), 794-811. https://doi.org/10.1002/047147844X.wr243

Kumar, M., Kumar, N., Singh, K. P., Kumar, P., Srinivas, K., \& Srivastva, A. K. (2009). Integrating water harvesting and gravity-fed micro-irrigation system for efficient water management in terraced land for growing vegetables. Biosystems 
Engineering, 102(1), 106-113.

https://doi.org/10.1016/j.biosystemseng.2008.09.026

Makin, I. W., Bastiaanssen, W. G., \& Molden, D. J. (2000). Remote sensing for irrigated agriculture: examples from research and possible applications. Agricultural Water Management, 46(2), 137-155.

Mall, R. K., Gupta, A., Singh, R. S., \& ... (2006). Water resources and climate change: an Indian perspective. Current ..., 90(12), 1610-1626.

McCuen RH (1982) A Guide to hydrologic analysis using SCS methods. Prentice-Hall Inc., Englewood

Narayana DVV (2002) Soil and Water Conservation Research in India. Indian Council of Agricultural Research, New Delhi

Narendra K and Rao KN (2006) Morphometry of the Mehadrigedda watershed, Visakhapatnam district, Andhra Pradesh using GIS and Resourcesat data. J Indian Soc Remote Sens 34(2): 101-110

Nas B, Berktay A (2006). Groundwater contamination by nitrates in the City of Konya, (Turkey): A GIS perspective. J. Environ. Manage., 79(1): 30-37.

Olajire AA, Imeokparia FE (2001). Water quality assessment of Osun River: Studies on inorganic nutrients. Environ. Monitor. Assess., 69(1): 17-28

Olofsson, P., Foody, G. M., Herold, M., Stehman, S. V., Woodcock, C. E., \& Wulder, M. A. (2014). Good practices for estimating area and assessing accuracy of land change. Remote Sensing of Environment, 148, 42-57. https://doi.org/10.1016/j.rse.2014.02.015

Pal, B. (2016). Surface runoff estimation and mapping using Remote Sensing and Geographic Information System Surface runoff Estimation and Mapping Using Remote Sensing and Geographic Information System. (February).

Raj, P. K., \& Chandrakantha, P. M. G. (2015). Government of Karnataka State of Environment Report for Karnataka 2015 Water Resources and Irrigation Management. 1-36.

Rao KN and Narendra K (2006) Mapping and evaluation of urban sprawling is the Mehadrigedda watershed in Visakhapatnam metropolitan region using remote sensing and GIS. Current Science 91(11):1552-1557.

Rao, K. N., Narendra, K., \& Latha, P. S. (2010). An integrated study of geospatial information technologies for surface runoff estimation in an agricultural 
watershed, India. Journal of the Indian Society of Remote Sensing, 38(2), 255267. https://doi.org/10.1007/s12524-010-0032-8

Rolland, A., \& Rangarajan, R. (2013). Runoff estimation and potential recharge site delineation using analytic hierarchy process. Geocarto International, 28(2), 159170. https://doi.org/10.1080/10106049.2012.665499

Rupa Kumar, K., Krishna Kumar, K., Prasanna, V., Kamala, K., Deshpande, N.R., Patwardhan, S.K., Pant, G.B. (2003). "Future climate scenarios. In Climate Change and India: Vulnerability Assessment and Adaptation" (eds Shukla, P. R., Subodh K. Sharma, Ravindranath, N. H., Amit Garg and Sumana Bhattacharya), Universities Press, Hyderabad, 2003, 69-127.

S, H. S. (2017). Soil Mapping and Classification using Remote Sensing and GIS in Sullia Taluk, DK, Karnataka, India. 18147-18152. https://doi.org/10.15680/IJIRSET.2017.0609077

Samant, H., \& Subramanyan, V. (1998). Land use/Land Cover Change and Its Effects on Drainage Basins and Channels - A Study Using GIS, 26(1).

Shwetank, Kamal, J., \& Bhatia, K. J. (2010). Review of Rice Crop Identification and Classification using Hyper- Spectral Image Processing System. International Journal of Computer Science \& Communication, 1(1), 253-258.

Singh, R., Jhorar, R. K., van Dam, J. C., \& Feddes, R. A. (2006). Distributed Eco hydrological modelling to evaluate irrigation system performance in Sirsi district, India II: Impact of viable water management scenarios. Journal of Hydrology, 329(3-4), 714-723. https://doi.org/10.1016/j.jhydrol.2006.03.016

Smiet A.C., (1996), Landscape and Forest ecology of the Konto river upper watershed, Java, ITC journal, 1996-3/4, pg.: 215-224

Thiruvengadachari, S. (1981). Satellite sensing of irrigation patterns in semiarid areas: an Indian study. Photogrammetric Engineering and Remote Sensing (USA), 47(10), 1493-1499. 


\section{CHAPTER 2}

\section{MULTI-CRITERIA DECISION ANALYSIS FOR SUSTAINABLE PLANNING AND MANAGEMENT OF IRRIGATION TANKS IN KARNATAKA, INDIA}

\subsection{INTRODUCTION}

Tank irrigation is one of the most common existing irrigation resources in India. The system of small irrigation tanks plays an essential role in sustaining food production (Singh, 1994). These tanks have allowed for farmers to meet agricultural waters needs as well as their domestic needs. India is one of the largest countries in the world in terms of population and food production, making irrigation services and proper distribution of water resources crucial. The irrigation sector in general is also susceptible to erratic rainfall and climate change (Palanisami et al. 2010).

Irrigation tanks vary in size and comprise roughly $30 \%$ of the irrigated area in Southern India. Irrigation tanks are categorized as medium irrigation structures and consist of a small pond built on the slope of a valley to allow for optimal capture and storage of runoff. They often act as a chain to capture surface runoff through the system and eventually lead to rivers and streams (Mosse 1997). From an economical perspective, the tanks are an ideal system to implement innovative sustainable measures (Arumugam et al. 1997). These water-holding tanks were constructed hundreds of years ago and are linked to rural South Indian villages through deep-seated societal, economic, and cultural norms.

In general, India receives enough levels of rainfall over the course of a year to provide water to the irrigation tanks. However, the precipitation occurs almost 
exclusively during the monsoon season (June-December) and only in certain geographical regions. Even in the wet season (October-December), irrigation still encompasses $80 \%$ of water needs to rice paddy, with the remaining $20 \%$ coming from rainfall (Palanisami et al. 2008). As such, the primary limitation on sufficient agricultural yields is the uneven and inconsistent distribution of water resources (Anbumozhi et al. 2001).

Researchers have predicted longer drought periods in India in the future, resulting in a greater requirement for proper irrigation management (IPCC 2007; Palanisami et al. 2010). The water shortage is probable even if total precipitation remained constant during the growing season in rural agroecosystems across the country In addition, increased anthropogenic exploits through developmental activities are adding stress to India's watersheds (Eheart \& Tornil, 1999). These include diversion or modification of river channels, increased runoff from agriculture, deforestation, and urbanization, and large-scale hydrological projects that add to the existing threshold of greenhouse gases in the atmosphere (Ramesh \& Yadava, 2005)

Irrigation tanks also bring other direct socioecological benefits: (a) acting as flood plains and sinks for excess rainfall and debris, (b) serving as a buffer for water during heavy drought periods, and (c) offering relief from stressed groundwater resources (Sakthivadivel et al. 2004). Furthermore, indirect benefits of tanks include increased opportunity for low income individuals through the facilitation of drinking water as well as fish harvesting (Lipton 2003). Even from an ecological standpoint, these tanks allow for water storage that percolates through the water table, which augments the native habitat for flora and fauna (Palanisami et al. 2008). Therefore, the performance of tanks 
directly influences people's livelihoods through the potential for agricultural yields, fisheries, livestock, and domestic water necessities (Sakthivadivel et al. 2004).

Canal and open well irrigations systems have a larger extent of irrigation potential, however smaller community irrigation tanks provide the advantage of having an inexpensive and rapid construction process, as well as the convenience of local water transport. The specific command areas also have more focused management of the tank water and can make better decisions depending on the location of the irrigation flow rather than having to deal with large-scale river reservoirs with the inconsistent and extensive distribution of irrigation water (Chandrasekarana et al. 2009).

Furthermore, construction costs for newer irrigation systems dwarf that of restoration and maintenance of current infrastructure. Larger irrigation projects run into other limitations as well, as benefits are provided to only a specific area and because physical attributes of the land impede development (Palanisami \& Easter 1984). Tank irrigation has the capacity to provide for more agricultural land with the participation of the local community in the development and renovation processes.

However, over the years, these tanks systems have become much less efficient and reliable as a result of a host of factors. Tanks have become increasingly vulnerable to broader climatic and ecological changes at the regional level (Palanisami et al. 2010). Political and socio-economic factors have begun to play an even greater role at the village level than in the past. Irrigation tanks often serve as a common pool resource and suffer from the tragedy of the commons, and as such, collective action is essential for sustainability. 
In addition, roughly $75 \%$ of tank irrigation farmers either have the bare minimum level of income or are small-scale, meaning that personal investment into private wells is not economically feasible for these people (Palanisami, 2006). Securing the availability of water past the monsoon season in tanks is a viable management strategy especially for small farmers. The national and state agencies have started to take notice of the need for management of the preexisting irrigation infrastructure. In the past, programs have been enforced to rehabilitate tank irrigation throughout South India. However, the enforcements and regulations were mostly inadequate and only allowed for insignificant improvements and expected efficiency results of the tanks were not attained (Anbumozhi et al. 1995; Shah \& Raju, 2001; Navaneeth, 2007).

The European Economic Committee (EEC) introduced a modernization program for hundreds of tanks in southwest Tamil Nadu during the 1980s and 90s. Proper management of water irrigation tanks showed potential to induce improved agricultural yields and increased rural incomes after modernization. The EEC improvements paved the way for the revival of tank irrigation and have encouraged many other rural farming communities to follow suit with policy changes and budget provisions (Jegadeesan \& Koichi, 2011).

India's modest effort to modernize irrigation tanks, called the "Modernization of Tanks program", is a step towards improved management (Anbuomozhi et al. 2001). There are a vast number of tanks in need of restoration across the county. Administrators at the district level often grapple with the question of how to choose tanks for modernization with a limited budget. The current process solicits inputs from the village level governing body (Panchayat), local state legislative representatives, and community 
members (personal communication with Vikas Naik). Although the allocative decision seems transparent, not all underlying hydrological and socio-economic factors receive full consideration.

The present paper argues that the rejuvenation of traditional irrigation systems must be designed following a scientific and more comprehensive approach to ensure that the traditional tank irritation systems contribute to local agricultural, socio-economic, and ecological improvements. Balasubramanian and Govindasamy (1991) suggest that a performance-based ranking approach guide the decision to choose tanks for modernization. They find that factors such as cost of maintenance, water storage, and existence of water users' associations influence performance of tanks. We developed a comprehensive method to rank irrigation tanks for restoration using hydrological, economic, and social attributes.

We focus our research on a mosaic of irrigation tanks in the Bhairumbe and Taragod Panchayats of Uttara Kannada district in Karnataka, a rural farming community that has experienced deteriorating agricultural irrigation tanks. The irrigation tanks found in the study area are not being utilized to their fullest potential. The past five to ten years have seen a reduction in yields of staple crops such as rice, coconut, areca nut, and banana primarily due to the fluctuating surface and groundwater reserves as well as erratic seasonal precipitation measured in surrounding Taluks (administrative divisions in India). When compared to other studies with similar problems, the study area could be an indicator that existing water resources available for irrigation are losing efficiency because of a lack of resources, budget, as well as participatory and institutional management (Davithuraj et al. 2016). 
The study area has been chosen to understand if the existing network of age-old irrigation tanks can be restored and improved using a multi-criteria approach that allows for both quantitative and qualitative attributes of tanks to be considered. With the exception of Balasubramanian and Govindasamy (1991), who studied a limited number of indicators, no systematic and comprehensive studies have developed a decision tool to prioritize tanks for modernization in the area.

A scientific approach might shed light on the potential and proper utilization of local water resources. Although irrigation tanks are found throughout India these systems vary greatly in size, function, and other environmental attributes. The sustainable approach for restoration must be region specific and, on a case-by-case basis. However, the general methodology to be developed in our study is adaptable to other conditions.

The multi-criteria approach we take in this study is science-based as well as participatory in nature and should assist stakeholders and decision makers with planning strategies for water resource restoration and development. The multi-criteria tool is essential to understand the natural limits and processes underlying the resource system. The focus of the present study will be on the surface water body tanks. While groundwater reserves are a vital source of water for irrigation and domestic use in the study area, the scope of this research will objectively cover surface water resources.

The specific objectives focused on the sustainable assessment and management of tanks are as follows-

1. Delineate the present status of surface water resources in the study area, with a primary focus on minor irrigation tanks and reservoirs.

2. Identify the extent and importance of tank irrigation systems across the study area. 
3. Distinguish factors that affect the performance of a tank.

4. Develop a multi-criteria assessment framework for prioritizing minor irrigation tanks for restoration.

5. Provide recommendations for classification of sustainable tank restoration to the local community and government institutions with respect to socio-economic constraints.

6. Evaluate alternative tank rehabilitation management strategies and their resulting effects in South India.

\subsection{LITERATURE REVIEW}

As irrigation tanks stand as one of the more traditional methods of irrigation, other irrigation practices have increased in popularity over the years with technological advancements. While the different practices all have their own advantages and disadvantages, it is important to note some of the key benefits that tanks have as preexisting irrigation structures. Taking the perspective of a multi-use system rather than exclusively for irrigation purposes, it is apparent that tanks take on a bigger role in India than just for agriculture. The key themes in the literature focus on how these tanks have been losing their overall value and what institutions and communities can do to better manage these resources.

\subsubsection{India's Changing Irrigation}

Rao (1968) demonstrated that the agricultural productivity in India had considerably improved because of tank and well irrigation during the 1950s. Rao's paper also observed the steep drop off of tank irrigated areas in many regions post 1960 and 
argued that the drop off was caused by the population surpassing a specific optimal threshold where the management of the tanks was no longer sustainable. The small irrigation tanks in the study experienced stagnation of irrigation potential. Since the 1960s, the stagnation has only been exacerbated, and many farming communities have begun to view the tanks as an unpredictable source of irrigation water and thus a possible risk to agricultural production.

Although the tank irrigation method for capture and storage of runoff water is deeply rooted in the India's culture, the tank-irrigated area has declined with the population density (Shah \& Raju, 2001). The Ministry of Agriculture and Farmers' Welfare reports a decrease in the total area irrigated by tanks in India between the 1960s and post 1970s from 4.5 million hectares to 4 million hectares with a decreasing trend onward. Meanwhile, the rural population density average increased exponentially during the above time period (Oppen \& Rao, 2000).

The introduction of affordable diesel and electric powered pump systems was also a factor that played into the decline of tank irrigation efficiency. Privately controlled irrigation tanks are attractive to farmers which induced a paradigm shift with resources moving towards construction of well irrigation, largely leaving tank irrigation behind (Mosse 1998). All these variables played a role in reducing the importance of tank irrigation and lowering its priority in governmental budgets. Contemporary literature shares a common perception of the current water resource issues in India and recommends traditional forms of irrigation. These studies stress the need for elevating the 
role of irrigation tanks of India, since alternative forms of irrigation are not enough to maintain agricultural productivity (Agoramoorthy 2008; Pandey 2007, Jana et al. 2012;

Arumugam et al. 1997; Palanisami \& Meinzen-Dick, 2001; Sengupta 2016).

\subsubsection{Irrigation Tanks in Karnataka}

According to the Karnataka Minor Irrigation Department, more than $70 \%$ of the current approximate number of 3,600 tanks in the state have been undergoing complete dry downs, an unprecedented level until recent years of poor monsoon periods. In addition, only about $30 \%$ of all tanks have current storage capacity of around half of their potential capacity even during the monsoon, with only $1 \%$ of the tanks having storage of greater than 50\% (Keller et al. 2000).

\subsubsection{Multiple Use Services}

While larger-scale farmland may be able to maintain yields during particularly bad monsoon seasons using groundwater well irrigation, poor households depend on the tank resources. These tanks provide irrigation along with livestock activity, fisheries, and fodder (Balasubramanian \& Selveraj, 2003). The tanks provide alternative economic benefits, but importantly play a major role in providing multiple-use water services. These include ecological functions like habitat, recharge of the groundwater table, flood control, and absorption of silt (Bassi et al. 2014).

To expand on the water resource services, tanks capture and conserve a portion of the limited rainfall in the region, as well as slowing the momentum of water that would otherwise be lost as runoff. The groundwater recharge function of tanks acts as a more reliable supply of water for both irrigation and domestic water purposes. Also, the tanks 
reduce the concentration of flooding during years with high rainfall, thus decreasing damages to the surrounding community, agriculture, and infrastructure. Finally, the tanks will accumulate silt and other minerals from surface runoff and fertilize their respective command area with these nutrients during flow irrigation (Shah \& Raju, 2001).

Furthermore, the social function of tanks is to allow for water supply for both household and agricultural use. These tanks are state-owned but are under the control of the public as common pool resources which allows anyone to utilize them for alternative applications (Sakthivadivel et al. 2004). As a consequence of the degraded status of tanks, many of the beneficiaries and stakeholders see them as worthless barren ponds and do not believe in investing for maintenance and restoration of these outdated sources (Verma 2001). However, the ecosystem-based studies conducted elsewhere in watersheds of India are emphasizing the positive ecosystem services that the tanks provide and are taking the stance of support for sustainable restoration.

Field researchers assessed the need for proper management of tanks by evaluating multiple-use services, allowing for a more comprehensive perspective. For example, performance evaluation in a study of 41 irrigation tanks across eight states chose attributes of the tanks that surpassed their original irrigation purposes. These attributes consisted of indicators such as livelihood contribution in the form of fisheries, livestock, and domestic use, as well as the performance of sustainable institutional management (Sakthivadivel et al. 2004).

Another study focused more heavily on the ecosystem services of tanks as a form of wetlands, wherein an ecological perspective was considered to look further into the 
soil, water, and biodiversity conservation attributes affected by the tanks (Verma, 2001). These tanks act as a refuge for migratory birds and other wildlife during the dry season, and thus ecological attributes must be accounted for when implementing a multi-purpose study of these tanks (Bassi et al. 2014). Once the tanks are evaluated from different angles, it is easier to understand the ideal nature for these traditional tank systems as an alternative water source.

\subsubsection{Common Pool Resources}

Irrigation tanks are among the oldest common pool water resources that can be found in Southern India. Common pool resources were defined by Bromley (1989) as "private property for a group," where non-exclusive resources are distributed among a multitude of various owners. The tanks fit this description and primarily serve the needs of the poor and marginal farmers but have been failing these beneficiaries as a result of large scale economic and institutional paradigm shifts in traditional rural communities (Nadkarni, 2000).

Singh (1994) characterized these tanks as victims of the tragedy of the commons, where uncooperative behavior towards restoration and maintenance has led to siltation from runoff and inundation of invasive plants and weeds. The distribution channels for sheet flow have also been deteriorated to the point where many of these channels have ceased to exist.

Singh (1994) finds three reasons for the lack of cooperation: (a) the private costs of co-users would be greater than that of the private benefits, (b) individual contributions would be too insignificant to affect the overall performance of the tank, and (c) finally a 
sense of distrust between co-users having fair contributions in the absence of organized leadership. A gap in literature exists between collective action and common property resource management. Much of the relevant studies focus on better strategies for sharing existing tank water in the command area rather than how to introduce more water to the tanks in a collective manner (Palanisami \& Meinzen-dick, 2001; Palanisami \& Easter, 1984; Balasubramanian \& Govindasamy, 1991).

Lise (2000) addresses the issue of collective action in common property watersheds through people's dependence on the water resources in the area. They found that higher participation was directly correlated with higher dependence on the resource. Furthermore, Ostrom (2000) provides multiple threats to collective action, including changes to technology, out-migration, lack of international aid, corruption, and opportunistic behaviors. Ostroms findings can be related to tank irrigation and management with technological innovations allowing for modernized well-drilling and groundwater extraction in a private setting. Increased development in private wells has made some farmers no longer as dependent upon the irrigation tanks. The utility of communal irrigation tanks has been deemphasized by the private well infrastructure, as water requirements for post green revolution crops could be reliably achieved along with increased fertilizer use (Balasubramanian, 2006).

Another limitation on collective action is the issue of poverty and irrigation tank at a smaller scale. For example, Balasubramanian (2006) classified dependence on tank irrigation in two administrative blocks in the district of Ramanathapuram in Tamil Nadu. They separated poor and non-poor households depending on the per capita income relative to the Government of India's poverty line for rural areas. The results of the 
Balasubramanian (2006) study showed much higher dependence on communal tank irrigation for both agricultural and domestic uses, with over $90 \%$ of poor households using tanks as their primary water source compared to only $70 \%$ of non-poor households. Alternative resources provided by the tanks such as washing, bathing, livestock, fisheries, and silt brick making also back up the results of increased dependency by poor households.

Heltberg (2001) notes that excessive integration and dependence on private wells puts the potential of sustainable irrigation tank management at risk. Therefore, cooperative effort would be necessary to enhance the improvement of community tanks. Emphasis should be placed on alternative sources of income that can be gained from community tanks to decrease reliance on tank irrigation and allow for rural agricultural communities to move the economy forward regardless of uncertain rainfall patterns.

\subsubsection{Siltation}

Siltation is a leading factor of tank degradation that reduces the water storage capacity to as little as $30 \%$. Silt and other debris become confined in tanks through sedimentation in runoff which reduces the active storage capacity and adds to the difficulty of sustainable development of the tank (Shankari 1991). Arumugam et al. (1997) explain that, on average, in the state of Tamilnadu, the state located southwest of Karnataka and with the highest number of irrigation tanks, the storage capacity of irrigation tanks can be reduced by as much as $0.5 \%$ each year.

De-siltation is a solution to this problem, which is usually performed in the dry season and involves manual and mechanical removal of silt from the tank. Studies have 
shown that the high cost of the de-siltation process makes it unviable in many scenarios. Within the Bhairumbe/Taragod study area, hiring rates of tractors can be more than 300 Rupees (Rs. 300) and the pool of skilled workers is dwindling. Researchers agree that partial de-siltation is the best course of action for restoration with budget constraints (Reddy et al. 2018).

\subsubsection{Improper Supply and Distribution}

As previously stated, the irrigation tanks are owned by the state government, meaning the government is responsible for keeping the tanks in working condition. Historically speaking, this is untrue, as can be found in both Uttara Kannada District in Karnataka and Chittoor District of Andhra Pradesh. Farmers have taken on the role of cleaning the tanks and evidence of ongoing maintenance can still be found in many villages today. Furthermore, as a result of the monsoon droughts over the past 30 years, farmers have looked to other means of irrigation, such as digging bore wells (Shankari 1991). These wells are dug out for the main purpose of pulling groundwater from deep aquifers. Bore wells disregard the degradation of tank storage capacity and has direct effects on the recharge rate of the groundwater table (Reddy et al. 2018).

Furthermore, when considering sustainability, the construction of tanks for distribution was not conceptualized with science in mind. Although the tanks were arranged so that excess seepage would continue into lower lying tanks, an estimated $45 \%$ of potential irrigation water is wasted due to the non-uniform spread of water throughout the command area (Jana et al. 2012). Modern crop water requirements were not taken 
into consideration during construction, as Karnataka has gone through a transition period of shifting cultivation to modern complementary crops.

Farmers began converting traditional rice paddy fields with the intention to produce cash crops such as Areca nut, black pepper, cardamom, and coconut. These crops accelerated the economic growth of the panchayat farmers but required advanced management strategies to be imposed on the irrigated command area. These contemporary multi-crop systems have altered the hydrological capacity and distribution potential for ground and surface waters (Basavaraja et al. 2012).

\subsubsection{Socioeconomic Factors}

Socioeconomic status has been shown to play a significant role with the distribution of water resources. Mayya (1987) used a study of irrigation tanks in Karnataka to conclude that farmers with small amounts of land and low profits were shown to neglect the water delivery tanks, and thus restricted their capacity for higher agricultural yields. This neglect was largely influenced by the lack of knowledge and awareness of scientifically backed agricultural techniques. When compared to river irrigated command areas, marginal farmers were shown to live predominantly in communities and villages that were mainly supported by the tank irrigation. Studies like this have given possible evidence that tank irrigated command areas result in the poorest farmers (Shanmugam \& Sakthivadivel, 1988). 


\subsubsection{Restoration and Participatory Management}

In the early 2000s, the World Bank funded the restoration of 2000 irrigation tanks through community-based management. Social institutions have been created to incentivize the farmers to maintain the tanks. These institutions include water users' associations (WUA), joint forest management partnerships (JFM), village forest committees (VFC), and agricultural cooperative societies. The state institutions have overarching control of forests and irrigation tanks while these social institutions have jurisdiction of local level resource allocation (Menon \& Bawa, 1997). Karnataka is among the earliest states to issue a government mandated order on participatory management. The areas that the JFM covers predominantly include degraded forestlands with a canopy density of less than $25 \%$, sides of roadways or canals, and the shorelines of irrigation tanks (Rao et al. 2001).

With irrigation policies shifting towards village management the 1990s saw rise to another group known as the water users' associations (WUAs). The WUAs have treated tank irrigation management as a collaborative goal giving farmers more rights over the resources from these systems. These programs give farmers the opportunity to maintain and restore the tanks, as well as rights to the resulting benefits including trees, silt, fish, and increased yields (CWR 1991). Another more recent principle of equity has begun to be implemented into the distribution of tank resources and budget for restoration. This cultural shift has led to researchers considering the distribution of benefits to all sizes of farmers, landless laborers, and other less represented groups. 
Many researchers believe the addition of participatory management for the restoration of irrigation tanks only portrays an illusion of decentralization (Mosse \& Nelson, 1995; Egadeesan \& Koichi, 2011; Reddy et al. 2018). JFM committees have been structured to be reactive with the state department limiting the VFC's resources to manage the local irrigation. This sets the VFC's up for failure when considering the extent of degradation in many farming communities in which no expert consultation on resource allocation is given. Oftentimes, the government water management agencies were quick to pass the responsibility of maintenance of irrigation tanks over to the village institutions without proper financial support (Kolavalli \& Brewer, 1999).

\subsubsection{Crop and Water Management}

Arumugam et al. (1997) argues that to increase the efficiency of the pre-

constructed tank irrigation systems cropping patterns must be diversified. India is one of the leading producers of rice paddy crops, the traditional crop of choice for rural farmers until a recent shift has begun towards commercial crops that make better use of the available irrigation water. Due to the unpredictability of tank water availability, farmers usually end up with late rice paddy planting and less overall crop yield.

Utilizing Tamil Nadu as a study site, Palanisami (1993) found that $39 \%$ to $76 \%$ of rural farmers who relied on rice paddy as their main crop resulted in crop failure and net income loss in five of the ten years of the study. This study also showed that the optimal cropping patterns for these small farmers is $25 \%$ rice and $75 \%$ non-rice crops, which has shown farmers the necessity of proper cropping management dependent on water resource availability. Rural farmers should be encouraged by state and community 
institutions to move away from rice production and transition to cultivation is suited for the modified conditions of irrigation availability (Shah \& Raju 2001).

\subsubsection{Equity in Water Resources}

According to state-wise poverty estimates of 2011-2012, the state of Karnataka, India still has approximately $20.9 \%$ of its population living under the poverty line (201112 Planning Commission). This number is about $10 \%$ higher in rural areas such as the

district of Uttara Kannada where the study has taken place. When approaching watershed studies from a management perspective, this large group must be acknowledged and provided for, especially when most tank users fall below the poverty line. In this sense, subsistence agriculture must take precedence when reviewing how the command areas of irrigation tanks can be restored and maintained. For this study, command areas of irrigation tanks that cover the most rice paddy acreage will serve as an individual weighted variable when prioritizing tanks for restoration.

\subsubsection{Multi Criteria Analysis for Water Resource Assessment}

The literature presents many economic valuation tools for utilization recommendations of management updates to making decisions based on factors relating to sustainability. A popular tool that allows for the input of multiple sustainability factors from observations, measurements, and focus group/key informant discussions is the Multiple Criteria Analysis (MCA) method. The MCA acts as a decision-making technique that provides relief to complex economic valuation methods that can present issues for a large set of interconnected indicators. Emphasis has been put on MCA 
decision making for an objective in which certain criteria are not easily quantified through monetary value (Munasinghe, 1992).

Various studies have been completed using these techniques for a variety of different environmental and economic decisions. Balasubramanian \& Govindasamy (1991) specifically used this tool to cover the impacts of irrigation tanks on sustainability through environmental, social, and economic performances in India. Palanisami \& Flinn (1988), Sakthivadivel et al. (2004), and Verma (2001) also utilize methodology very similar to the MCA. These researchers relied on both primary information from field visits of the tanks, as well as secondary data that was obtained from official records including rainfall data, land cover data and local agriculture data.

Zekri and Romero (1993) have utilized the MCA tool to create a comprehensive approach in compromising between public and private concerns of water use, employment, and energy needs in agriculture. Krajnc \& Glavic (2005) have taken the MCA process further and implemented multiple indicators or attributes to formulate a composite sustainable development index (ICSD) to normalize different values to better compare them to each other. These studies all relate environmental and economic criteria with a conceptual framework that considers people's perceptions during the decisionmaking process (Tiwari et al. 1999)

Numerical scores are given to express the value of an option compared to a set of other options. These scores are then rated depending on a scale of performance with a weighing mechanism implemented to give higher favor to certain attributes over others (Kiker et al. 2005). Drawbacks to this valuation method are that the MCA process 
depends on a set of assumptions about the decision makers. These assumptions include:

1) the decision makers are rational, 2) criteria preferences stay constant, and 3) the decision makers have perfect knowledge in maximization of utility for the environmental scenario (Mavrommati et al. 2017).

This tool was selected for our research as it aggregates a pool of various ecological, economic, and social indicators. This allows us to create and present a comprehensive development index to act as an alternative to current tank irrigation management practices for local state and community institutions.

\subsubsection{Cost of Restoration}

With the continued deterioration of irrigation tanks and improved technology, the cost of installation has decreased and the demand for private water resources has risen, giving more incentive for rural farmers to move in this direction (Kajisa et al. 2007). These technological advancements are not as readily utilized on the common pool irrigation tank resources as it incurs a cost to a specific individual or group that would have to share the benefits of the resource with the community. With this knowledge, restoration cost of irrigation tanks is a large factor that affects potential performance and acts as a driver for proposing a framework for prioritization of tanks within the limitations of a budget.

\subsection{METHODOLOGY}

\subsubsection{Introduction}

This chapter focuses on 40 tanks in the region that have been studied through visual observation, key informant discussions, and the collection of rainfall and land cover data. This data will help us characterize each tank for restoration purposes based on 
multiple-use attributes. These attributes will then be subject to a Multi-Criteria Decision Analysis to determine a composite sustainability index (Krajnc \& Glavic 2004).

\subsubsection{Study Area}

The study area utilized for Chapter 2 is the same as in Chapter 1 and can be referred to in Table 1-1.

\subsubsection{Stakeholders and Audience}

The most active organizations observed in the study area were rural agricultural cooperative societies. Starting out as a small gathering of farmers with a collective goal of increasing their quality of living, these cooperative societies grew to become selforganized and influential in their respective panchayats. The cooperative societies work together with local environmental scientists and geologists to better understand the effects of climate change and the exploitation of water resources in the watershed. Especially with recent water shortage within the past 5-10 years, farmers have been depending on the assistance and expertise of communal societies to teach them how to properly manage and conserve the currently available resources.

The Western Ghats has seen roughly 700 VFC's open to members interested in the development and management of their local ecosystems along with a few that fall into the proximity of the study site. VFC's were created from JFM's to plan resource allocation and restoration at the village level and give self-governance to the local communities (Rao et al. 2001). VFC's are the most influential stakeholders in the Bhairumbe/Taragod panchayats, as they make the direct decisions and investments into de-siltation and 
conservation of tanks while funded through the State Department. Both farmers and VFC's have been applying for funds for de-siltation and maintenance of the governmentowned tanks, but there is currently no standardized method to apply for budget allocation. The MCA of tanks in this study area aims to provide a different approach to restoration that will give a sustainable and economic-based multiple-service analysis of these water resources. Management recommendations will then be provided to the community and government institutions based on these findings.

\subsubsection{Delineation of Tank Resources in Study Area}

In this research, we study 40 tanks that are spread across nine out of ten villages that make up the panchayats. Most of the tanks were supplied by rain or through rain fed runoff, with some exceptions that were fed by the Shalmala River. All the chosen tanks were owned by the minor irrigation department agency which has the main jurisdiction. At the time of the study, all 40 tanks were utilized mainly for irrigation, wildlife habitat, and groundwater recharge, with five used for irrigation and fisheries, and three used for irrigation and cattle drinking. The age of the tanks is unknown, and some were said to range from 50 years old to more than 100 years.

\subsubsection{Significance of Tank Resources in the Study Area}

This research has stemmed from Shah (2003) who questioned whether it is still viable to continue a relationship between tanks and farmers in the present-day context with changed variables like population density, attitude, well irrigation, and water

recharge facilities. Many tank-irrigated communities around India are still managing their 
water resources efficiently. Although declines are obvious, it shows that these communities still have a place in society. This research was conducted in conjunction with the Hulgol Agricultural Cooperative Society to identify characteristics of tank performance and discuss how to adapt sustainable best management strategies with the current economic, social, and environmental changes in the panchayat.

\subsubsection{Relevant Attributes and Sustainability}

For evaluating the overall performance of tanks, we chose a set of indicators that best represents a cumulative contribution of these systems to the social, economic, and environmental spheres (Elbarkouky 2012). The indicators help us characterize each tank for restoration purposes based on multiple attributes including hydrological, physical, social-economic condition and water supply potential.

We have included the following nine attributes for characterizing the tanks in the study area. The environmental and socioeconomic sustainability criteria are as follows:

(1) Tank condition: the effectiveness of tank for purposes of runoff capture, soil erosion prevention, and indirect irrigation measured by observing the amount of silt, debris, and shoreline erosion, (2) Water holding capacity: measured by the current volume displayed by the tank, (3) Vegetation health: measured by the observed general health and diversity of vegetation on the shoreline and immediate surroundings, (4) Wildlife habitat health: measured by the observed population size and species diversity of fauna within the tank, on the shoreline, and immediate surroundings, (5) Acreage irrigated: measured by the area (acres) of land that is irrigated through surface runoff, (6) Access and convenience: measured by the degree of convenience for farmers and heavy machinery to easily reach 
tank for utilization and restoration purposes, (7) Usability: measured by the current and potential use for farmers or other individuals to utilize tanks as an alternative source of food/income outside of the realm of irrigation, and (8) Potential Storage: measured by the maximum potential water holding capacity of the tank.

The qualitative attributes were measured through firsthand observations along with consultation from local farmers and expert key informants. The quantitative attributes were gathered through multiple hydrological remote sensing and GIS datasets using IRS satellite imagery, stream data, precipitation data, and groundwater flow data. Table 2-1 lists these indicators with their method of measurement and performance scale. These indicators allow for a comprehensive view of tank ecosystem services through an ecological and economic perspective and provide another demonstration of ranks.

To develop the framework, the nine indicators were each given an individually constructed rubric that would assist with giving qualitative variables a quantitative result that allowed for transition into the MCA. The values on rubric for qualitative measurements contain a scale from one to five, where one represents the lowest performance and five represents the highest performance. This allowed for each tank to be measured and compared against all other tanks from nine different sustainability indicator perspectives.

Table 2-1. Indicators that influence tank performance

\begin{tabular}{cccc}
\hline $\begin{array}{c}\text { Sustainability } \\
\text { Criteria }\end{array}$ & Indicator & Description & Measurement \\
\hline Ecological & Tank Condition & Overall effectiveness of tank & Qualitative \\
& $(+)$ & $\begin{array}{c}\text { for purposes of runoff capture, } \\
\text { soil erosion prevention, and }\end{array}$ &
\end{tabular}


sheet flow potential, based on visual assessment.

Water Holding
The current status of the size
and depth of the tank,
expressed in volume, based off
ArcGIS delineated area and
key informant knowledge on
depth.

Vegetation Health

Overall health of vegetation on

Qualitative the shoreline and immediate surroundings, based on visual assessment.
Wildlife Habitat
Health (+)

Wildlife population size and

Qualitative species diversity within and around the tank, based on visual assessment.

Potential Storage

The potential volume of water

Quantitative of the tank if complete desiltation measures are taken, based on measurement of water holding capacity.

Socioeconomic

Access and

The degree of convenience for

Qualitative Convenience (+)
Crop Acreage
Irrigated (+)

farmers and other individuals

to easily reach the tank, for

religious, cultural, or

maintenance purposes, based

on visual assessment and key informant knowledge.

Acreage of land that is irrigated directly through surface runoff and flow accumulation, based on delineated catchment areas from ArcGIS and land cover map. 


$$
\begin{gathered}
\text { Usability (+) The potential for farmers and Qualitative } \\
\text { other individuals to utilize the } \\
\text { tank as an alternative source of } \\
\text { food/income, based on visual } \\
\text { assessment and key informant } \\
\text { knowledge. }
\end{gathered}
$$

Note: The (+) refers to the positive impact that that variable has on sustainability.

\subsubsection{Water Resource Attributes for Multi-Criteria Analysis}

The water resource attribute of water-holding capacity for each of the tanks was obtained through key informant observations and government documentation. For potential storage, each tank was measured based on both its current status of water storage along with the maximum potential storage yielded by the tank based on its individual surface area and depth. Measurements of tanks at the peak of the rainy season were utilized as the quantitative values for these specific attributes. Finally, the attribute for acreage irrigated was developed from Chapter 1 using ArcHydro tools in ArcGIS software.

\subsubsection{Normalized Indicator Valuation}

All chosen indicators have a positive contribution $\left(I^{+}\right)$on the sustainable development of the tanks. Following Seleman \& Bhat, 2016, the normalization formula for positive contribution indicators is as follows:

$$
I^{+}=\frac{I_{a}^{+}-I_{\min }^{+}}{I_{\max }^{+}-I_{\min }^{+}}
$$


Where $\left(I^{+}\right)$is the normalized indicator value, and $a$, min, and $\max$ are the actual, minimum and maximum values of a given indicator of a given tank, respectively. The advantage of undergoing normalized valuation is that indicators from various dimensions become compatible, although this step misses the distinction between the possible significance of certain indicators over others depending on the stakeholders and beneficiaries.

\subsubsection{Weighing Stakeholder Attribute Interests: Analytic Hierarchy Process}

Utilizing the Analytic Hierarchy Process (AHP) proposed by Saaty (1980), the weights of each indicator can be implemented into the final sustainable assessment solution. The AHP allows for a mathematical and psychological approach to running the MCA. Weights of indicators can be found from key informants or experts of the local communities that are knowledgeable about the study. Proctor and Dreschsler (2006) further validate the dimension of weighting by arguing that a citizens' jury could satisfy the requirements for an accurate assessment of stakeholder weights through the process of achieving a consensus. For this study, the weights of indicators were obtained from taking a consensus of expert farmers and scientists using a pair-wise comparison method. Informants were asked to compare two indicators at a time to each other in terms of the intensity of preference using the preference scale developed by Saaty (1980) in table 2-2. 
Table 2-2. Values and definitions of variables in the Saaty scale used for Analytical Hierarchy Process

\begin{tabular}{cl}
\hline Intensity of Importance & \multicolumn{1}{c}{ Definition } \\
\hline 1 & Equal importance \\
3 & Moderate importance of one over another \\
7 & Strong importance of one over the other \\
9 & Very strong importance of one over the other \\
$2,4,6,8$ & Extreme importance of one over the other \\
& Intermediate values when compromise is necessary
\end{tabular}

Saaty's intensity of preference scale gives us a range of factors between one and nine. Where giving the answer of one between two indicators means that they are both equal in preference, while a nine means that one specific indicator is nine times more significant than the other specific indicator that it is being compared with (Krajnc \& Glavic 2005). Once all independent judgments were made, the eigenvector of each indicator shows the importance relative to all other indicator values and all eigenvectors combined reach a value of one. The individual eigenvectors are then used as weights for the following process.

\subsubsection{Arithmetic Composite Index}

Once normalized values and weight values have been obtained, the next step is to compute the Arithmetic Composite Index formula. This formula provides a real number to defining the condition of an environmental and socioeconomic scenario through an assessment of various multidimensional attributes. The index function must utilize the 
three dimensions of sustainability: economic, environmental, and social, to properly assess the sustainability of a scenario (Mavrommati et al., 2017).

$$
I_{\text {Composite }}^{+}=W_{1} * I_{1}^{+}+W_{2} * I_{2}^{+}+W_{3} * I_{3}^{+}+\cdots W_{9} * I_{9}^{+}
$$

Where, $W_{1}, W_{2}$, etc. represent the eigenvector weights of each relative normalized indicator value, $I_{1}^{+}, I_{2}^{+}$, etc., respectively. The composite index will rank each tank from most in need of restoration to least. It will provide a list of tanks that should be focused on for restoration. The water resource development agencies can then utilize this list and strategically distribute their annual budget and resources amongst the tanks that have the most potential for irrigation and ecological success. A timeline of tanks can then be created to follow in subsequent years.

\subsubsection{Restoration Cost}

Due to limitations of the research, estimates were taken on the amount of silt to be excavated from each tank. Alternative scenarios for the quantity of de-siltation necessary were set at $30 \%, 50 \%$, and $70 \%$ of overall surface area for each individual tank. As per a key informant, the cost of tank restoration was estimated at Rs. 212 per $\mathrm{m}^{3}$ which includes the cost of excavation of silt and labor (personal communication with Dr. Ramachandra Bhatta).

\subsubsection{Sustainable Equity through Food Security}

As previously stated, the goal of creating a sustainability driven prioritization framework for these tanks is to include equity as a weighted factor so that poor and 
marginal farmers can increase their water resources and agricultural yields. With the utilization of ArcHydro tools, each of the 40 irrigation tanks were delineated based on elevation, flow direction, and flow accumulation. The tanks that covered the highest amount of subsistence agriculture (rice paddy) crops were given the highest ranks, as there is a contrast in this area between the crops that households can afford to cultivate. This contrast stems from household income, where farmers closer to the poverty line are only able to afford to cultivate paddy land rather than cash crops like coconut and areca nut.

\subsubsection{Multi-Objective Analysis}

Based on the variety of calculated factors including acreage irrigated, economicecological multi-criteria analysis, and sustainable equity rankings, a comprehensive assessment was constructed to identify the irrigation tanks that covered the widest variation of benefits towards the community. A prioritization framework was then created based on the multiple alternative restoration cost scenarios.

\subsection{RESULTS AND DISCUSSION}

Table 2-3 presents size and geographic coordinates of the study tanks. The tanks have a diverse range of surface areas ranging from $69.9 \mathrm{~m}^{2}$ to $14,022 \mathrm{~m}^{2}$. This large variation is a result of siltation buildup from runoff, encroachment of agricultural land,

and age of the individual irrigation structure. The larger tanks had a much higher volume capacity and were seen to be in a more ecologically healthy state. Coordinates of the tanks were gathered through ground referencing the study area with a handheld Global Positioning System (GPS) unit. The coordinate results showed that tanks were found throughout nine of the ten villages in the study area. 
Table 2-3. Observed tanks in the Bhairumbe/Taragod Panchayats

\begin{tabular}{|c|c|c|}
\hline Name of irrigation tank & Area (Square Meters) & $\begin{array}{c}\text { Coordinates (Decimal } \\
\text { Degrees) }\end{array}$ \\
\hline Gadigehole tank & 713.5 & $14.6894 \mathrm{~N}, 74.8199 \mathrm{E}$ \\
\hline Bugadimane tank & 1040.7 & $14.6813 \mathrm{~N}, 74.8191 \mathrm{E}$ \\
\hline Kibbali tank & 219.3 & $14.6859 \mathrm{~N}, 74.8080 \mathrm{E}$ \\
\hline Ashimane tank & 631.3 & $14.6862 \mathrm{~N}, 74.8001 \mathrm{E}$ \\
\hline Halige tank & 831.9 & $14.6763 \mathrm{~N}, 74.7941 \mathrm{E}$ \\
\hline Devari Keri tank & 1384.4 & $14.6908 \mathrm{~N}, 74.7981 \mathrm{E}$ \\
\hline Keshinamane tank & 1094.5 & $14.7091 \mathrm{~N}, 74.8306 \mathrm{E}$ \\
\hline Appurayanajaddi tank & 4313.8 & $14.7217 \mathrm{~N}, 74.8149 \mathrm{E}$ \\
\hline Dalavaayi tank & 2160.8 & $14.7120 \mathrm{~N}, 74.8306 \mathrm{E}$ \\
\hline Hakkimane \#1 tank & 1224.5 & $14.7230 \mathrm{~N}, 74.8190 \mathrm{E}$ \\
\hline Hakkimane \#2 tank & 2024.6 & $14.7074^{\circ} \mathrm{N}, 74.8196^{\circ} \mathrm{E}$ \\
\hline Emme tank & 4784.6 & $14.7172 \mathrm{~N}, 74.8184 \mathrm{E}$ \\
\hline Jaanamaki tank & 7118.2 & $14.7323 \mathrm{~N}, 74.8260 \mathrm{E}$ \\
\hline Choudi tank & 2906.0 & $14.7374 \mathrm{~N}, 74.8218 \mathrm{E}$ \\
\hline Malenalli tank & 1859.4 & $14.7305 \mathrm{~N}, 74.8334 \mathrm{E}$ \\
\hline Arsapura tank & 1439.1 & $14.7146 \mathrm{~N}, 74.8333 \mathrm{E}$ \\
\hline Nagarakura tank & 2714.2 & $14.7048 \mathrm{~N}, 74.8282 \mathrm{E}$ \\
\hline Beerala tank & 2828.8 & $14.7037 \mathrm{~N}, 74.8331 \mathrm{E}$ \\
\hline Mulukina Koppa tank & 1052.7 & $14.7076 \mathrm{~N}, 74.8364 \mathrm{E}$ \\
\hline Keresara tank & 462.9 & $14.7146 \mathrm{~N}, 74.8450 \mathrm{E}$ \\
\hline Taragod tank & 9509.4 & $14.6769 \mathrm{~N}, 74.8377 \mathrm{E}$ \\
\hline Ambalike tank & 5374.0 & $14.6589 \mathrm{~N}, 74.8321 \mathrm{E}$ \\
\hline Kathlehalla tank & 14022.0 & $14.6703 \mathrm{~N}, 74.8536 \mathrm{E}$ \\
\hline
\end{tabular}




\begin{tabular}{|c|c|c|}
\hline Nidagod tank & 2396.5 & $14.6824 \mathrm{~N}, 74.8445 \mathrm{E}$ \\
\hline Anchigadde tank & 1313.4 & $14.6830 \mathrm{~N}, 74.8387 \mathrm{E}$ \\
\hline Chowdi tank & 1183.0 & $14.6851 \mathrm{~N}, 74.8338 \mathrm{E}$ \\
\hline Moolimane Nidagod tank & 1544.5 & $14.6874 \mathrm{~N}, 74.8383 \mathrm{E}$ \\
\hline Manthaguli tank & 751.0 & $14.7198 \mathrm{~N}, 74.8439 \mathrm{E}$ \\
\hline Belale tank & 2524.2 & $14.7099 \mathrm{~N}, 74.8472 \mathrm{E}$ \\
\hline Basavana tank & 3808.5 & $14.7246 \mathrm{~N}, 74.8399 \mathrm{E}$ \\
\hline Shindigere tank & 2150.0 & $14.7082 \mathrm{~N}, 74.8501 \mathrm{E}$ \\
\hline Hanmanth Devara tank & 5733.4 & $14.7139 \mathrm{~N}, 74.8434 \mathrm{E}$ \\
\hline Bekkina Jaddi tank & 849.8 & $14.7236 \mathrm{~N}, 74.8503 \mathrm{E}$ \\
\hline $\begin{array}{l}\text { Kelagina Bommanalli } \\
\text { tank }\end{array}$ & 69.9 & $14.6839 \mathrm{~N}, 74.8253 \mathrm{E}$ \\
\hline Kadave \#1 tank & 1352.9 & $14.6741 \mathrm{~N}, 74.8222 \mathrm{E}$ \\
\hline Kadave \#2 tank & 345.8 & $14.67195 \mathrm{~N}, 74.8170 \mathrm{E}$ \\
\hline Bommanalli tank & 2753.7 & $14.6771 \mathrm{~N}, 74.8263 \mathrm{E}$ \\
\hline Konkana tank & 1588.7 & $14.6841 \mathrm{~N}, 74.8217 \mathrm{E}$ \\
\hline Golikoppa tank & 1635.1 & $14.7054 \mathrm{~N}, 74.8419 \mathrm{E}$ \\
\hline Ashisara tank & 1187.9 & $14.6916 \mathrm{~N}, 74.8258 \mathrm{E}$ \\
\hline Total & 100898 & \\
\hline
\end{tabular}

As seen from land cover map in Figure 1-3 of Chapter 1, the tanks are utilized to irrigate rice paddy, areca nut, and coconut, as well as other crops grown within the orchard such as black pepper, banana, and sugarcane. Many of the tanks were observed to be surrounded by areca nut orchards as to get the highest potential of surface water irrigation to the farms. However, the status of current irrigation tanks is overwhelmingly 
poor. Key informants expressed that overall tank performance has been on a progressive decline in virtually all the attributes that were studied. $82 \%$ of the tanks were affected by water shortage and only $37 \%$ of the tanks were restored in some form during this same time period. Four of the tanks had completely dried down in 2016 for their first time in their history. Furthermore, $75 \%$ of the tanks had a significant buildup of silt and debris that negatively affected their storage potential. These factors incentivized community engagement in restoring three of the tanks, with investments of up to 5 Lakhs (Rs. $500,000)$ being made by groups of farming households.

The current alternative uses for the tanks were primarily for wildlife habitat, along with fishing and washing animals to a lesser extent. Farmers expressed interest in investing the capital costs to implement small scale fisheries for supplemental income but were discouraged by the current available water resources and conditions of these tanks. The deteriorated tanks have also been resulting in increased fauna presence on farms consuming the produce, and thus allowing less profit for the farmers. The need for development of restoration management for these tanks was apparent and consistent throughout the full study area.

Figures 2-1 and 2-2 give examples visual representations of the various sizes and health of the irrigation tanks. Figure 2-1 focuses on the tanks that were observed and found to have low performance and high need for restoration. Kelagina Bommanalli tank (a) is the smallest tank, measured with a volume of approximately $70 \mathrm{~m}^{3}$. Malenalli tank (b) was one of the only tanks that had a complete dry down during the dry season when it was observed, and it was found that this was the first time this particular tank had a complete dry down since its inception. Keresara tank (c) portrays a tank that is affected 
by high sediment loads that have displaced most of its potential water volume. Finally,

for Figure 2-1, Jaanamaki tank (d) provides an example of a tank that is also inundated with high nutrient and sediment loads, thus producing large amounts of vegetation inside the tank.

Figure 2-1. Visual representations of tanks with various attributes leading to lower performance

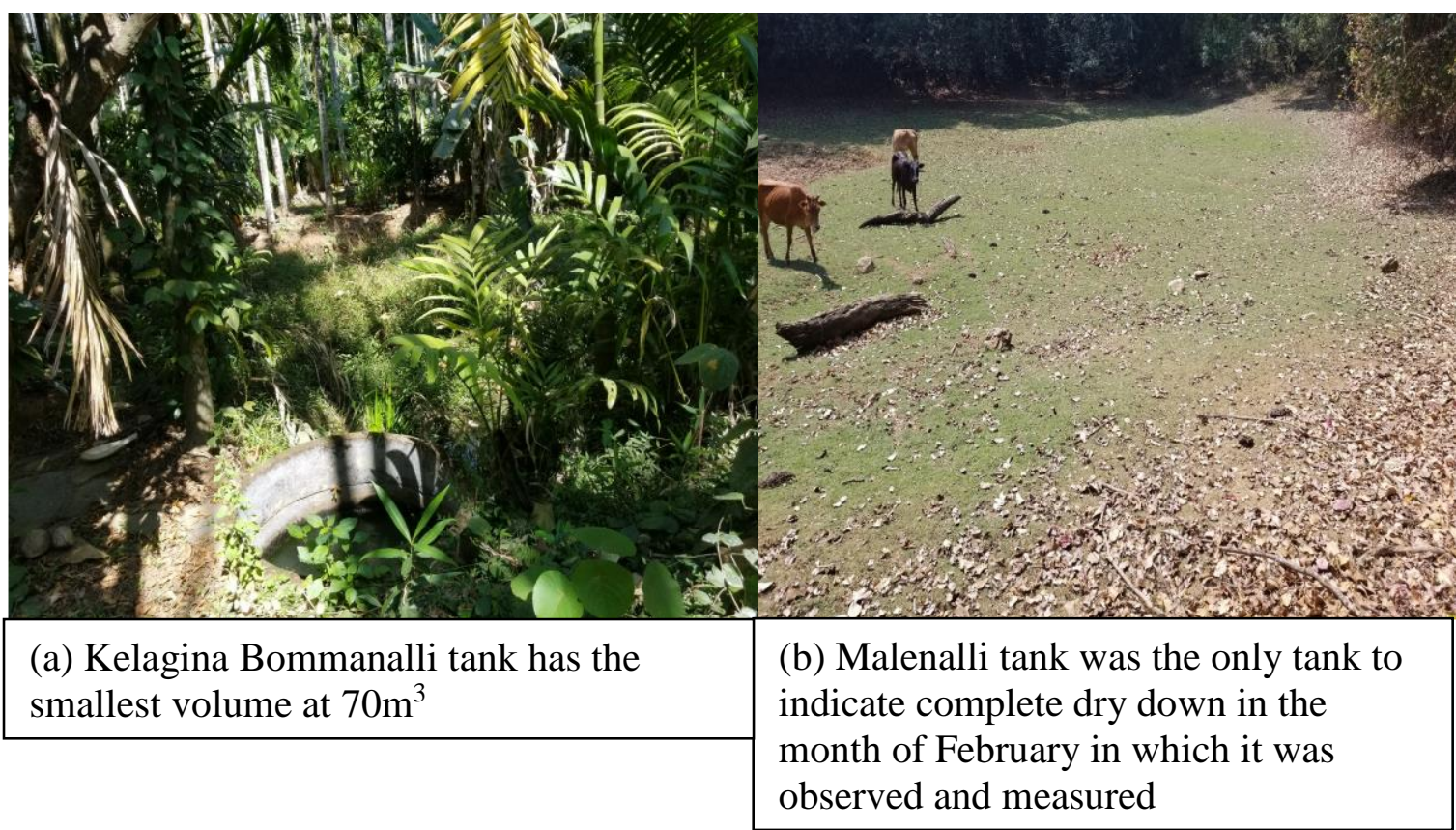

\begin{tabular}{|l|l|}
\hline &
\end{tabular}


Figure 2-2. Visual representations of tanks with various attributes leading to higher performance
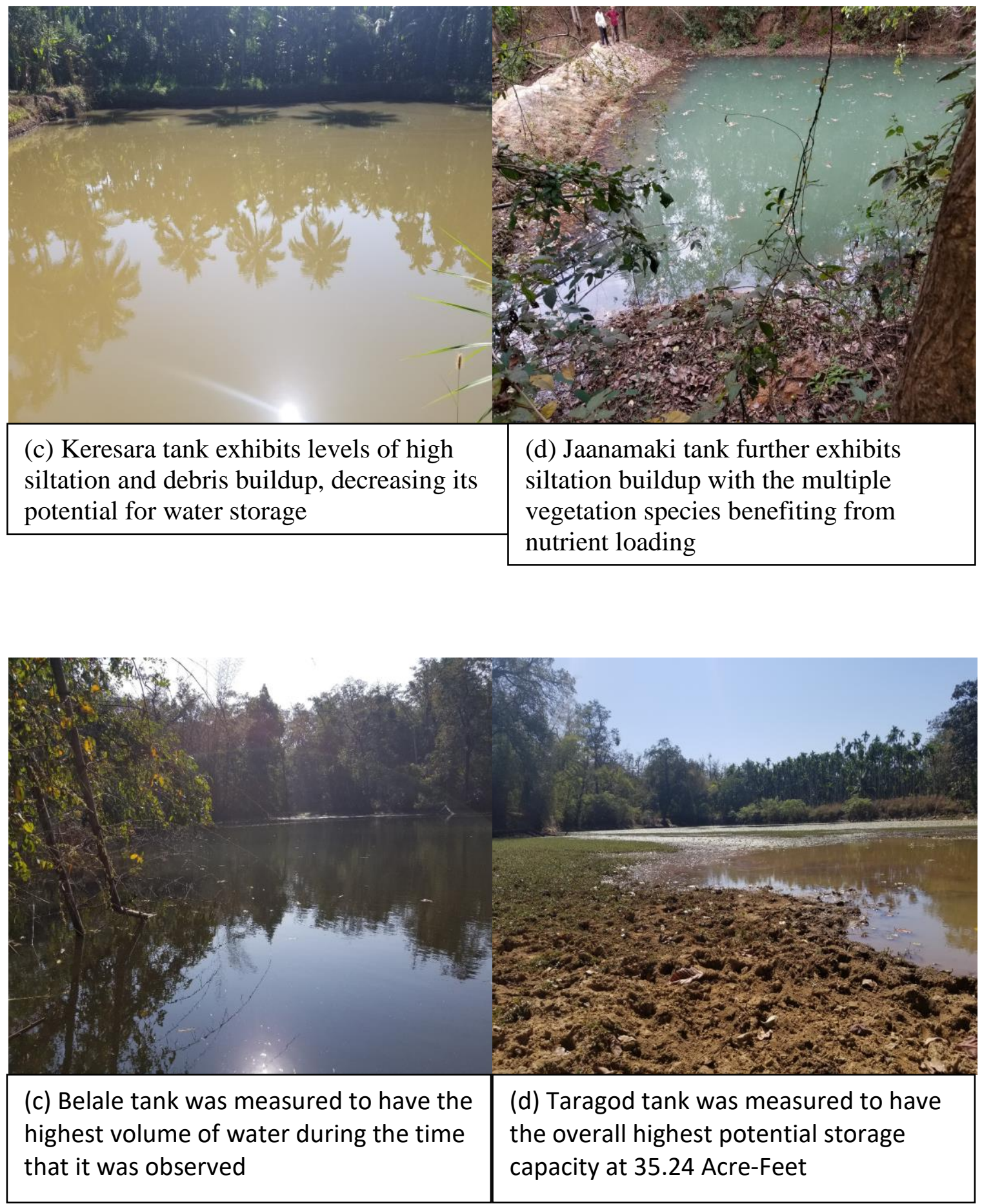
Figure 2-2 provides examples of tanks that led to higher performance values in the multi-criteria analysis. Bugadimane tank (a) is an example of a tank that showed little degradation from siltation and debris and was found to highly benefit the surrounding farmland. Devari Keri tank (b) gives a look at a newly de-silted tank, which provided the farmer with a reservoir of freshwater to recharge the groundwater table and supply sheet flow irrigation water to the surrounding cropland. Belale tank (c) was measured to have the most volume of water during the time that is was observed, acting as prime recharge as well as suitable habitat for various species of flora and fauna. Taragod tank (d) was like Belale tank in its volume and multi-attribute benefits and was measured to have the highest potential storage out of all tanks at 35.24 Acre-Feet.

\subsubsection{Multi-criteria (Indicator) Performance Values}

The indicator values show how each individual attribute affects the overall normalized performance values of each tank and can be found in the appendix.

Figure 2-3. Radar diagram of the normalized values for the Irrigation Tanks with highest composite values

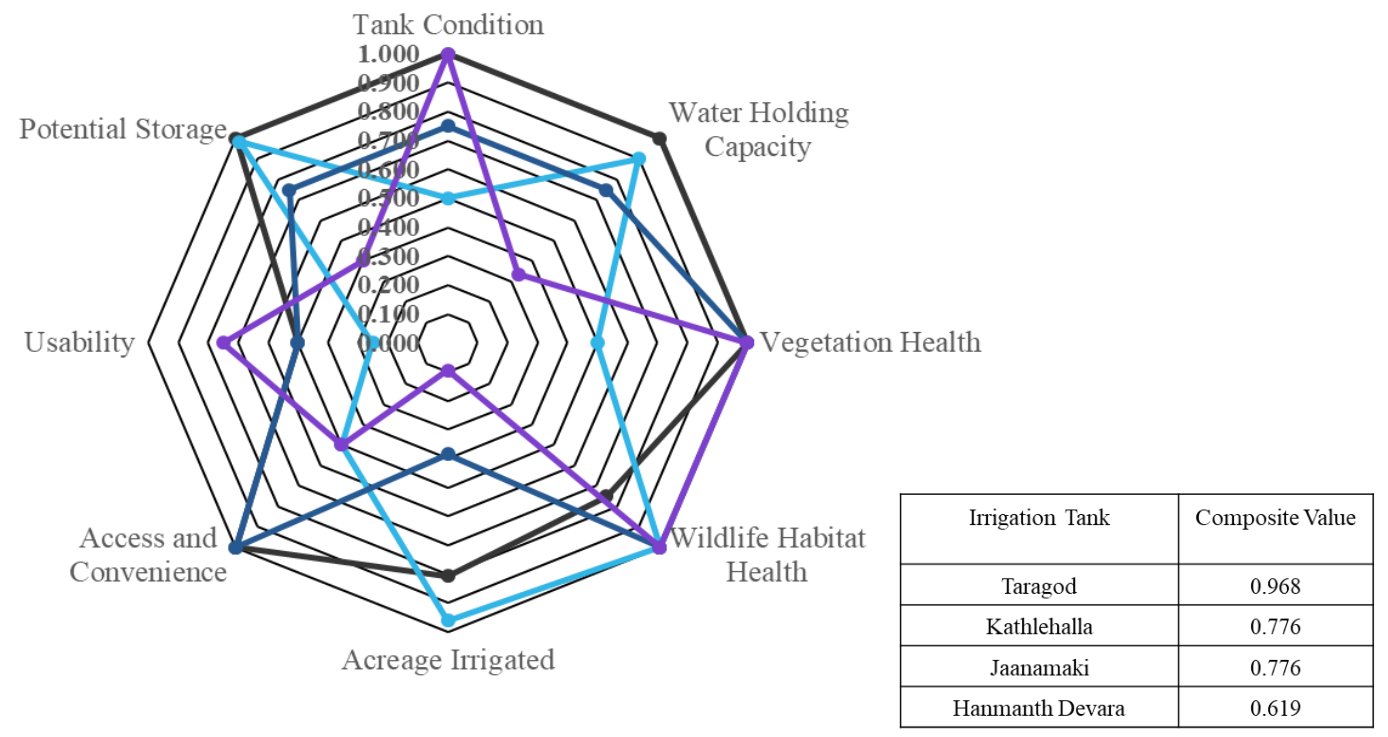


Figure 2-4. Radar diagram of the normalized values for the Irrigation Tanks with lowest composite values

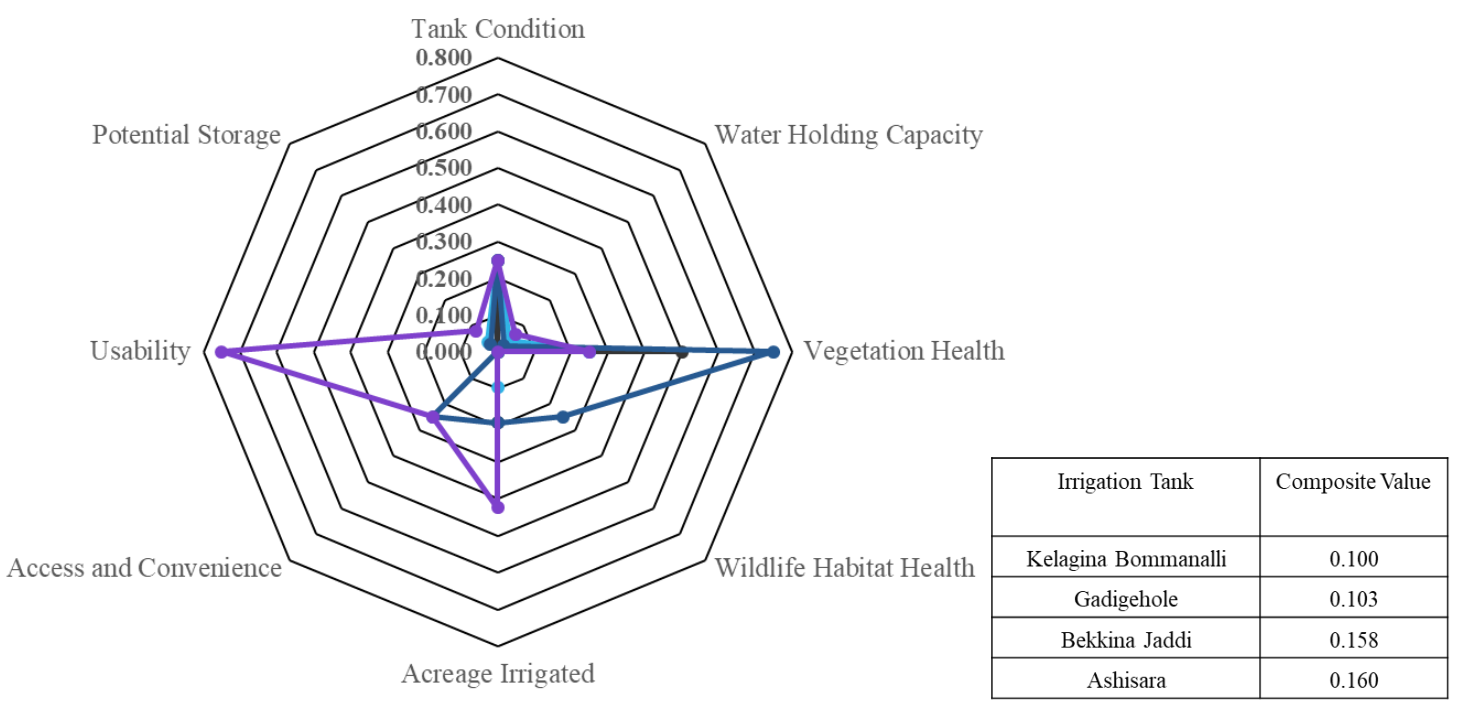

Figures 2-3 and 2-4 give the four highest composite values and lowest composite values, respectively, along with the corresponding normalized values for each attribute before integrating the AHP weights. There is a stark contrast between the normalized values of the lower-ranking and higher-ranking tanks. Usability and vegetation health were the only high scoring attributes in the low ranks of Figure 2-4 while Figure 2-3 shows maximized values for most of the attributes.

For overall attribute classification, the amount of mud and debris that was entering the irrigation tanks was an increasing concern for the potential benefits. Collection of the tank condition attributes for each individual tank showed an exceeding necessity for restoration efforts, as $70 \%$ of the tanks were given a score lower than a three on the qualitative scale. Furthermore, buildup of debris, sediment, and vegetation affected the of water holding capacity attribute, resulting in less volume for capture of rainfall. 
$50 \%$ of the tanks were observed to have a higher amount of debris that did not allow for the tank to capture as much of the rainfall in the monsoon season compared to its potential capacity. However, this did not affect the indicator of potential storage, due to this indicator being measured by the potential for the tank to capture water after restoration. The tanks with larger size and depth were given the highest quantitative value for potential storage.

For vegetation and wildlife habitat health, many of the irrigation tanks were surrounded by agricultural land, which was tended often by farmers and did not allow for a diverse potential for native flora and fauna to prosper. About $40 \%$ of all tanks were given a score less than three on the qualitative scale for these two indicators.

Finally, the access and convenience along with alternative usability indicators focused more heavily on the socioeconomic aspect of the tanks. $60 \%$ of the tanks were more than 500 meters off the road, usually surrounded by either dense forest land or areca orchard. This makes it difficult to reach for laborers and heavy machinery necessary to restore function, as well as to access the tanks for cultural or religious purposes.

Many of the tanks showed potential for alternative income sources such as integration of fisheries. More than $70 \%$ of the tanks were given a score higher than a 3 for usability on the qualitative scale, and many of the farmers were interested in attempting this in the event of restoration. The tanks all had very diverse characteristics, making each one unique to its village location along with the agricultural community that it provides water resources. The area and volume of each specific tank played a 
large role in its capacity to act as a source for alternative income, as all the tanks that were given the usability score above 3 had a water holding capacity of over 1 acre-foot.

\subsubsection{Analytical Hierarchy Process Weights}

The weights of different indicators are presented in Figure 2-3. It is evident that the role of tanks for agricultural purposes was the most significant factor, as the highest weights were $33.3 \%$ for potential storage, $26.1 \%$ for tank condition, and $17.4 \%$ for water holding capacity. This unsurprising result is reflective of the predominant agriculture present in the study area, which supports most of the population. Although, the ecological processes indicators that scored lower weights were still significant to the overall ecosystem health of the area.

Figure 2-5. Sustainability indicators and their respective weights, calculated using AHP method

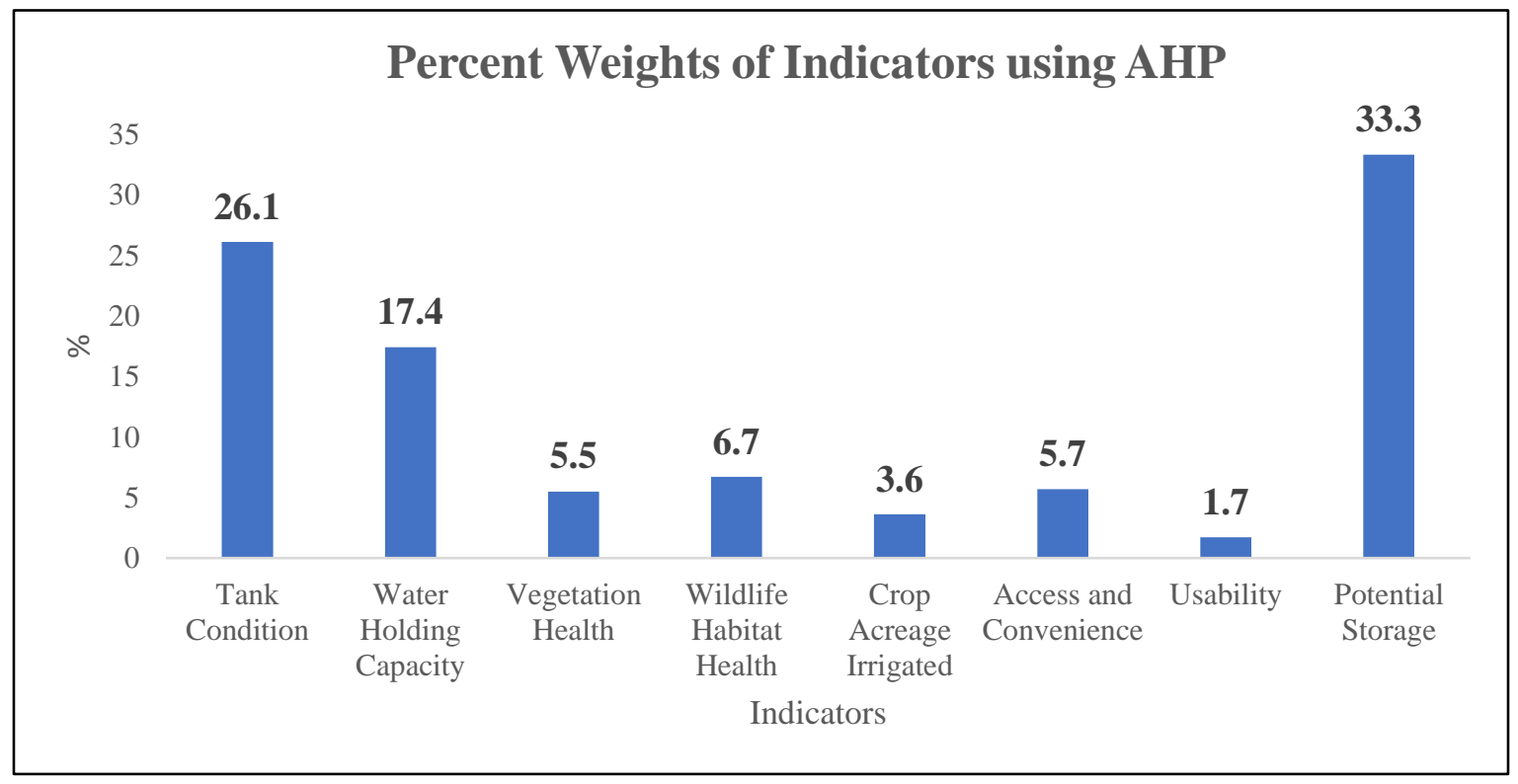

Interestingly, the indicator of crop area irrigated did not receive a high rank. Note that farmers were not allowed to directly extract water from tanks individually, and 
therefore, the indicator value of total crop area irrigated may not have received high weightage. However, they seemed to emphasize the total water holding potential of tanks which would ultimately increase the water available for agriculture, for instance, via groundwater recharge.

\subsubsection{Ranking of Irrigation Tanks}

The first system of ranking the tanks was accomplished through delineating the individual crop command areas. This criterion is significant due to cropping patterns being directly benefited by the command area of the irrigation tanks, depending on their size. The watershed delineation techniques in Chapter 1 allowed for a seamless application of the acreage irrigated for the tanks with the top 10 most crop acreage falling in their command area. Table 2-4 shows the largest crop area was 42.1 acres, which included rice paddy, areca orchard crops, and coconut plantations. This tank catchment area allows for a vast amount of agricultural land for low income farmers as the average farm size in the area is approximately only 1.12 acres. Restoration cost for $30 \%, 50 \%$, and $70 \%$ de-siltation scenarios are given in the table as well to express a monetary value needed to restore the top performing irrigation tanks to reach their potential.

Table 2-4. Top 10 tanks ranked by largest irrigated command area

\begin{tabular}{cccccc}
\hline $\begin{array}{c}\text { Rank } \\
\#\end{array}$ & Irrigation Tank & $\begin{array}{c}\text { Acreage } \\
\text { Irrigated }\end{array}$ & $\begin{array}{c}\text { Restoration } \\
\text { Cost 30\% } \\
(\text { Rs. })\end{array}$ & $\begin{array}{c}\text { Restoration } \\
\text { Cost 50\% } \\
\text { (Rs.) }\end{array}$ & $\begin{array}{c}\text { Restoration } \\
\text { Cost 70\% } \\
\text { (Rs.) }\end{array}$ \\
\hline 1 & Bugadimane tank & 42.1 & 66,191 & 110,318 & 154,446 \\
2 & Kathlehalla tank & 40.6 & 891,800 & $1,486,334$ & $2,080,867$ \\
3 & Keshinamane tank & 39.8 & 69,607 & 116,012 & 162,417 \\
4 & Kadave \#1 tank & 35.0 & 86,043 & 143,406 & 200,769
\end{tabular}




\begin{tabular}{|c|c|c|c|c|c|}
\hline 5 & Taragod tank & 34.2 & 604,794 & $1,007,991$ & $1,411,187$ \\
\hline 6 & Golikoppa tank & 32.6 & 103,992 & 173,320 & 242,649 \\
\hline 7 & Dalavaayi tank & 31.8 & 137,426 & 229,044 & 320,662 \\
\hline 8 & Ambalike tank & 27.8 & 341,785 & 569,642 & 797,499 \\
\hline 9 & $\begin{array}{c}\text { Kelagina } \\
\text { Bommanalli tank }\end{array}$ & 24.7 & 4,442 & 7,404 & 10,366 \\
\hline 10 & Kibbali tank & 23.9 & 13,948 & 23,247 & 32,546 \\
\hline & Total & 332.4 & $2,320,033$ & $3,866,723$ & $5,413,412$ \\
\hline
\end{tabular}

The second system of ranking tanks for restoration is based on the arithmetic composite index of the nine indicators. This system comes from a comprehensive perspective that includes the hydrological, ecological, and socio-economic attributes of the irrigation tanks. The tanks that scored the highest values are those that should be prioritized for restoration, as they bring about the highest overall benefits from each discipline. Table 2-5 shows the top ten tanks, and with a value of $0.968,0.776$, and 0.766 , the Taragod tank, Kathlehalla tank, and Jaanamaki tank received the highest three composite values, respectively, and thus has the highest potential to bring multiple use benefits to the study area if prioritized for restoration. The restoration costs are given at $30 \%, 50 \%$ and $70 \%$ de-siltation for these tanks as well.

Table 2-5. Top 10 tanks ranked by highest arithmetic composite index value

\begin{tabular}{cccccc}
\hline $\begin{array}{c}\text { Rank } \\
\#\end{array}$ & Irrigation Tank & $\begin{array}{c}\text { Composite } \\
\text { Value }\end{array}$ & $\begin{array}{c}\text { Restoration } \\
\text { Cost 30\% } \\
\text { (Rs.) }\end{array}$ & $\begin{array}{c}\text { Restoration } \\
\text { Cost 50\% } \\
\text { (Rs.) }\end{array}$ & $\begin{array}{c}\text { Restoration } \\
\text { Cost 70\% } \\
\text { (Rs.) }\end{array}$ \\
\hline 1 & Taragod tank & 0.968 & 604,794 & $1,007,991$ & $1,411,187$ \\
2 & Kathlehalla tank & 0.776 & 891,800 & $1,486,334$ & $2,080,867$ \\
3 & Jaanamaki tank & 0.776 & 452,715 & 754,525 & $1,056,335$
\end{tabular}




\begin{tabular}{cccccc}
4 & Hanmanth & 0.619 & 364,641 & 607,736 & 850,830 \\
& Devara tank & & & & \\
5 & Belale tank & 0.561 & 160,536 & 267,560 & 374,584 \\
6 & Ambalike tank & 0.548 & 341,785 & 569,642 & 797,499 \\
7 & Basavana tank & 0.547 & 242,222 & 403,704 & 565,186 \\
8 & $\begin{array}{c}\text { Appurayanajad- } \\
\text { di tank }\end{array}$ & 0.515 & 274,357 & 457,263 & 640,168 \\
9 & $\begin{array}{c}\text { Devari Keri } \\
\text { tank }\end{array}$ & 0.514 & 88,046 & 146,743 & 205,441 \\
10 & Emme tank & 0.478 & 304,299 & 507,165 & 710,031 \\
\hline & & Total & $\mathbf{3 , 7 2 5 , 2 0 0}$ & $\mathbf{6 , 2 0 8 , 6 6 7}$ & $\mathbf{8 , 6 9 2 , 1 3 4}$ \\
\hline
\end{tabular}

The third and final system of ranking the tanks comes from the perspective of equity. Utilizing the land cover map and crop command areas from Chapter 1, we measured for tank command areas that were composed of the highest percentage of rice paddy. Rice paddy is the primary form of subsistence agriculture in the study site and is a necessity for low income farmers for food security. The ranking of tanks that are composed of the highest percentage of rice paddy has been calculated and suggested for restoration prioritization on the basis that it will help the stakeholders that are most dependent upon tank irrigation.

As evident in Table 2-6, the Malenalli tank has over 50\% of rice paddy in its crop command area, so although it might not be the largest tank in terms of overall watershed area, its catchment is nonetheless utilized by many low-income farmers. Basavana tank and Bekkina Jaddi tank ranked second and third, respectively. The multiple restoration cost scenarios are given along with the top ten tanks covered by the most rice paddy. With these three forms of ranking the tanks can be used as a framework or guideline for 
decision makers on how to move forward with the management of the existing irrigation tank structures under their jurisdiction. It is important to note that although areca nut, banana, and pepper are significant crops in the command areas of these tanks, rice paddy covered more than $20 \%$ of the area in eight of the top ten tanks.

Table 2-6. Top 10 tanks ranked by highest rice paddy percentage in command area

\begin{tabular}{cccccc}
\hline Rank \# & Irrigation Tank & $\begin{array}{c}\text { Percentage } \\
\text { of Rice } \\
\text { Paddy (\%) }\end{array}$ & $\begin{array}{c}\text { Restoration } \\
\text { Cost 30\% } \\
\text { (Rs.) }\end{array}$ & $\begin{array}{c}\text { Restoration } \\
\text { Cost 50\% } \\
\text { (Rs.) }\end{array}$ & $\begin{array}{c}\text { Restoration } \\
\text { Cost 70\% } \\
\text { (Rs.) }\end{array}$ \\
\hline 1 & Malenalli Tank & 50.91 & 118,259 & 197,099 & 275,939 \\
2 & Basavana Tank & 46.01 & 242,222 & 403,704 & 565,186 \\
3 & Bekkina Jaddi Tank & 44.36 & 54,048 & 90,081 & 126,114 \\
4 & Appuryanajaddi Tank & 39.93 & 274,357 & 457,263 & 640,168 \\
5 & Choudi Tank & 30.85 & 184,822 & 308,036 & 431,251 \\
6 & Keresara Tank & 28.16 & 29,437 & 49,062 & 68,686 \\
7 & Manthaguli Tank & 25.84 & 47,760 & 79,601 & 111,442 \\
8 & Hanmanth Devara & 22.24 & 364,641 & 607,736 & 850,830 \\
& Tank & 17.49 & 452,715 & 754,525 & $1,056,335$ \\
9 & Jaanamaki Tank & 9.52 & 341,785 & 569,642 & 797,499 \\
\hline 10 & Ambalike Tank & Total & $\mathbf{2 , 1 1 0 , 0 5 2}$ & $\mathbf{3 , 5 1 6 , 7 5 3}$ & $\mathbf{4 , 9 2 3 , 4 5 5}$ \\
\hline
\end{tabular}

Table 2-7. Outcomes for prioritization

\begin{tabular}{|c|c|c|c|}
\hline Rank \# & MCDA Composite Value & Acreage Irrigated & Equity \\
\hline 1 & Taragod tank & Bugadimane tank & Malenalli Tank \\
\hline 2 & Kathlehalla tank & Kathlehalla tank & Basavana Tank \\
\hline 3 & Jaanamaki tank & Keshinamane tank & Bekkina Jaddi Tank \\
\hline
\end{tabular}




\begin{tabular}{|c|c|c|c|}
\hline 4 & Hanmanth Devara tank & Kadave \#1 tank & Appuryanajaddi Tank \\
\hline 5 & Belale tank & Taragod tank & Choudi Tank \\
\hline 6 & Ambalike tank & Golikoppa tank & Keresara Tank \\
\hline 7 & Basavana tank & Dalavaayi tank & Manthaguli Tank \\
\hline 8 & Appurayanajaddi tank & Ambalike tank & Hanmanth Devara Tank \\
\hline 9 & Devari Keri tank & Kelagina Bommanalli tank & Jaanamaki Tank \\
\hline 10 & Emme tank & Kibbali tank & Ambalike Tank \\
\hline
\end{tabular}

Green Tanks $=$ Shown on 2 rankings

Blue Tanks $=$ Shown on all 3 rankings

Table 2-7 was constructed using the prioritization frameworks from the previous three tables and shows specific overlapping tanks. Taragod, Kathlehalla, Jaanamaki, Hanmanth Devara, Basavana, and Appurayanajaddi tanks all fell in two of the top ten ranking frameworks, while Ambalike tank was categorized in all three.

Assuming the Minor Irrigation Department has an annual budget of Rs. 2,500,000 to allocate towards restoration of irrigation structures, we have constructed a prioritization framework in Table 2-8 that provides our recommendations for year 1 . We chose tanks that score high marks in all the three criteria-based lists (irrigated area, composite sustainability index, and equity-based) above. Tanks have been arranged in a systematic manner that will bring about the highest potential of benefits to the stakeholders. While the Minor Irrigation Department has proposed multiple large-scale irrigation projects for these panchayats, this framework acts as an alternative to allocating the budget back into the traditional form of irrigation. We will estimate with the assumption of the lowest de-siltation percentage at 30\% de-siltation. These tanks are, 
respectively, Taragod tank, Malenalli tank, Bugadimane tank, Keshinamane tank, Basavana tank, and Kadave \#1 tank.

Table 2-8. Year 1 scenario for priority restoration of irrigation tanks under budget constraints

\begin{tabular}{|c|c|c|c|c|c|}
\hline Year 1 & $\begin{array}{l}\text { Irrigation } \\
\text { Tank }\end{array}$ & Volume $\left(\mathrm{m}^{3}\right)$ & $\begin{array}{l}30 \% \text { De- } \\
\text { Silted }\left(\mathrm{m}^{3}\right)\end{array}$ & $\begin{array}{l}\text { Total Cost } \\
\text { (Rs.) }\end{array}$ & $\begin{array}{l}\text { Cumulative } \\
\text { Cost (Rs.) }\end{array}$ \\
\hline & Taragod Tank & 26,085 & 7,825 & $1,659,068$ & $1,659,068$ \\
\hline & $\begin{array}{l}\text { Malenalli } \\
\text { Tank }\end{array}$ & 2,267 & 680 & 144,181 & $1,803,250$ \\
\hline & $\begin{array}{l}\text { Bugadimane } \\
\text { Tank }\end{array}$ & 634 & 190.33 & 40,350 & $1,843,600$ \\
\hline & $\begin{array}{c}\text { Keshinamane } \\
\text { Tank }\end{array}$ & 834 & 250 & 53,040 & $1,896,641$ \\
\hline & $\begin{array}{c}\text { Basavana } \\
\text { Tank }\end{array}$ & 5,804 & 1,741 & 369,146 & $2,265,788$ \\
\hline & $\begin{array}{c}\text { Kadave \#1 } \\
\text { Tank }\end{array}$ & 3,092 & 927 & 196,695 & $2,462,483$ \\
\hline & & & \multicolumn{2}{|c|}{ Total Budget Allocated } & $2,500,000$ \\
\hline
\end{tabular}

\subsection{CONCLUSION}

The agroecosystem and catchment areas are the main determining factors of water distribution and movement in our study area, and therefore, an objective and sustainable water resource management decision must consider landscape level measurements of hydro- and socio-economic attributes. We have integrated remote sensing and ArcGIS techniques with standard multi-criteria analysis of natural resources applied to traditional tank irrigation systems. 
The results of this work allow for multiple attributes of irrigation tanks to be simultaneously weighted and evaluated by decision makers and stakeholders in the process of fulfilling different societal objectives. The performance of the irrigation tanks in this study area have been declining over the years and demand for alternative resource management is steadily increasing within the community. The rural communities in the study area and in many other agricultural areas of Karnataka are in need of efficient management of the existing irrigation tanks to bring the tanks back to satisfactory performance levels.

Although the performance is diminishing, the potential for multiple use advantages is still substantial and should not be neglected. While irrigation is the key variable in the assessment of irrigation tanks, other output values, such as benefits to social forestry, fisheries, livestock, and native species were analyzed in this study. This in turn raises the total value of output for irrigation tanks, rather than the mainstream perspective of explicitly collecting data on revenue from water resource extraction and agricultural production (Shah \& Raju, 2001).

The concept of tanks primarily serving as flow irrigation structures will make these systems less effective and neglected even further by decision makers. We estimated the surface runoff of the study area, which can be partially captured by traditional irrigation tanks provided they are managed well. Decisions can be made based off of how a percentage of runoff can be captured and conserved through the restoration of irrigation tanks, based on factors such as the slope and flow direction.

Realistically, there are superior alternatives to tanks as irrigation structures, meaning that the other services that tanks provide need to be given more value. This is 
the argument for utilizing of our multi-variable decision analysis approach that will allow for decision makers to utilize variables that would have otherwise been unaccounted for. This includes the structural condition of the tank, vegetation health, wildlife habitat health, and potential of usability for alternative sources of income. These attributes are weighed against traditional significant attributes for agriculture productivity like water storage and crop area irrigated in order to recognize the multiple stakeholders with conflicting interests. The institutions that participate in the management of these irrigation systems will ultimately decide on how this information might be applied to both the local study area as well as water resource management scenarios for other agricultural watersheds throughout the country.

Irrigation tank management and maintenance is dispersed over a variety of stakeholders and institutions, most notably the minor irrigation department and Zilla Panchayat division. The Zilla Panchayat (ZP) is an administrative body that has jurisdiction over the irrigation tanks in the study region that fall under five acres in area. The allocated budget for tank restoration depends on the demands of elected members and the availability from the total budget of the ZP. This means that the current status of decision making of tank restoration falls with four members that vote for specific village tanks. Our results could provide a framework for these governing officials and give an objective analysis into prioritizing the tanks for budget allocations.

Furthermore, The Karnataka Community-Based Tank Management Project would also benefit from this scientific-based approach to improvement and management of tanks. This project began in 2002 and covers over 2,700 existing tanks throughout nine districts in Karnataka. This project could utilize the methodology for a larger number of 
tanks and be able to reach its objective of promoting rural livelihoods and reducing poverty with proper distribution of resources for restoration.

Despite the deteriorating and outdated status of irrigation tanks, the restoration and maintenance of these structures still stands as the most cost-effective strategy to capture rainfall during the monsoon season and allow for recharge of the groundwater table during the dry season. Low income farmers that depend on tanks have very high stakes in these irrigation structures and will benefit from proper restoration. These same individuals are not satisfied with the existing management and require a scientifically backed framework to augment the decision-making process of restoration. Hence, there is a vital need to rejuvenate the chain of irrigation tanks through effective modernization techniques that will improve the channel of water resources between cascading irrigation tank systems.

Due to limited time and resources for field work, further analysis is necessary to incorporate the value of quantitative groundwater recharge in future studies on modernizing tank irrigation in rural agricultural communities of Karnataka, India. However, this comprehensive analysis has increased the scale for evaluation of irrigation tanks both within the study area and for watersheds throughout India by highlighting a holistic approach through hydrological, ecological, and socioeconomic benefits that irrigation tanks provide. More emphasis should be given to support a wider range of attributes in the decision-making process that could lead to different income-generating practices, increased ecological health, and a potential for greater agricultural outputs. 


\subsection{REFERENCES}

Anbumozhi, V. K. M. and E. Y. (1995). Sustaining Agriculture through Modernization of Irrigation Tanks: An Opportunity and Challenge for Tamilnadu, India.

Agricultural Engineering International, III, 1-12.

Anbumozhi, V., Matsumoto, K., \& Yamaji, E. (2001). Towards improved performance of irrigation tanks in semi-arid regions of India: Modernization opportunities and challenges. Irrigation and Drainage Systems, 15(4), 293-309.

https://doi.org/10.1023/A:1014420822465

Arumugam, N., Mohan, S., \& Ramaprasad, R. (1997). Sustainable development and management of tank irrigation systems in south india. Water International, 22(2), 90-97. https://doi.org/10.1080/02508069708686676

Balasubramanian, R., \& Govindasamy, R. (1991). Ranking irrigation tanks for modernization. Agricultural Water Management, 20(2), 155-162. https://doi.org/10.1016/0378-3774(91)90013-9

Balasubramanian R. and K.N.Selvaraj (2003), Poverty, Private Property and Common Pool Resource Management: The Case of Irrigation Tanks in South India, SANDEE Working Paper, No. 2-03, Kathmandu, Nepal, August.

Balasubramanian, R. (2006). Institutional Landscapes in Common Pool Resource Management: A Case Study of Irrigation Tanks in South India. 1-29.

Chandrasekaran, K., Devarajulu, S., \& Kuppannan, P. (2009). Farmers' Willingness to pay for irrigation Water: A case of tank irrigation systems in South India. Water (Switzerland), 1(1), 5-18. https://doi.org/10.3390/w1010005

Egadeesan, M. J., \& Koichi, F. U. (2011). Deterioration of the Informal Tank Institution in Tamil Nadu: Caste-based Rural Society and Rapid Economic Development in India. Southeast Asian Studies, 49(1), 93-123.

Elbarkouky, M. M. G. (2012). A Multi-Criteria Prioritization Framework (MCPF) to Assess Infrastructure Sustainability Objectives. Journal of Sustainable Development, 5(9), 1-13. https://doi.org/10.5539/jsd.v5n9p1

Heltberg, R. (2001), 'Determinants and impact of local institutions for common resource management', Environment and Development Economics, 6: 183-208.

IPCC (2007). Climate Change 2007: The Physical Science Basis. Contribution of Working Group I to the Fourth Assessment Report of the Intergovernmental Panel on Climate Change, Geneva, Switzerland, p 104. 
Kajisa, K., Palanisami, K., \& Sakurai, T. (2007). Effects on poverty and equity of the decline in collective tank irrigation management in Tamil Nadu, India. Agricultural Economics, 36(3), 347-362. https://doi.org/10.1111/j.15740862.2007.00212.x

Kiker, G. A., Bridges, À. T. S., Varghese, À. A., \& Thomas, P. (2005). Application of Multicriteria Decision Analysis in Environmental Decision Making. Integrated Environmental Assessment and Management, 1(2), 95-108.

Kolavalli, S., \& Brewer, J. D. (1999). Facilitating user participation in irrigation management. Irrigation and Drainage Systems, 13(3), 249-273. https://doi.org/10.1023/A:1006211725291

Krajnc, D., \& Glavič, P. (2005). A model for integrated assessment of sustainable development. Resources, Conservation and Recycling, 43(2), 189-208. https://doi.org/10.1016/S0921-3449(04)00120-X

Lipton, M., Litchfield, J., \& Faurès, J. M. (2003). The effects of irrigation on poverty: A framework for analysis. Water Policy, 5(5-6), 413-427. https://doi.org/10.1002/2016JD025945

Lise, W. (2000). 'Factors influencing people's participation in forest management in India', Ecological Economics, 34: 379-392.

Mavrommati, G., Borsuk, M. E., \& Howarth, R. B. (2017). A novel deliberative multicriteria evaluation approach to ecosystem service valuation. Ecology and Society, 22(2). https://doi.org/10.5751/ES-09105-220239

Mosse, D. (1997). The symbolic making of a common property resource: History, ecology and locality in a tank-irrigated landscape in South India. Development and Change, 28(3), 467-504. https://doi.org/10.1016/S0141-8130(00)00130-6

Mosse, D. (1998). Making and Misconceiving Community in South Indian Tank Irrigation. International Association for the Study of Common Property (IASCP), $1-20$.

Mosse, D., \& Nelson, N. (1995). Local institutions and power: the history and practice of community management of tank irrigation systems in south India. Power and Participatory Development: Theory and Practice, 144-156. Retrieved from http://www.redverslee.org/Micropolitics/February_5_files/Mosse 1995.pdf

Munasinghe, M., 1992. Towards Sustainable Development: The Role of Environmental Economics and Valuation (The World Bank Environment Paper Number 3). The World Bank, Washington, DC. 
Nadkarni, M.V. (2000), 'Poverty, environment, development: A many-patterned nexus', Economic and Political Weekly, 1184-1190.

Oppen, von M. Rao, K. V. (2000). History and Economics of Tank Irrigation in SemiArid Tropical India. 3.

Ostrom, Elinor (2000). 'Collective Action and the Evolution of Social Norms', Journal of Economic Perspectives, 14(3): 137-158.

Palanisami, K. \& Easter, K. W. (1984). Tank irrigation in India and Thailand: Problems and prospects, ODIIrrigation Management Network, Network Paper 10e, London, England.

Palanisami, K. (2006). Sustainable Management of Tank Irrigation Systems in India. 3440.

Palanisami, K. 1993. Optimization of Cropping Patterns in Tank Irrigation Systems in Tamil Nadu, India. Systems Approaches for Agricultural Development, 413-425.

Palanisami, K., \& Flinn, J. C. (1988). Evaluating the performance of tank irrigation systems. Agricultural Systems, 28(3), 161-177. https://doi.org/10.1016/0308$521 X(88) 90049-2$

Palanisami, K., \& Meinzen-Dick, R. (2001). Tank performance and multiple uses in Tamil Nadu, South India. Irrigation and Drainage Systems, 15(2), 173-195. https://doi.org/10.1023/A:1012927722965

Palanisami, K., Gemma, M., \& Ranganathan, C. R. (2008). Stabilisation value of groundwater in tank irrigation systems. Indian Journal of Agricultural Economics, 63(1), 126-134.

Palanisami, K.., Meinzen-Dick, R.., \& Giordano, M. (2010). Climate change and water supplies: Options for sustaining tank irrigation potential in India. Economic and Political Weekly, 45(26-27), 183-190. Retrieved from http://www.scopus.com/inward/record.url?eid=2-s2.084855916403\&partnerID=40\&md5=615d481c67fa968d9d14b6dacded7ef0

Proctor, W., and M. Drechsler. 2006. Deliberative multicriteria evaluation. Environment and Planning C 24(2):169. http://dx.doi. org/10.1068/c22s

Reddy, V. R., Reddy, M. S., \& Palanisami, K. (2018). Tank rehabilitation in India: Review of experiences and strategies. Agricultural Water Management, 209(April), 32-43. https://doi.org/10.1016/j.agwat.2018.07.013

Saaty T L (1980) The Analytic Hierarchy Process, McGraw Hill International. 
Sakthivadivel, R., Gomathinayagam, P., \& Shah, T. (2004). Rejuvenating Irrigation Tanks through Local Institutions. Economic and Political Weekly, 39(31), 35213526. https://doi.org/10.2307/4415350

Seleman, A., \& Bhat, M. G. (2016). Multi-criteria assessment of sanitation technologies in rural Tanzania: Implications for program implementation, health and socioeconomic improvements. Technology in Society, 46, 70-79. https://doi.org/10.1016/j.techsoc.2016.04.003

Shah, T., \& Raju, K. V. (2001). Rethinking rehabilitation: Socio-ecology of tanks in Rajasthan, north-west India. Water Policy, 3(6), 521-536. https://doi.org/10.1016/S1366-7017(02)00015-6

Shanmugam, C.R., and R. Sakthivadivel, "An Action Research Study on Modemisingna Tank Irrigation System in Tamilnadu;' Technical Report Centre for Water Resources, Anna University, Madras, India, 1988.

Shankari, U. (1991). Tanks: major problems in minor irrigation. Economic and Political Weekly, 26(39). Retrieved from http://www.jstor.org/stable/10.2307/41627025

Tiwari, D. N., Loof, R., \& Paudyal, G. N. (1999). Environmental-economic decisionmaking in lowland irrigated agriculture using multi-criteria analysis techniques. Agricultural Systems, 60(2), 99-112. https://doi.org/10.1016/S0308$521 X(99) 00021-$ 


\section{CHAPTER 3}

\section{A SOCIAL AND ECONOMIC ASSESSMENT OF A LIFT IRRIGATION PROJECT IN KARNATAKA, INDA}

\subsection{INTRODUCTION}

Research on development and effective investment in large-scale irrigation technology in India has progressively increased in the past decade as a result of poor water resource availability from monsoon periods (Ackermann 2012; Ashra \& Chakravarty, 2007; Batterbury 2001; Choudhury 2007; Choudhury et al. 2009; Mudrakartha et al. 2011; Reddy 2003; Tiwary 2009). These technological developments have been defined by multi-year plans to fund the construction of large dams and irrigation infrastructure throughout the country. While these projects introduce employment opportunities for rural populations and a possible solution for the water crisis, they are often overly ambitious and lack the planning and foresight for sustainable management (Gupta 2011).

To face these challenges, water use in rural agricultural systems has recently begun to develop with the concept of sustainable development. Loucks and Gladwell (1999) define sustainability as a specific set of systems that are designed and maintained to satisfy present and future objectives of a society, disregarding prejudice introduced by environmental, ecological, and hydrological factors. This concept can be applied to agriculture and water resources, as the objectives include practices that minimize environmental damage and water losses while maximizing crop production.

More specifically, objectives for agricultural systems with fluctuating water resources focus on adaptation of physical and biological variables to create economic 
efficiency with natural resources along with community participation in decision making (Ioris et al. 2008). This concept is coupled with the increasing demand for adequate water storage infrastructure in India to ensure proper management and construction strategies for modern irrigation projects.

Furthermore, these projects are vulnerable to the increasing fluctuations in climate variables such as precipitation and temperature. Future climate scenarios in India have expressed a high likelihood that surface flow (Vano et al. 2015), groundwater recharge (Crosbie et al. 2013), and overall water availability will be affected. The increasing demand for water from demographic and socioeconomic changes has resulted in predictions of $40 \%$ increase in groundwater withdrawal by the year 2050, compared with 2000 (Amarasinghe et al. 2007). However, these estimates are likely significantly underexaggerated when compared with the added unknown changes brought on by the variables of precipitation and temperature (Holman et al. 2012).

India is the largest user of groundwater resources at 250 billion $\mathrm{m}^{3} / \mathrm{year}$ (Aquastat 2010), and changes to surface runoff will further impact the water table depletion (Scott 2013). Approximately 90 million rural households are solely dependent on groundwater extraction, which has been heavily supported through government policies that have supplied rural farmers with subsidized pumps and electricity (Zaveri et al. 2016). These policies, along with a decline in soil quality and sharp differences in the agrarian class hierarchy, have resulted in water crises and stagnation of cultivable land for approximately 120 million hectares (Agoramoorthy et al. 2009; Biswas \& Hartley, 2017).

The regulation of groundwater policies through the states have shown great difficulty with enforcement and implementation primarily on the demand side of 
groundwater operation. Farmers in many states have abused this lack of enforcement through construction of bore wells that have not been registered through the state (Shah, 2014). Budgetary constraints have also added to the problem, as policies that favor watersaving agricultural technology and community participation of groundwater resources have commonly see lack of financial and regulatory support (Narayanamoorthy, 2004). With the supply side of groundwater resource management, multiple strategies have been attempted, including groundwater recharge structures and more accessible surface irrigation (Foster et al. 2003). However, recent solutions to the water crisis in India continue to fall short of the effective goals that policymakers originally sought (Chindarkar \& Grafton, 2019).

Despite the ambiguous and incomplete nature of existing irrigation projects, legislators are still pushing efforts to modernize irrigation development with the understanding that a significant amount of India's rural population relies on agriculture as their main source of income (Meher 2009). Many of the rural communities in India do not have a large potential for implementation of large-scale irrigation infrastructure due to the high cost of investments. The inconsistent distribution of water resources in the monsoon season based on geographical proximity has shown to be unreliable in bringing food security and agricultural productivity on its own to these communities. Further research must be done to push infrastructure for application of controlled quantities of water at managed time intervals for the rural farmers in India to prosper.

Kalle and Kasi (2016) explain the need for minimizing the gap between the intended goal of providing sufficient access to water and the realistic outcome. They, along with multiple other researchers, have analyzed the factors that are to blame for the 
successes and failures of different irrigation schemes throughout the country. Lift irrigation schemes (LIS) are one such system that have been closely examined for its irrigation potential. LIS rural development that has the goal of promoting benefits to poor and marginal farmers by transitioning infertile drylands into prolific agricultural area. The process involves water that is mechanically lifted from streams, rivers, or other water bodies using pump systems to be pushed to higher elevation and channelized into farmland (Kalle \& Kasi, 2016).

Many rural agricultural districts throughout India, including the Uttara Kannada district where our research has focused, do not have any other options other than LIS. However, LIS have been shown enhance irrigation potential if managed properly. For example, Agoramoorthy et al. (2009) has given evidence that lift irrigation schemes have brought employment opportunities and increased crop production to 20 villages and over 20,000 individuals located in Western India.

By considering the factors and variables associated with LIS, our research for Chapter 3 has focused on properly utilizing scientific methodology to evaluate the viability of a lift irrigation project that has been proposed in the state of Karnataka, India. Before the community was to implement cost intensive irrigation infrastructure, we argued that a science-based study on the economic potential of this LIS would allow for policymakers to formulate a more educated decision on how best to utilize irrigation budget allocations.

The specific objectives for this chapter are as follows, 
1. Assess the current agricultural productivity and household water use of the study area, with primary focus on the area directly benefitting from the proposed lift irrigation project

2. Evaluate household opinion and farmer perceptions of the proposed lift irrigation project

3. Evaluate economic viability of the proposed lift irrigation project utilizing Cost-Benefit Analysis and Net Present Value procedures

\subsection{LITERATURE REVIEW}

Within the past 50 years, the Government of India (GOI), along with state governments, has introduced projects that have the potential to irrigate 73 million hectares but are only utilizing around $78 \%$ of this. India increased their crop production from 50 million tons in the 1950 's to roughly 200 million tons in the early 2000 's (National Water Policy 2002). Due to the increase in demand of water for domestic, industrial, environment, navigation, and power industries, alternative sources for irrigation of surface water are quickly becoming popular options. Given this new shift, there is a significant necessity for better management strategies of medium and major irrigation projects (Choudhury 2007).

With proper management comes proper financing, economic policies and adjustment to current programs. Since the 1990's, India has experienced constraints on budget allocation towards the irrigation sector, while $70 \%$ of the maintenance and operation budget is allocated to initial cost of establishment and labor (Swain 1998). The irrigation sector had not implemented management strategies to follow the construction of physical infrastructure until the 1980's (Swain \& Das, 2008). Major states have shifted 
further towards the practice of ongoing management by making systematic changes to local institutions and organizations regarding farmers participation in irrigation. For example, Swain \& Das (2008) explain that states such as Karnataka, Andhra Pradesh, and Tamil Nadu are putting more importance on the formation of Water Users Associations (WUAs) to decentralize the management and include participants stemming from a variety of stakeholder backgrounds.

Objectives and criteria for irrigation project design and management can vary widely between individuals, groups, departments, and institutions. Many questions are to be considered including who are the beneficiaries, what is the projected productivity of water, how will equity play a role in resource allocation, how will sustainability be integrated with long-term stability and management, and how will livelihoods be affected in a population (Chambers 1982).

The views of the various stakeholders must be collected for the project to be productive. For rural agricultural areas with proposed irrigation schemes, the stakeholders include landless laborers, farmers, irrigation engineers, agricultural engineers/economists, and political players. The criteria for landless laborers are whether the proposed project will bring increased labor demand and as a result, more potential wage earnings. For farmers, the criteria are increased predictable and timely water delivery to the farmland at low cost. For irrigation engineers, the criteria are that of effective water delivery from the source of the barrage to the outlet. Finally, for agricultural engineers/economists, the criteria are effective application of the irrigation water from the outlets to the farmland, as well as high crop production and income (Chambers, 1974). 
With the necessary criteria being accounted for, irrigated agriculture has a high potential to bring a plethora of benefits to India's societies. Much irrigation research focuses on the specific benefits that can be brought to rural communities that inhabit isolated wilderness regions in South India's drylands (Jha 2002) as these farmers generally hold large tracts of land with minimal irrigation infrastructure (Agoramoorthy \& Hsu, 2015). Farmland in these areas is commonly found at higher elevations than the surrounding rivers and the only option for dealing with water delivery in this scenario has been to lift water from rivers directly or with the construction of check dams built within the rivers to upland farms (Kalle \& Kasi, 2016).

\subsubsection{Economic Impacts}

Briscoe (1996) describes irrigation economics as having three economic measures of water use, which are (1) the opportunity cost, (2) the use cost and (3) the marginal value. The opportunity cost is defined as the value that is set on irrigation water for its next best alternative use. The use cost burden is put on the user in the form of collection and distribution of water to the cropland. Marginal value is simply the potential for productivity of the water for irrigation use. If these measures are integrated in synchrony, irrigation projects would allow for low cost and high productivity, although there is much difficulty in achieving this due to the price inelasticity of irrigation water (Shah et al. 2008).

The controversy behind irrigation economics is pushed forward in India with public irrigation systems becoming increasingly marginalized against private well expansion in rural agricultural communities (Barker \& Molle, 2004). Public irrigation systems including irrigation tanks and canals are declining as the area irrigated with 
private tube wells has risen in the same time period. For instance, the GOI states that the source of irrigation for monsoon season crops (kharif) and dry season crops (rabi) were $69 \%$ and $76 \%$ tube wells, respectively (NSSO 2005). Table 3-1 expresses the insignificance of canal irrigation on its own, where Shah et al. (2006) gathered data through International Water Management Institute (IWMI) with farmers throughout India in 2002 on individual cropland irrigation behavior. The underlying economics associated with the large-scale changes to the mode of delivery for irrigation water to crops shows the consequences of moving away from public irrigation systems on small and marginalized farmers.

Table 3-1. Irrigation sources in the region of India based off 2002 IWMI survey results (Shah et al. 2006)

\begin{tabular}{|c|l|l|l|l|l|l|}
\hline Region & $\begin{array}{l}\text { Cultivable land } \\
\text { of sample } \\
\text { farmers (ha) }\end{array}$ & $\begin{array}{l}\text { Rainfed } \\
(\%)\end{array}$ & $\begin{array}{l}\text { Strictly } \\
\text { under } \\
\text { canal } \\
\text { irrigation } \\
(\%)\end{array}$ & $\begin{array}{l}\text { Strictly } \\
\text { under } \\
\text { groundwater } \\
\text { irrigation } \\
(\%)\end{array}$ & $\begin{array}{l}\text { Combined } \\
\text { use of } \\
\text { ground and } \\
\text { canal water } \\
(\%)\end{array}$ & $\begin{array}{l}\text { Other } \\
\text { Sources }\end{array}$ \\
\hline India & 150,534 & 57.1 & 2.7 & 32.8 & 5.0 & 2.4 \\
\hline
\end{tabular}

A multitude of researchers have focused on the monetary returns and benefit/cost ratio with an equitable approach for irrigation management projects in agriculture (Nawalawala 1994; Srivastava et al. 2000; Goel \& Kumar, 2005). The benefits that are involved in the economic analyses usually have a long-life span when it comes to water management projects. Consistent and full irrigation conditions can bring about potential 
for higher yields, establishment of new crops, and expansion of cropland (Sishodia et al. 2018).

The costs that are involved pertain to initial construction along with annual operation and maintenance for the actual irrigation scheme, as well as cost of establishment and maintenance of new cropland. The benefit/cost ratio allows for the assessment of a projects benefits versus costs to determine its economic viability, whereas if the ratio is more than one, then it is considered a viable project (Linsely \& Franzini, 1979; Tung 1992; Tiwari \& Goyal, 1998).

For example, Goel \& Kumar (2004) utilized the benefit/cost ratio on the construction of rainwater harvesting structures in the Soan river catchment located in the northwest Himalayas. They found that the benefits brought on by increased irrigation to the grain yield of wheat and maize resulted in a ratio above 1. Additionally, cost recovery would occur within four years if the larger structures were to be constructed.

Sishodia et al. (2018) also utilized the benefit/cost ratio in determining the effects of future climate scenarios both with and without management strategies in the Krishna River basin of South India. These strategies included increased dispersed water storage, flood to drip irrigation conversion, and no intervention, which fell under different scenarios of climate trends. This economic analysis method has the potential to be easily integrated into different construction projects with varying objectives and goals.

\subsubsection{Social Impacts}

The socio-economic potential for publicly managed irrigation systems moving into the $21^{\text {st }}$ century does not have the capacity to reproduce the same productive output that was established in the past. Reasons for this decreased impact include the fact that in 
the past there was no alternative to collective action, collective action was more aggressively enforced, there were few alternative sources of income other than farming, and well irrigation had a high cost of establishment (Burt \& Styles, 1999). Rural agrarian conditions in the past did not have the issue of exponential population increase, and as such, public irrigation projects were properly aligned with the goals, objectives, and criteria of their respective management authority.

Post-colonial India has transitioned into a new agricultural regime that affects the economic and social aspects of all the stakeholders. For further context, Table 3-2 gives a summary of the socio-economic and technical factors that play key roles in the irrigation management of modern India. As shown, the burden of organization of irrigation falls upon the individual farmer, rather than a participatory community like pre-colonial times. The governing bodies that enforce regulations over rural agricultural communities have become more decentralized and less efficient over time, and demographic changes in agricultural societies are resulting in a shift away from subsistence farming. Finally, irrigation technology has further incentivized privatized wells through lower costs and an easier access to irrigation infrastructure (Mukhedrji et al. 2009).

Table 3-2. Socio-economic and technical variables and their defined roles for surface irrigation management in modern day India (Mukhedrji et al. 2009)

\begin{tabular}{|c|c|}
\hline Conditional Variable & Surface Irrigation in Modern India \\
\hline Irrigation Organization & Commonly managed by individual farmers \\
\hline Quality of the governing state & Weak state and local authority \\
\hline
\end{tabular}




\begin{tabular}{|c|c|}
\hline Quality of the agricultural society & $\begin{array}{c}\text { Increased off-farm opportunities, different } \\
\text { irrigation timing, variety of crops that have high } \\
\text { market value }\end{array}$ \\
\hline Quality of irrigation technology & $\begin{array}{c}\text { Introduction of mechanical pump sets and low-cost } \\
\text { pipes for transportation and distribution of surface } \\
\text { and groundwater }\end{array}$ \\
\hline Demographics & $\begin{array}{c}\text { Exponential increase in 1950 both in urban and } \\
\text { rural settlements, larger demand for commercial } \\
\text { agriculture, shifting from subsistence practices }\end{array}$ \\
\hline
\end{tabular}

Various research studies have shown that the physical condition of the irrigation infrastructure also heavily relies on a social component, such as the farmer-agency relationship (Duewel, 1995; Huppert \& Wolff, 2002). Synergy between the farmers and the agency will allow for both an enhancement in infrastructure along with increased system performance. Due to this, irrigation infrastructure is going through a period of reform where criteria are attempted to be met for all parties involved (Shah 2008). Researchers have been utilizing survey methods to gather qualitative data on farmer's perceptions of current irrigation to better reach this goal (Molden, 2007; Mukherji et al. 2009; Kimmich, 2013).

\subsection{METHODOLOGY}

The study area utilized for Chapter 3 is the same as in Chapters 1 and 2 and can be referred to in Table 1-1.

\subsubsection{Overview of Data Collection}

The District Minor Irrigation Department is proposing to commission a lift irrigation project in the study area. This will be executed by lifting water from a local 
river during the rainy season, building a network of mountain-top storage tanks and conveyance structures to connect 10 minor irrigation tanks, and supply water to these tanks during the dry season. Project completion will require considerable government investment. The data collected on the construction and maintenance costs can be seen in Table 3-3, and includes cost of pumps and pump houses, delivery chambers and pipes, as well as electricity and labor, was collected from the State Minor Irrigation Department.

Table 3-3. Costs of construction and maintenance for proposed lift irrigation project in Lakhs (Source: Government of Karnataka, Minor Irrigation Department)

\begin{tabular}{cc}
\hline Costs of Construction/Maintenance & Rs. (Lakhs) \\
\hline Barrage Construction & 288 \\
Pump Expenditures & 21 \\
Raising Main Expenditure & 157 \\
Pump Houses & 42 \\
Delivery Chamber Charges & 17 \\
Delivery Pipe Charges & 280 \\
Electrical Charges & 70 \\
Miscellaneous & 25 \\
Operating Costs: Annual cost at 3\% of overall initial costs & 27 \\
\hline
\end{tabular}

For the current agricultural yields and water use, household surveys were given to a significant percentage of the population in the study area. Finally, total available water for extraction, storage and distribution was retrieved and estimated from the data given 
by land cover classification map along with the delineated catchment areas from Chapter 1.

\subsubsection{Household Surveys}

Utilizing the village and town wise primary census of India (2011), we observed the study area to have approximately 1000 households. Of this population, we conducted surveys of 200 individual farming households to retrieve responses from $20 \%$ of the population. We followed a stratified random sampling method in which we strived to survey between $20-30 \%$ of households in each of the ten benefitting villages. Table 3-4 shows the breakdown of collected surveys, however we found that the village of Dasanagadde was outside of the area where benefits were predicted, and thus surveys for this village were cancelled and the survey time utilized in the other nine villages.

Table 3-4. Breakdown of surveys collected from the study area based on 2011 census of India

\begin{tabular}{cccc}
\hline Village Name & $\begin{array}{c}\text { Total Households } \\
(2011 \text { Census })\end{array}$ & Number (\#) & Percentage (\%) \\
\hline Agasal & 126 & 38 & 30 \\
Arsapur & 19 & 8 & 42 \\
Belale & 81 & 18 & 22 \\
Bhairumbe & 99 & 20 & 20 \\
Bommanalli & 110 & 25 & 23 \\
Dasanagadde & 27 & 2 & 7 \\
Golikoppa & 16 & 7 & 27 \\
Hulgol & 144 & 39 & 43
\end{tabular}


Malenalli

Sadashivalli
42

305
9

34

200
21

11

Total

969

20

Source: Government of Karnataka, Village boundary shapefile retrieved from bhuvan.nrsc.gov.in

The survey collected socioeconomic attributes such as household, irrigation, agricultural water use, educational level, land holdings, water use for different crops, extent of water scarcity, and resulting loss of crops in recent years. The survey also gathered information on the farmers' perceptions of the status of available water resources in the area, the proposed lift irrigation project, potential use of such projects, and the likely impacts of increased water availability on future cropping patterns.

\subsubsection{Market and Water Use Data}

Market reports for crops found in the study area were retrieved from the Department of Agricultural Marketing and Karnataka State Agricultural Marketing Board. The relevant crops included areca nut, banana, black pepper, rice paddy, and coconut. Sugarcane and dairy were estimated based off average revenue collected from the household surveys. These market values were used to calculate the total market value with total production in quintals per survey individual with the following equation.

$$
R_{c}=P_{c} * Q_{c}
$$

Where $R_{c}$ is the total market value of a specific crop and is computed by multiplying market value of the crop $\left(P_{c}\right)$ by total production (quintals) of the crop per individual $\left(Q_{c}\right)$ for the year of 2017. The gross revenue for each respondent was then calculated by summing the total market value of each crop. 
Furthermore, a portion of the household survey was formulated to collect individual water use for agricultural purposes. Respondents were asked a series of questions on their quantity of mechanical pump systems, along with information such as the main use, horsepower, average hours of use per week, and the number of months of use per year. The total annual extraction of water in liters per household was then derived from this information. Finally, each respondent's area of cropland in acres was acquired.

\subsubsection{Elasticity}

The three variables, gross revenue in Rs. cropland in acres, and annual water extraction in liters, were then run through a regression analysis. The regression analysis is a technique in statistical modeling that estimates relationships between a set of variables. For our analysis, our dependent variable was gross revenue defined as G, as it is the main factor that will be influenced by changes in the independent variables. Our independent variables included the annual water extraction, defined as $\mathrm{W}$, and the land acreage, defined as A.

For this research, the goal was to measure the elasticity of water resources, or the measure of a gross agricultural revenue sensitivity to a change in water resource quantity. Elasticity was calculated using the log-linear regression model, which is defined as,

$$
\ln G=\propto+\beta_{1} \ln W_{1}+\beta_{2} \ln A_{2}
$$

Where $\beta$ represents a one-unit increase of $W_{1}$ or $A_{2}$ that will result in an expected increase in $\ln G$ of $\beta$ units, while $\propto$ represents the constant. 
The log linear regression analysis was run through data analysis tools in Microsoft Excel both with and without the intercept to obtain the minimum and maximum coefficients for water elasticity, which were then averaged to calculate the value used for the baseline analysis.

\subsubsection{Command Area Delineation}

The actual increase in the available water due to the proposed project depends on a variety of factors such as natural availability of river water, regulatory restrictions on extraction and storage, institutional norms on the allocation of water to individual irrigation tanks, etc. Currently, no such rules or norms are made since the project is still going through the budgetary approval process. Assumptions were made following Goel \& Kumar (2004) to compute the volume of water to be stored by multiplying the size of the tank catchment areas by the estimated runoff value of the study area that was calculated in Chapter 1. The ratio was calculated between the full study area acreage and the watershed acreage of the ten tanks along with the annual runoff $(\mathrm{mm})$ to estimate for the annual runoff of the relevant portion of the study area. The relevant watershed covers $7 \%$ of the total runoff in the study area.

Furthermore, we utilized the catchment areas of the ten irrigation tank beneficiaries to delineate the current acreage of different crops to calculate for incremental yield potential between pre and post irrigation project. The individual tanks under the lift irrigation area and their respective acreage, were multiplied by the overall accuracy $(85.11 \%)$ as well as the average per acre and average price that was derived from the overall household survey results. Table 3-5 shows the average price and average per acre yield for the relevant crops. Average price and average per acre yield were not 
collected for sugarcane and dairy during the survey process, and as a result, were estimated using the 5\% of the gross revenue sum of all crops found in Table 3-5.

Table 3-5. Acreage, average price and average per acre yield of crop types found in the command area of ten project tanks

\begin{tabular}{cccc}
\hline Crop Type & Acreage & $\begin{array}{c}\text { Average Price } \\
\text { (Rs. per Quintal) }\end{array}$ & $\begin{array}{c}\text { Average Per Acre } \\
\text { Yield (Quintal) }\end{array}$ \\
\hline Areca Nut & 120.80 & $22,868.21$ & 12.23 \\
Banana & $*$ & $1,088.75$ & 8 \\
Black Pepper & $*$ & $51,087.50$ & 1 \\
Coconut (In Orchard) & $*$ & $2,500.00$ & 4.3 \\
Coconut (Out of Orchard) & 77.90 & $2,500.00$ & 24.09 \\
Rice Paddy & 6.52 & $1,500.00$ & 11.44 \\
\hline
\end{tabular}

*Falls within Areca Nut orchard acreage

\subsubsection{Water Elasticity of Gross Agricultural Revenue}

After running log linear regression for the three variables with intercept, without intercept, and the average of the two, the output values were then input into the Cobb Douglas production function formula with three different scenarios of increased irrigation water resources. This production function represents the relationship between the water elasticity coefficients and the increased irrigation water inputs and their impact on revenue. Three scenarios were chosen for increased irrigation water: (1) $50 \%$ increase from baseline, (2) 100\% increase from baseline, and (3) 150\% increase from baseline. The total annual runoff for the watershed of ten tanks was calculated to be $7,112,809 \mathrm{~m}^{3}$, 
while the current annual water applied for irrigation adjusted for the land in the ten-tank command area was a baseline of $1,727,179 \mathrm{~m}^{3}$. We decided on the three water increase scenarios as they all fall under the total annual runoff while simultaneously conserving more than $50 \%$ of leftover water resources for runoff.

After deciding the water increase scenarios and calculating the water elasticity of gross agricultural revenue, the variables were input into the Cobbs Douglas production function. The resulting output is the gross revenue change in response to a given change in irrigation water use.

Finally, we extracted the net profits from the gross agricultural revenue baseline value to calculate for the incremental benefits. Table 3-6 shows the economics of relevant crops with irrigation in Karnataka that has been modified from Patil et al. (2016). We estimated for $45 \%$ profit by choosing Areca nut orchard net returns to represent annual incremental benefit.

Table 3-6. Economics of relevant crops in the Bhairumbe/Taragod Panchayats, adapted from Patil et al. (2016)

\begin{tabular}{ccc}
\hline Crop & $\begin{array}{c}\text { Gross returns } \\
\text { (Rs.) }\end{array}$ & $\begin{array}{c}\text { Net returns } \\
\text { including water } \\
\text { cost (\%) }\end{array}$ \\
\hline Areca Nut & 114,824 & 45 \\
Coconut & 36,502 & 9 \\
Banana & 114,531 & 17 \\
\hline
\end{tabular}

\subsubsection{Benefit Cost Analysis/Net Present Value}

The economic viability of the project was assessed using the two most popular financial measures of capital investment: benefit-cost ratio (BC ratio) and net present 
value (NPV). The $\mathrm{BC}$ ratio measures the total amount of incremental dollar return on every dollar invested, in current dollar terms, during the life of the project. Whereas the NPV measures the different between total incremental return and total costs, both in present dollar value. For the project to be viable under any of the eleven scenarios being measured, the $\mathrm{BC}$ ratio must be greater than or equal to one, and the NPV must be greater than or equal to zero. For both measures, the future benefits and costs are discounted to present values using the standard social discount rate of $5 \%$ for one scenario, and $10 \%$ for another (Field \& Field 2016).

The lift irrigation project in the study area has been assumed to result in an annual incremental benefit of $B_{t}$ in period $t=1,2 \ldots \mathrm{T}$. The initial costs of the irrigation project are $\mathrm{C}_{0}$ and the annual maintenance and operational costs are $\mathrm{C}_{\mathrm{t}}$. We assumed that the economic life of the proposed project will be $\mathrm{T}=50$ years, so the $\mathrm{BC}$ ratio and NPV of the project is calculated as,

$$
\begin{gathered}
\text { BC Ratio }=\sum_{t=1}^{50} \frac{B_{t}}{(1+r)^{t}} / \sum_{t=0}^{50} \frac{C_{t}}{(1+r)^{t}} \\
\mathrm{NPV}=\sum_{t=1}^{50} \frac{B_{t}}{(1+r)^{t}}-\sum_{t=0}^{50} \frac{C_{t}}{(1+r)^{t}}
\end{gathered}
$$

Where $t$ represents time and $r$ represents the $5 \%$ discount rate or rate of return from a risk-free financial investment.

For benefits, the baseline profit value from the Cobbs Douglas production function was input as the incremental benefits along with increased potential labor income at an annual $45 \%$ of the profit value. We considered the incremental agriculture 
and labor benefits to begin at year 4 after initial construction. For costs, the initial construction costs were divided into the first three years and then operating costs were estimated as $3 \%$ of the total initial construction costs for years 4 through 50 .

For other scenarios, added costs and benefits were introduced in the form of bena land conversion. Bena land is defined as grassland near rice paddy plots that is owned and managed for fodder by rural farmers. We asked in the household survey if, with increased irrigation potential, farmers would establish crops on the bena land. The survey revealed that $82.14 \%$ of farmers would be willing to convert, resulting in scenarios with an introduction of cost of crop establishment/maintenance and added labor income. These various scenarios were calculated to measure the viability of the lift irrigation project for the rural farming community in the ten-tank command areas that fall within the Bhairumbe/Taragod Panchayats.

In the scenarios of bena land conversion, we established estimates for benefits and costs based on pre-existing market data and initial cost of crops. The initial cost of bena land to crop land conversion included land preparation, planting, and establishment of onfarm irrigation. The maintenance costs and annual interest rates stayed consistent from years 4 through 11 . From years 12 onwards, the maintenance was estimated to be Rs. 50,000 or $55 \%$ of the gross revenue if the value was larger than the default Rs. 50,000 . Benefits were constructed in the form of additions to revenue along with incremental labor income at $20 \%$ of the gross revenue of the converted bena land. The gross revenue of this land was calculated using the average revenue of areca nut and coconut, as these are the leading cash crops and would be the crops chosen to establish on the converted land. The gross revenue of converted bena land would gradually increase from years 12 
to 19 when annual interest was being paid off, and then benefits would stay constant from year 20 onwards.

\subsection{RESULTS \& DISCUSSION}

The 200 household surveys received land and water data from farmers that covered over 2,500 acres of cropland with 540 individual cattle identified. Figure 3-1 shows the breakdown of agriculture categories gathered from the survey. Of the 200 respondents, 174 had areca nut, 150 had dairy animals, 56 had rice paddy, and 12 had sugarcane. Furthermore, a total of approximately 170,000 liters of water is consumed per day for all respondents for both household and agricultural use, with an average individual household use of 954 liters. The main source of this water is through captured rainfall, in which $78 \%$ of the respondents are dependent on.

Figure 3-1. Ownership breakdown of agricultural commodities


Questions on water scarcity found that $67 \%$ of respondents stated that the current water availability is insufficient to reach their household/agricultural needs, with the highest record of insufficient water resources in 2017. The majority of the respondents 
attributed the water scarcity impacts to decline in natural vegetation as well as rainfall during both the pre- and post-monsoon season. This scarcity has led to detrimental impacts on farmland, with $60 \%$ of respondents suffering from greater than $30 \%$ loss of crop yields in 2017.

Additionally, data was collected on how farmers are dealing with the water shortage with investments into alternative sources of irrigation. Currently, $45 \%$ of the respondents utilized either drip or sprinkler irrigation for their areca nut orchard, with $80 \%$ of the remaining respondents interested in irrigation infrastructure but do not have the necessary funds. The respondents are dependent on rainfall not only for sheet flow, but also to recharge the groundwater wells, as $100 \%$ of the respondents used open wells as their primary source of household water. For recent and upcoming investments, $90 \%$ of the bore wells that were constructed in the last five years had failed, and as a result, less than $20 \%$ of respondents expressed interest in personal investments for water resources. The lack of personal funds for improved infrastructure leaves much to be desired from community and governmental interventions.

\subsubsection{Farmers Perceptions of Lift Irrigation Project}

The survey also focused on gathering information on the farmers' perceptions of the proposed irrigation project and the potential benefits that could result. Only $48 \%$ of respondents were aware of the proposed lift irrigation project prior to the survey. This means that there is a need for the agricultural institutions to have a wider reach within the community to spread awareness of modern irrigation schemes. $78 \%$ of the respondents supported the lift irrigation project after a short briefing, and a more informed population could have potential to increase incentives for government investment. 
There were a multitude of benefits that respondents projected to experience in the event of the lift irrigation project. The benefits include cooler climate, healthier environmental conditions, natural forest growth, increase in wildlife population, and higher agricultural yields. However, respondents do have some general concerns with the project to a certain extent. $12 \%$ opposed the project, as they do not have trust in the government to properly allocate funds and believe that the de-siltation and maintenance of the current irrigation tanks should be prioritized.

In the event of the lift irrigation project being discontinued, respondents plan to increase bore wells, groundwater recharge facilities, and rooftop rainwater harvesting structures. Although there is no certainty that the irrigation infrastructure will be successful, and thus more than $45 \%$ of respondents have no personal future investment plans, with $15 \%$ expressing the need to migrate.

\subsubsection{Log-Linear Regression Analysis}

Tables 3-7 and 3-8 show the log transformed output results of the log-linear regression analysis. The underlined coefficient for the independent variable of agricultural water resources for the analysis with the intercept was used as the lowest scenario for the Cobbs Douglas production function, while the underlined coefficient for agricultural water resources without the intercept was used for the highest scenario. These values are 0.16 and 0.81 respectively and were averaged to get the median scenario coefficient of 0.48 .

The p-value for the water resources variable is $7.27 \mathrm{E}-07$ with intercept and $1.38 \mathrm{E}$ 207 without intercept, meaning we reject the null hypothesis and conclude statistical significance of this independent variable. The $t$ statistic is the estimated coefficient 
divided by its standard error, which is 5.12 with intercept and 153.09 without intercept, which is significant at both levels. Finally, adjusted $\mathrm{R}^{2}$ values of $65 \%$ and $99 \%$, respectively, indicating almost all variability of the response data around the mean.

Table 3-7. Summary output of Log-Linear model with intercept

\begin{tabular}{ccccc}
\hline Variable & Coefficient & Std. Error & t-statistic & P-Value \\
\hline Agricultural Water Resources & $\underline{0.16}$ & 0.28 & 5.12 & $7.27 \mathrm{E}-07$ \\
Land Acreage & 0.52 & 0.04 & 12.87 & $6.63 \mathrm{E}-28$ \\
Intercept & 4.54 & 0.03 & 16.12 & $7.53 \mathrm{E}-38$
\end{tabular}

Other Statistics: $\mathrm{R}^{2}=0.65 ; \mathrm{F}=183.17 ;$ Obs $=200$

Table 3-8. Summary output of Log-Linear model without intercept

\begin{tabular}{ccccc}
\hline Variable & Coefficient & Std. Error & t-statistic & P-Value \\
\hline Agricultural Water Resources & $\underline{0.81}$ & 0.005 & 153.09 & $1.38 \mathrm{E}-207$ \\
Land Acreage & 0.10 & 0.062 & 1.66 & 0.09 \\
Intercept & 0 & N/A & N/A & N/A \\
\hline
\end{tabular}

Other Statistics: $\mathrm{R}^{2}=0.99 ; \mathrm{F}=14577.12 ;$ Obs $=200$

After collecting the residual values, heteroscedasticity was measured for, meaning when the changeability of a variable is not equal over a range of values of a succeeding variable that predicts it. Following Koenker \& Bassett Jr. (1982) Figures 3-2 and 3-3 were constructed using scatter plots of the 200 residual values with and without intercepts. If their plots show any kind of pattern of residuals and fitted values, then they would show heteroscedasticity leading to non-constant variance of errors and distortion of findings. However, the figures revealed no discernible pattern and thus express that the regression output has constant variance across the fitted values. 
Figure 3-2. Homoscedacity of Log-Linear model with intercept

Homoscedasticity for Log-Linear Model with Intercept

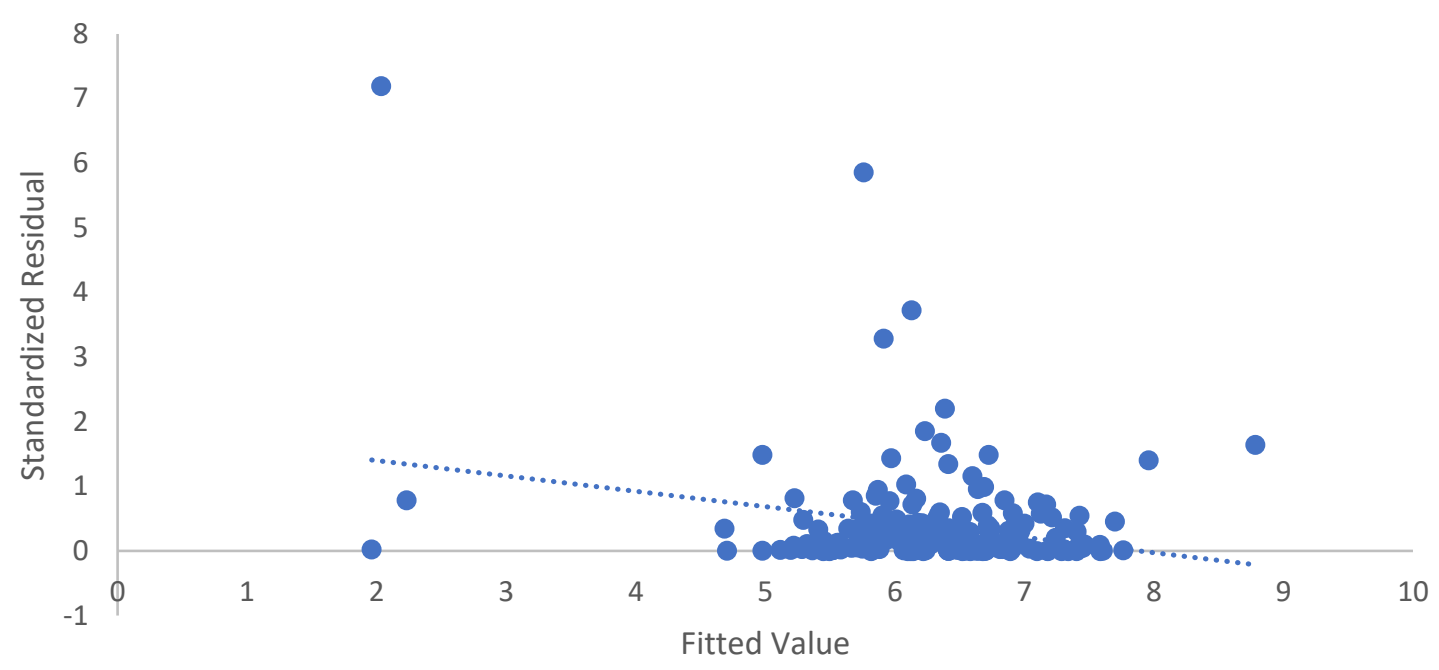

Figure 3-3. Homoscedasticity of Log-Linear model without intercept

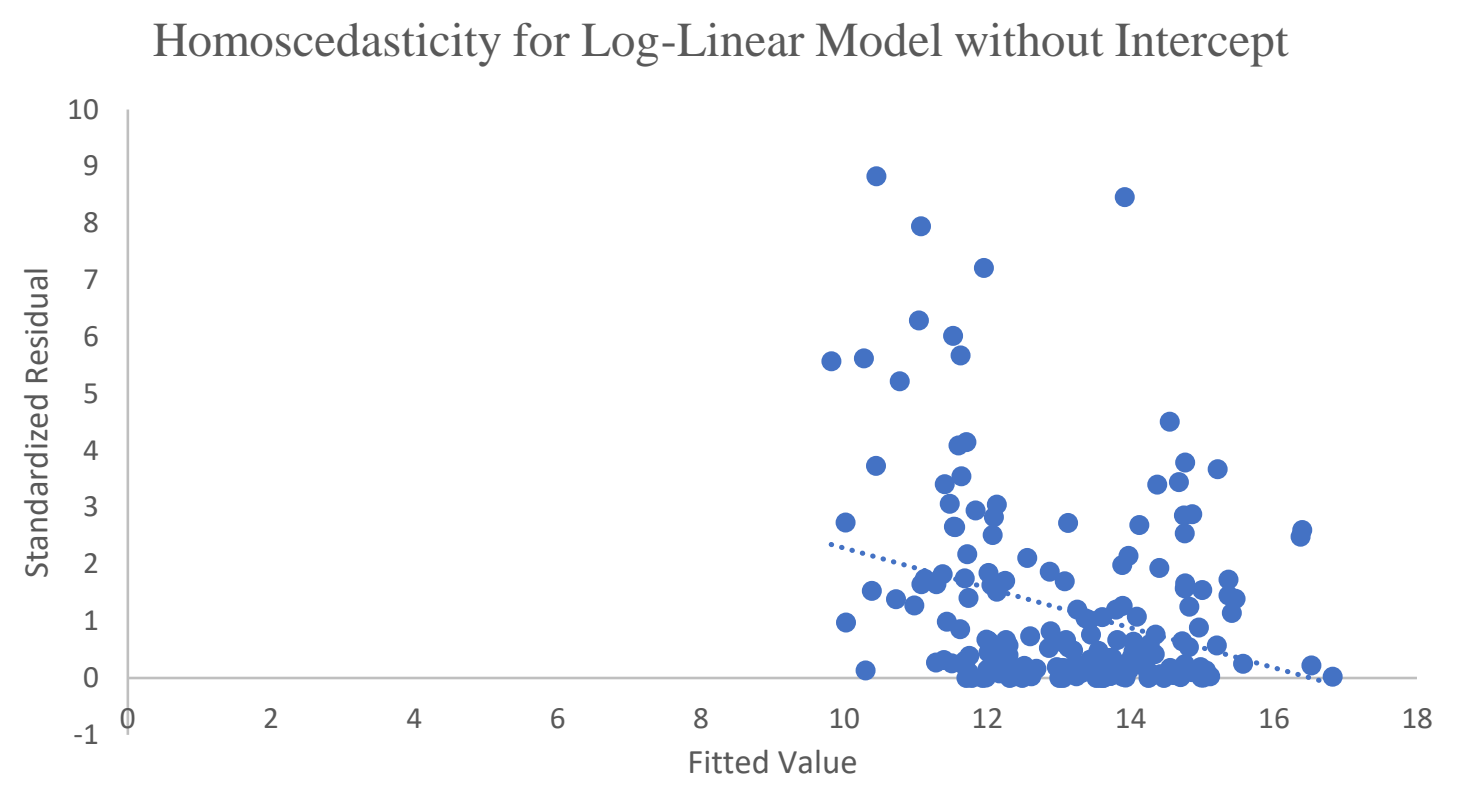

\subsubsection{Water Resources, Gross Revenue, and Net Profit Benefits}

After the coefficients for water elasticity (i.e. 0.16, 0.48, and 0.81) were calculated, the values along with the three scenarios of water increase (i.e. 50\%, 100\%, and 150\% 
increase from baseline) were input into equation 3-3 to output the effect on gross agricultural revenue from baseline. The ten-tank baseline annual water currently applied was $1,727,179 \mathrm{~m}^{3}$ and the ten-tank baseline gross agricultural revenue was Rs. 49,500,580. Table 3-9 gives measurements of the nine gross revenue results in rupees provided through the variety of variables integrated in the Cobbs Douglas production function equation (equation 3-3). This gross revenue exhibits the overall revenue margin increase at different levels of water elasticity and percent increase of water.

Table 3-9. Scenarios of gross revenue increase with water elasticity and water increase variables

\begin{tabular}{cccc}
\hline Gross Revenue (Rs.) & \multicolumn{3}{c}{ Water Elasticity of Gross Agricultural Revenue } \\
\hline & 0.16 & 0.48 & 0.81 \\
\hline Water Increase Scenario & & & \\
\cline { 1 - 2 } $50 \%$ Increase & $3,960,046$ & $11,880,139$ & $20,047,735$ \\
& & & \\
$100 \%$ Increase & $7,920,092$ & $23,760,278$ & $40,095,470$ \\
& & & \\
$150 \%$ Increase & $11,880,139$ & $35,640,418$ & $60,143,205$ \\
\hline
\end{tabular}

After collection of gross revenue scenarios, the net profits were calculated as $45 \%$ of overall revenue (Patil et al. 2016) for each of the nine scenarios in Table 3-10, as these values will be the final incremental benefits that were implemented into the $\mathrm{BC}$ ratio and NPV formulas (equations 3-4 and 3-5). These benefits were estimated to begin in the fourth year after the first three years of initial construction of the project. The scenario of 0.48 water elasticity and $100 \%$ increase in water resources was used as the baseline for the BC and NPV analyses as it is the midpoint of revenue. 
Table 3-10. Scenarios of net profits with water elasticity and water increase variables, based off $45 \%$ of agricultural revenue (Patil et al. 2016)

\begin{tabular}{cccc}
\hline Net Profits (Rs.) & \multicolumn{3}{c}{ Water Elasticity of Gross Agricultural Revenue } \\
\hline Water Increase Scenario & 0.16 & 0.48 & 0.81 \\
\hline $50 \%$ Increase & $1,782,020$ & $5,346,062$ & $9,021,480$ \\
& & & \\
$100 \%$ Increase & $3,564,041$ & $10,692,125^{*}$ & $18,042,961$ \\
& & & \\
$150 \%$ Increase & $5,346,062$ & $16,038,188$ & $27,064,442$ \\
\hline
\end{tabular}

*Baseline value for incremental benefit analysis

Table 3-11 takes the gross revenue from Table 3-9 to further calculate for labor income in the nine scenarios. Labor income is considered a benefit as the introduction of higher yields through water increase will allow for increased potential for labor wages in the community. Utilizing the economics of rural agriculture from Patil et al. (2016), the labor income values were estimated to be $20 \%$ of overall gross revenue. The incremental labor income benefits were assumed to begin in the fourth year of the 50-year project along with incremental benefits to net profits.

Table 3-11. Scenarios of gross revenue with water elasticity and water increase variables, based off $20 \%$ of agricultural revenue (Patil et al. 2016)

\begin{tabular}{cccc}
\hline Labor Income (Rs.) & \multicolumn{4}{c}{ Water Elasticity of Gross Agricultural Revenue } \\
\hline & 0.16 & 0.48 & 0.81 \\
\hline Water Increase Scenario & & & \\
\cline { 1 - 3 } $50 \%$ Increase & 792,009 & $2,376,028$ & $4,009,547$
\end{tabular}


$100 \%$ Increase

$150 \%$ Increase
$1,584,019$

$2,376,028$
$4,752,056$

$8,019,094$

$7,128,084$
$12,028,641$

\subsubsection{Viability of Lift Irrigation Project Scenarios}

The cumulative costs and benefits of the lift irrigation projects were finally integrated into the 50-year construction and management plan. The first year of the project included solely the construction of the barrage, with construction of pump expenditures, raising of the main expenditure, pump houses, delivery chambers, delivery pipe charges, electrical charges, and miscellaneous costs being distributed in years two and three. The fourth year onwards included the cost of maintenance and operation at 3\% of the initial construction costs. Alternatively, the incremental benefits began after initial construction in year four.

The project benefits are largely dependent on the type of crops grown in the command area. The ten-tank project command area has one of the best areca nut and pepper production yields in the entire Uttara Kannada district. Most of the cropland in this command area is under the above two high value crops. Based on our primary survey and discussion with stakeholders, if more water becomes available, farmers will likely expand their cropland eventually. Utilizing this data, eleven different scenarios were constructed to calculate for BC ratio and NPV. These scenarios are present in Table 3-12 at a 5\% discount rate and Table $3-13$ at a $10 \%$ discount rate and express the viability of the lift irrigation project for a set of different projected factors. For the baseline net profits of Rs. 10,692,125, the conversion of bena land to areca nut orchard (including 
coconut) was integrated into the analysis for Medium Income Increase-100\% Water Increase. This scenario included the total bena land retrieved from the household survey at 82.14 acres, multiplied by the $82 \%$ of respondents who conveyed interest in making the conversion to get 67.36 acres. To calculate for gross revenue, the per acre revenue for coconut and areca nut were averaged together, as these would be the crops that respondents would establish on the bena land. This average value of Rs. 169,906 was then multiplied by the 67.36 acres to get the potential gross revenue for converted lands.

Furthermore, cost of establishment, maintenance, and annual interest on loans for the introduced cropland were also incurred for Medium Income Increase-100\% Water Increase. We also added a more conservative calculation by taking $50 \%$ of the 82.14 acres and running through the same analysis with lower costs and benefits due to less land being converted for agriculture. The third scenario for Medium Income Increase$100 \%$ Water Increase utilized the baseline water elasticity and percent water increase for a $0 \%$ change in bena land conversion and thus only cost of irrigation construction/maintenance and benefits of net profits/labor income from preexisting agriculture. The remaining scenarios utilized the different combinations of water elasticity and percent water increase found in Tables 3-10 and 3-11 for projected net profits and labor income benefits, not including the bena land variables.

The NPV's were positive and the BC ratios were above 1 in seven out of the eleven scenarios that were studied. While viable, the scenarios with conversion to bena land don't significantly increase the NPV and BC ratio due to the increase costs experienced by the farmer. Naturally, the scenarios with a higher water elasticity and high percent water increase showed high viability for return of investment in the ten-tank 
command area, and we recommend that the lift irrigation project be implemented if it reaches the capacity of any of the seven estimated scenarios that received a $\mathrm{BC}$ ratio $>1$.

Furthermore, with the addition of a higher discount rate at $10 \%$, we still found the viability to be the same for all scenarios. This allows for the deduction that analysis is robust, and the project shows viability under a variety of rates of return.

Table 3-12. Net Present Values and Benefit-Cost Ratios for the proposed lift irrigation project at 5\% Discount Rate

\begin{tabular}{|c|c|c|c|}
\hline \multirow[b]{2}{*}{ Water Increase Scenario } & \multicolumn{3}{|c|}{$\begin{array}{l}\text { Increase in Agriculture Income Scenario } \\
\text { (Percent Increase in Income for a Percent } \\
\text { Increase in Water Availability) }\end{array}$} \\
\hline & $\begin{array}{c}\text { Low } \\
(0.16 \%)\end{array}$ & $\begin{array}{c}\text { Medium } \\
(0.48 \%)\end{array}$ & $\begin{array}{c}\text { High } \\
(0.81 \%)\end{array}$ \\
\hline & \multicolumn{3}{|c|}{ Benefit-Cost Ratio } \\
\hline $50 \%$ Increase & 0.32 & 0.97 & 1.64 \\
\hline $100 \%$ Increase - no cropland expansion & 0.65 & $1.95^{\mathrm{a}}$ & 3.28 \\
\hline $100 \%$ Increase $-50 \%$ bena land conversion & -- & $1.64^{\mathrm{a}}$ & -- \\
\hline $100 \%$ Increase $-82 \%$ bena land conversion & -- & 1.58 & -- \\
\hline \multirow[t]{2}{*}{$150 \%$ Increase } & 0.97 & 2.92 & 4.93 \\
\hline & \multicolumn{3}{|c|}{ Net Present Values (Rs. Millions) } \\
\hline $50 \%$ Increase & -83 & -3 & 79 \\
\hline $100 \%$ Increase - no cropland expansion & -43 & $117^{\mathrm{a}}$ & 282 \\
\hline $100 \%$ Increase $-50 \%$ bena land conversion & -- & $131^{\mathrm{a}}$ & -- \\
\hline $100 \%$ Increase $-82 \%$ bena land conversion & -- & 149 & -- \\
\hline $150 \%$ Increase & -3 & 237 & 484 \\
\hline \multicolumn{4}{|c|}{$\begin{array}{l}\text { The two most likely scenarios } \\
\text { Table 3-13. Net Present Values and Benefit-Cost Ratios for the proposed lift irrigation } \\
\text { project at } 10 \% \text { Discount Rate }\end{array}$} \\
\hline & \multicolumn{3}{|c|}{$\begin{array}{l}\text { Increase in Agriculture Income Scenario } \\
\text { (Percent Increase in Income for a Percent } \\
\text { Increase in Water Availability) }\end{array}$} \\
\hline Water Increase Scenario & $\begin{array}{c}\text { Low } \\
(0.16 \%)\end{array}$ & $\begin{array}{c}\text { Medium } \\
(0.48 \%)\end{array}$ & $\begin{array}{c}\text { High } \\
(0.81 \%)\end{array}$ \\
\hline
\end{tabular}




\begin{tabular}{lccc} 
50\% Increase & 0.20 & 0.61 & 1.03 \\
100\% Increase - no cropland expansion & 0.41 & $\mathbf{1 . 2 2}^{\mathbf{a}}$ & 2.06 \\
100\% Increase - 50\% bena land conversion & -- & $\mathbf{1 . 0 7}^{\mathbf{a}}$ & -- \\
100\% Increase - 82\% bena land conversion & -- & 1.04 & -- \\
150\% Increase & 0.61 & 1.83 & 3.09 \\
& & & \\
& Net Present & Values (Rs. Millions) \\
50\% Increase & -75 & -37 & 3 \\
$100 \%$ Increase - no cropland expansion & -56 & $\mathbf{2 1}^{\mathbf{a}}$ & 100 \\
100\% Increase - 50\% bena land conversion & -- & $\mathbf{1 0}^{\mathbf{a}}$ & -- \\
$100 \%$ Increase - 82\% bena land conversion & -- & 7 & -- \\
$150 \%$ Increase & -37 & 78 & 196 \\
\hline $\mathbf{a}$
\end{tabular}

a The two most likely scenarios

In both discount rate circumstances, we believe that of the eleven scenarios, the two most likely scenarios would be Medium Income Increase-100\% Water Increase without and with $50 \%$ bena conversion. In Table 3-12, the BC ratios for these two scenarios are 1.95 and 1.64, respectively. The NPV's are Rs. 117 million and Rs. 131 million, respectively, over the 50-year life of the project. In Table 3-13, the BC ratios for these two scenarios are 1.22 and 1.07, respectively. The NPV's are Rs. 21 million and Rs. 10 million. Therefore, we conclude that the proposed lift irrigation project will be economically viable even under conservative economic and hydrological scenarios. We also note that the above results were made even without considering other tangible and non-tangible benefits of the project.

\subsection{CONCLUSION}

LIS have the potential to improve irrigation in drought-induced areas and augment the agricultural income of rural farming communities. In the 
Bhairumbe/Taragod Panchayats, there was motivation from the respondents of the household survey to continue to rally for large and small-scale irrigation infrastructure and management. Based on the cost-benefit analysis of agriculture and water resources, it can be concluded that if expected potential full benefits exist for the proposed lift irrigation project, then it will yield substantial economic returns in the 50-year project plan.

This analysis allows for a scientific framework that can be utilized when deciding on the viability of a watershed project that brings costs and benefits. However, impacts on the agricultural sector are the easiest to quantify, whereas this study did not attempt to assess the resulting cost/benefits on common lands (Ninan \& Lakshmikanthamma 2001). Further studies on watershed management projects could follow-up with additional variables for both economic viability, social desirability, and ecological improvement in the dry regions of India.

\subsection{REFERENCES}

Ackermann, Richard (2012) 'New Directions for Water Management in Indian Agriculture', Global Journal of Emerging Market Economies, 4(2): 227-88.

Agoramoorthy, G. \& Huse, M.J. (2008) 'Reviving India’s Grassroots Social Work for Sustainable Develop- ment', International Social Work 51: 544-55.

Agoramoorthy, G., \& Hsu, M. J. (2015). Irrigation-based social work relieves poverty in India's drylands. International Social Work, 58(1), 23-31. https://doi.org/10.1177/0020872812463106

Agoramoorthy, G., Chaudhary, S., \& Hsu, M. J. (2009). Sustainable development using small dams an approach to avert social conflict and relive poverty in india's semiarid regions. Asian Pacific Journal of Social Work, 19(2), 52-69. https://doi.org/10.1080/21650993.2009.9756063 
Amarasinghe, U.A., Shah, T., Turral, H., Anand, B.K., 2007. India's Water Future for 2025-2050: Business-as-usual Scenario and Deviations. International Water Management Institute, Colombo, Sri Lanka Available at:. http://www.iwmi.cgiar. org/Publications/IWMI_Research_Reports/PDF/PUB123/RR123.pdf

AQUASTAT, 2010.Water Resources Development and Management Service. Food and Agriculture Organization of the United Nations, Rome, Italy Available at:. http://www. fao.org/nr/water/aquastat/main/index.stm

Ashra, Sunil \& Chakravarty, Malini (2007) 'Input Subsidies to Agriculture: Case of Subsidies to Fertiliser Industry across Countries', Vision: The Journal of Business Perspective, 11(3): 35-58.

Barker, R., \& Molle, F. (2004). Evolution of irrigation in South and Southeast Asia. Comprehensive Assessment Secretariat. Comprehen- sive Assessment Research Report 5, International Water Management Institute, Colombo, Sri Lanka.

Biswas, A. K., \& Hartley, K. (2017). From evidence to policy in India's groundwater crisis. In the Diplomat.

Briscoe, J. (1996). Water as an economic good: The idea and what it means in practice. Paper presented at the 16th world congress on irrigation and drainage, Cairo, September 15-22, 1996.

Burt, C., and Styles, S. (1999) Modern Water Control and Management Practices in Irrigation: Impact on Performance. In Modernization of Irrigation System Operations, edited by D. Renault. Proceedings of the Fifth International IT IS Network Meeting, Aurangabad, India, 28-30 October 1998. Bangkok: Food and Agriculture Organization, RAP Publication 99/43, 93-114.

Chambers, R. (1974). The Organisation and Operation of Irrigation: An Analysis of Evidence from South India and Sri Lanka. Seminar St(9-16), 1-19.

Chindarkar, N., \& Grafton, R. Q. (2019). India's depleting groundwater: When science meets policy. Asia and the Pacific Policy Studies, 6(1), 108-124. https://doi.org/10.1002/app5.269

Choudhury, N. (2007). Irrigation service delivery in canal systems: A study of eight canal systems in India. International Journal of Rural Management, 3(1), 127-148. https://doi.org/10.1177/097300520700300106

Choudhury, Nirmalya (2007) 'Irrigation Service Delivery in Canal Systems: A Study of Eight Canal Systems in India', International Journal of Rural Management, 3(1): $127-48$. 
Choudhury, Nirmalya, Banerjee, Parthosarathy \& Roy, Dayabati (2009) 'Panchayat Irrigation Management: A Case Study of Institutional Reforms Programme over Teesta Command in West Bengal', International Journal of Rural Management, 5(1): 1-20.

Field, B., \& Field, M. (2016). Environmental Economics: An Introduction. In Urban and Environmental Economics: An Introduction. https://doi.org/10.4324/9780203825990

Goel, A. K., \& Kumar, R. (2005). Economic analysis of water harvesting in a mountainous watershed in India. Agricultural Water Management, 71(3), 257266. https://doi.org/10.1016/j.agwat.2004.09.00

Gupta, Susmita (2011) “"Paschim Banga Kheria Sabar Kalyan Samiti”, Puruliya, West Bengal, India: Case Study of an NGO's Role in Poverty Alleviation', International Journal of Rural Management, 7(1-2): 149-58.

Holman, I., Allen, D., Cuthbert, M., Goderniaux, P., 2012. Towards best practice for assessing the impacts of climate change on groundwater. Hydrogeol. J. 20 (1):14. https://doi.org/10.1007/s10040-011-0805-3.

Ioris, A.A.R.; Hunter, C.; Walker, S. The development and application of water management sustainability indicators in Brazil and Scotland. J. Environ. Manag. $2008,88,1190-1201$.

Jha, P. (2002) Land Reforms in India. New Delhi: SAGE.

Kasi, E. (2011) 'Developmental Initiatives and Sericulture in a South Indian Village', South

Kimmich, C. (2013b), 'Linking Action Situations: Coordination, Conflicts, and Evolution in Electricity Provision for Irrigation in Andhra Pradesh, India', Ecological Economics 90, 150-158.

Koenker, R., \& Bassett, G. (1982). Robust Tests for Heteroscedasticity Based on Regression Quantiles. Econometrica, 50(1), 43-61. doi:10.2307/1912528

Linsley, R.K., Franzini, J.B., 1979. Water Resources Engineering. McGraw-Hill, New York.

Loucks, D.P.; Gladwell, J.S. Sustainability Criteria for Water Resource Systems; Cambridge University Press: Cambridge, UK, 1999. 
Meher, Rajkishor (2009) 'Globalization, Displacement and the Livelihood Issues of Tribal and Agriculture Dependent Poor People: The Case of Mineral-based Industries in India', Journal of Developing Societies, 25(4): 457-80.

Molden, D. (2007), Water for Food, Water for Life. A Comprehensive Assessment of Water Management in Agriculture, Earthscan Publishing House, London, Sterling, VA.

Mudrakartha, Srinivas, Rathire, M.S. \& Sudhanshu (2011) 'Adaptation, Groundwater Recharge and Livelihood Enhancement: Experiences from Saurashtra Groundwater Recharging Movement', International Journal of Rural Management, 7(1-2): 43-82.

Mukherji, A; Facon, T.; Burke, J.; de Fraiture, C.; Faures, J. M.; Fuleki, B; Giordano, M.; Molden, D; Shah, T.. (2009) Revitalizing Asia's irrigation: to sustainably meet tomorrow's food needs. Colombo, Sri Lanka: International Water Management Institute (IWMI); Rome, Italy: FAO. 39p.

Narayanamoorthy, A. (2004). Drip irrigation in India: Can it solve water scarcity? Water Policy, 6, 117-130. https://doi.org/10.2166/wp.2004.0008

National Sample Survey Organization (NSSO) (2005). Situation assessment survey of farmers: Some aspects of farming. 59th Round, January-December 2003, Report 496(59/33/3). Department of Statis- tics, Government of India, New Delhi.

National Water Policy. 2002. Ministry of Water Resources, Government of India.

Nawalawala, B.N., 1994. Water resource development and water conservation strategy in India. In: Proceedings of the 17th ICID European Regional Conference on Irrigation and Drainage, Varna, Bulgaria, May 16-22, pp. 69-78.

Ninan, K. N., \& Lakshmikanthamma, S. (2001). Social Cost-benefit Analysis of a Watershed Development Project in Karnataka, India. AMBIO: A Journal of the Human Environment, 30(3), 157-161. https://doi.org/10.1579/0044-7447-30.3.157

Patil Kumar, K., Chandrakanth, M. G., Sadhana, H. S., \& Olekar, J. (2016). Returns to Irrigation, Natural Resource Management, Research and Extension. In ReVisiting Agricultural Policies in the Light of Globalisation (pp. 81-94).

Reddy, V.R. (2003) 'Irrigation: Development and Reforms', Economic and Political Weekly, 38(12-13): 1179-89.

Robert Chambers. (1982). Irrigation Management: Ends, Means and Opportunities. (Giri Institute of Development Studies), 1-32. 
Scott, C.A., 2013. Electricity for groundwater use: constraints and opportunities for adaptive response to climate change. Environ. Res. Lett. 8 (3), 035005.

Shah, T. (2014). Groundwater governance and irrigated agriculture. In Global Water Partnership Technical Committee (TEC) Background Paper No.19. Stockholm, Sweden: Global Water Partnership.

Shah, T., Singh, O. P., \& Mukherji, A. (2006). Some aspects of South Asia's groundwater irrigation economy: Analyses from a survey in India, Pakistan, Nepal terai and Bangladesh. Hydrogeology Journal, 14(3), 286-309.

Shah, T., Ul Hassan, M., Khattak, M. Z., Banerjee, P. S., Singh, O. P., \& Rehman, S. U. (2009). Is Irrigation Water Free? A Reality Check in the Indo-Gangetic Basin. World Development, 37(2), 422-434. https://doi.org/10.1016/j.worlddev.2008.05.008

Sishodia, R. P., Shukla, S., Wani, S. P., Graham, W. D., \& Jones, J. W. (2018). Future irrigation expansion outweighs groundwater recharge gains from climate change in semi-arid India. Science of the Total Environment, 635, 725-740. https://doi.org/10.1016/j.scitotenv.2018.04.130

Srivastava, D., Rao, K.V.G.K., Visvanatha, N.A., 2000. Planning and management of integrated water and agricultural management. Role of drainage and challenges in 21 st century. In: Proceedings of the Eighth ICID International Drainage Workshop, New Delhi, pp. 307-322.

Swain M., 1998. Water Rate Fixation in Major and Medium Irrigation Projects in Orissa: Issues and Problems. Water and Energy International. 55 (2), 63-72.

Swain, M., \& Das, D. K. (2008). Participatory Irrigation Management in India: Implementations and Gaps. Journal of Developments in Sustainable Agriculture, 3, 28-39. https://doi.org/10.11178/jdsa.3.28

Tiwari, G.N., Goyal, R.K., 1998. Greenhouse Technology: Fundamentals, Design, Modeling and Applications. Narosa Publishing House, New Delhi, p. 503.

Tiwary, Rakesh (2009) 'Tanks, Multiple Uses and Their Political Ecologies in West Bengal', International Journal of Rural Management, 5(1): 21-48.

Tung, Y.K., 1992. Probability distribution for benefit cost ratio and net benefit. J. Water Resour. Planning Manage. 118 (2), 133-150.

Zaveri, E., Grogan, D. S., Fisher-Vanden, K., Frolking, S., Lammers, R. B., Wrenn, D. H., ... Nicholas, R. E. (2016). Invisible water, visible impact: Groundwater use 
and Indian agriculture under climate change. Environmental Research Letters, 11. https://doi.org/10.1088/1748-9326/11/8/084005 
APPENDICES

Daily Rainfall data in the study area from 2009-2017

\begin{tabular}{|c|c|c|c|c|c|c|c|c|c|c|c|c|}
\hline \multicolumn{3}{|c|}{ Annual Rainfall for 2009 (mm) } & \multirow[b]{2}{*}{ March } & \multirow[b]{2}{*}{ April } & \multirow[b]{2}{*}{ May } & \multirow[b]{2}{*}{ June } & \multirow[b]{2}{*}{ July } & \multirow[b]{2}{*}{ August } & \multirow[b]{2}{*}{ September } & \multirow[b]{2}{*}{ October } & \multirow[b]{2}{*}{ November } & \multirow[b]{2}{*}{ December } \\
\hline Day & January & February & & & & & & & & & & \\
\hline 1 & 0 & 0 & 0 & 0 & 0 & 0 & 9.6 & 2 & 3.8 & 21 & 0 & 0 \\
\hline 2 & 0 & 0 & 0 & 0 & 0 & 0 & 23.2 & 0 & 28.2 & 19.8 & 0 & 0 \\
\hline 3 & 0 & 0 & 0 & 0 & 0 & 0 & 84 & 11.8 & 1.8 & 61 & 0 & 0 \\
\hline 4 & 0 & 0 & 0 & 0 & 0 & 0 & 65.8 & 41 & 13.6 & 28.2 & 0 & 0 \\
\hline 5 & 0 & 0 & 0 & 0 & 0 & 0 & 17.6 & 7.8 & 86.4 & 8.4 & 0 & 0 \\
\hline 6 & 0 & 0 & 0 & 0 & 0 & 0 & 51 & 5.8 & 37 & 6.2 & 0 & 0 \\
\hline 7 & 0 & 0 & 0 & 9.8 & 0 & 0 & 44 & 6.2 & 13.2 & 0 & 0 & 0 \\
\hline 8 & 0 & 0 & 0 & 0 & 0 & 0 & 57 & 2.4 & 2 & 0 & 0 & 0 \\
\hline 9 & 0 & 0 & 0 & 0 & 0 & 0 & 78.4 & 3.2 & 0 & 0 & 5.2 & 0 \\
\hline 10 & 0 & 0 & 0 & 0 & 0 & 0 & 57.8 & 2.8 & 5 & 0 & 8.4 & 0 \\
\hline 11 & 0 & 0 & 0 & 0 & 0 & 0 & 44 & 3 & 1.8 & 0 & 13.2 & 0 \\
\hline 12 & 0 & 0 & 0 & 0 & 0 & 0 & 27.2 & 2 & 0 & 0 & 12 & 0 \\
\hline 13 & 0 & 0 & 0 & 0 & 0 & 0 & 8 & 3.2 & 0 & 32.8 & 0 & 0 \\
\hline 14 & 0 & 0 & 0 & 0 & 0 & 0 & 44.6 & 0 & 0 & 0 & 3.6 & 0 \\
\hline 15 & 0 & 0 & 0 & 0 & 0 & 0 & 82 & 2.6 & 3.2 & 6.2 & 0 & 0 \\
\hline 16 & 0 & 0 & 0 & 0 & 0 & 0 & 87.2 & 3.2 & 1.4 & 0 & 7.8 & 0 \\
\hline 17 & 0 & 0 & 0 & 0 & 0 & 23.2 & $\begin{array}{l}48.2 \\
\end{array}$ & 5 & 0 & 0 & 11.6 & 0 \\
\hline 18 & 0 & 0 & 0 & 0 & 0 & 6.4 & 80.6 & 7.6 & 0 & 0 & 0 & 0 \\
\hline 19 & 0 & 0 & 0 & 0 & 0 & 0 & 20.2 & 0 & 0 & 0 & 12.4 & 0 \\
\hline 20 & 0 & 0 & 9.4 & 0 & 0 & 10.2 & 24.8 & 2 & 0 & 0 & 0 & 0 \\
\hline 21 & 0 & 0 & 0 & 0 & 0 & 0 & 12.4 & 0 & 38.4 & 0 & 0 & 0 \\
\hline 22 & 0 & 0 & 0 & 0 & 0 & 0 & 32 & 1.8 & 14.8 & 0 & 0 & 0 \\
\hline 23 & 0 & 0 & 0 & 0 & 0 & 0 & 17.6 & 0 & 6.2 & 0 & 0 & 0 \\
\hline 24 & 0 & 0 & 0 & 0 & 0 & 0 & 12.4 & 17 & 4 & 0 & 0 & 0 \\
\hline 25 & 0 & 0 & 6.8 & 0 & 0 & 0 & 4 & 13.2 & 0 & 0 & 0 & 0 \\
\hline 26 & 0 & 0 & 19.2 & 0 & 0 & 0 & 12.8 & 9.8 & 14.6 & 0 & 0 & 0 \\
\hline 27 & 0 & 0 & 0 & 0 & 0 & 0 & 11 & 10.4 & 0 & 0 & 0 & 0 \\
\hline 28 & 0 & 0 & 0 & 21.2 & 0 & 0 & 42.8 & 19.6 & 2 & 0 & 0 & 0 \\
\hline 29 & 0 & 0 & 0 & 0 & 0 & 0 & 32 & 18.2 & $\begin{array}{l}36.8 \\
\end{array}$ & 0 & 0 & 0 \\
\hline 30 & 0 & 0 & 0 & 0 & 0 & 0 & 74.2 & 10 & 6.4 & 0 & 0 & 10.4 \\
\hline 31 & 0 & 0 & 9.8 & 0 & 0 & 0 & 3.2 & 4.8 & 0 & 2 & 0 & 6.8 \\
\hline Total & 0 & 0 & 45.2 & 31 & 0 & 39.8 & 1209.6 & 216.4 & 320.6 & 185.6 & 74.2 & 17.2 \\
\hline Grand Total & 2139.6 & & & & & & & & & & & \\
\hline
\end{tabular}




\begin{tabular}{|c|c|c|c|c|c|c|c|c|c|c|c|c|}
\hline \multicolumn{3}{|c|}{ Annual Rainfall for $2010(\mathrm{~mm})$} & \multirow[b]{2}{*}{ March } & \multirow[b]{2}{*}{ April } & \multirow[b]{2}{*}{ May } & \multirow[b]{2}{*}{ June } & \multirow[b]{2}{*}{ July } & \multirow[b]{2}{*}{ August } & \multirow[b]{2}{*}{ September } & \multirow[b]{2}{*}{ October } & \multirow[b]{2}{*}{ November } & \multirow[b]{2}{*}{ December } \\
\hline Day & January & February & & & & & & & & & & \\
\hline 1 & 0 & 0 & 0 & 0 & 0 & 0 & 5.8 & 26.2 & 8.6 & 0 & 0 & 0 \\
\hline 2 & 0 & 0 & 0 & 0 & 0 & 0 & 24.6 & 11.4 & 13.2 & 8.6 & 0 & 0 \\
\hline 3 & 0 & 0 & 0 & 0 & 3 & 0 & 8.2 & 6.4 & 21.8 & 30.2 & 26.2 & 0 \\
\hline 4 & 0 & 0 & 0 & 0 & 0 & 0 & 5.4 & 98.6 & 12 & 13.4 & 0 & 0 \\
\hline 5 & 0 & 0 & 0 & 0 & 0 & 0 & 41.2 & 10.2 & 5.2 & 0 & 12.6 & 0 \\
\hline 6 & 0 & 0 & 0 & 0 & 0 & 0 & 12.6 & 2.8 & 19.4 & 0 & 4.2 & 0 \\
\hline 7 & 0 & 0 & 0 & 0 & 0 & 60 & 13.8 & 5.6 & 16.6 & 0 & 3.8 & 0 \\
\hline 8 & 0 & 0 & 0 & 0 & 0 & 0 & 24 & 38.6 & 16.4 & 0 & 19 & 0 \\
\hline 9 & 0 & 0 & 0 & 0 & 0 & 0 & 0 & 11.8 & 42 & 0 & 24.8 & 0 \\
\hline 10 & 0 & 0 & 0 & 0 & 0 & 0 & 0 & 1.6 & 6.2 & 0 & 0 & 0 \\
\hline 11 & 18.6 & 0 & 0 & 0 & 0 & 0 & 0 & 13 & 7 & 0 & 0 & 0 \\
\hline 12 & 0 & 0 & 0 & 0 & 0 & 7.8 & 0 & 0 & 4.6 & 0 & 11.2 & 0 \\
\hline 13 & 0 & 0 & 0 & 0 & 0 & 0 & 1 & 0 & 6.6 & 0 & 2.8 & 0 \\
\hline 14 & 0 & 0 & 0 & 0 & 0 & 6.4 & 0 & 0 & 1.4 & 0 & 13.6 & 0 \\
\hline 15 & 0 & 0 & 0 & 0 & 0 & 45.6 & 8.4 & 4.6 & 0 & 0 & 3.4 & 0 \\
\hline 16 & 0 & 0 & 0 & 0 & 0 & 39.8 & 1 & 11.6 & 29.8 & 0 & 0 & 0 \\
\hline 17 & 0 & 0 & 0 & 0 & 0 & 27.2 & 3.8 & 1.4 & 2.6 & 0 & 0 & 0 \\
\hline 18 & 0 & 0 & 0 & 0 & 0 & 47.4 & 9.2 & 16.2 & 0 & 0 & 0 & 0 \\
\hline 19 & 0 & 0 & 0 & 0 & 24 & 29.8 & 14.2 & 8.2 & 0 & 3.6 & 0 & 0 \\
\hline 20 & 0 & 0 & 0 & 0 & 0 & 18.6 & 37 & 0 & 0 & 4.2 & 0 & 0 \\
\hline 21 & 0 & 0 & 0 & 0 & 0 & 6.2 & 43.6 & 0 & 0 & 0 & 0 & 0 \\
\hline 22 & 0 & 0 & 0 & 0 & 0 & 1.2 & 32.8 & 6.8 & 0 & 0 & 0 & 0 \\
\hline 23 & 0 & 0 & 0 & 26.8 & 0 & 0 & 42 & 35.2 & 2.8 & 0 & 0 & 0 \\
\hline 24 & 0 & 0 & 0 & 0 & 26.6 & 1.8 & 13.2 & 0 & 64.2 & 0 & 0 & 0 \\
\hline 25 & 0 & 0 & 0 & 6.8 & 0 & 6.4 & 32.4 & 3.8 & 2.8 & 0 & 0 & 0 \\
\hline 26 & 0 & 0 & 0 & 0 & 0 & 14.6 & 65.8 & 38.6 & 5.6 & 0 & 0 & 0 \\
\hline 27 & 0 & 0 & 0 & 0 & 0 & 23.8 & 31.6 & 7.8 & 6.8 & 0 & 0 & 0 \\
\hline 28 & 0 & 0 & 0 & 0 & 0 & 8.2 & 63 & 11.2 & 10.2 & 0 & 0 & 0 \\
\hline 29 & 0 & 0 & 0 & 9.8 & 0 & 30 & 112.4 & 0 & 6.4 & 0 & 0 & 0 \\
\hline 30 & 0 & 0 & 0 & 0 & 0 & 0 & 29.6 & 14 & 5.6 & 0 & 0 & 0 \\
\hline 31 & 0 & 0 & 0 & 0 & 0 & 1.4 & 41 & 65.4 & 0 & 0 & 0 & 0 \\
\hline Total & 18.6 & 0 & 0 & 43.4 & 53.6 & 376.2 & 717.6 & 451 & 317.8 & 60 & 121.6 & 0 \\
\hline Grand Total & 2159.8 & & & & & & & & & & & \\
\hline
\end{tabular}




\begin{tabular}{|c|c|c|c|c|c|c|c|c|c|c|c|c|}
\hline \multicolumn{3}{|c|}{ Annual Rainfall for $2011(\mathrm{~mm})$} & \multirow[b]{2}{*}{ March } & \multirow[b]{2}{*}{ April } & \multirow[b]{2}{*}{ May } & \multirow[b]{2}{*}{ June } & \multirow[b]{2}{*}{ July } & \multirow[b]{2}{*}{ August } & \multirow[b]{2}{*}{ September } & \multirow[b]{2}{*}{ October } & \multirow[b]{2}{*}{ November } & \multirow[b]{2}{*}{ December } \\
\hline Day & January & February & & & & & & & & & & \\
\hline 1 & 0 & 0 & 0 & 0 & 0 & 1 & 3.6 & 19 & 66.2 & 1 & 0 & 0 \\
\hline 2 & 0 & 0 & 0 & 0 & 0 & 0 & 23.6 & 12.6 & 78.8 & 0 & 0 & 0 \\
\hline 3 & 0 & 0 & 0 & 0 & 0 & 65 & 15.4 & 38.4 & 75.6 & 0 & 0 & 0 \\
\hline 4 & 0 & 0 & 0 & 0 & 0 & 9 & 11.8 & 92 & 24.2 & 0 & 6.8 & 0 \\
\hline 5 & 0 & 0 & 0 & 0 & 0 & 34.6 & 3 & 79.4 & 17.6 & 0 & 0 & 0 \\
\hline 6 & 0 & 0 & 0 & 0 & 0 & 40 & 10.2 & 17.8 & 35.4 & 0 & 0 & 0 \\
\hline 7 & 0 & 0 & 0 & 0 & 0 & 20.2 & 44 & 17.2 & 13 & 0 & 0 & 0 \\
\hline 8 & 0 & 0 & 0 & 0 & 0 & 28 & 19 & 21.2 & 13.4 & 0 & 0 & 0 \\
\hline 9 & 0 & 0 & 0 & 0 & 0 & 22 & 9.6 & 9 & 17 & 0 & 0 & 0 \\
\hline 10 & 0 & 0 & 0 & 13.2 & 0 & 40.6 & 1.4 & 3.4 & 2.8 & 11.2 & 0 & 0 \\
\hline 11 & 0 & 0 & 0 & 0 & 0 & $\begin{array}{l}49.8 \\
\end{array}$ & 16.2 & 1.8 & 2.4 & 3.6 & 0 & 0 \\
\hline 12 & 0 & 0 & 0 & 0 & 0 & 25.2 & 8.4 & $\begin{array}{l}4.4 \\
\end{array}$ & 5 & 18 & 0 & 0 \\
\hline 13 & 0 & 0 & 0 & 0 & 0 & 14 & 36.2 & 10.4 & 0 & 24.4 & 0 & 0 \\
\hline 14 & 0 & 0 & 0 & 0 & 0 & 8 & 26.4 & 9.8 & $\begin{array}{l}53.2 \\
\end{array}$ & 0 & 0 & 0 \\
\hline 15 & 0 & 0 & 0 & 27.8 & 0 & 38.4 & 5.4 & 6.6 & 10.2 & 0 & 0 & 0 \\
\hline 16 & 0 & 0 & 0 & 51.2 & 0 & 32.2 & 43.8 & 18.8 & 1.6 & 0 & 0 & 0 \\
\hline 17 & 0 & 0 & 0 & 0 & 0 & 16.2 & 126 & 4.6 & 11 & 25.8 & 0 & 0 \\
\hline 18 & 0 & 0 & 0 & 0 & 0 & 12.2 & 24 & 1.8 & 6.4 & 2.2 & 0 & 0 \\
\hline 19 & 0 & 0 & 0 & 0 & 0 & 7.6 & 43 & 40.2 & 5.8 & 0 & 0 & 0 \\
\hline 20 & 0 & 0 & 0 & 0 & 0 & 5.6 & 9.6 & 7 & 0 & 8 & 0 & 0 \\
\hline 21 & 0 & 0 & 0 & 0 & 0 & 24 & 15.6 & 14.8 & 3.6 & 2.4 & 0 & 0 \\
\hline 22 & 0 & 0 & 0 & 0 & 0 & 38.4 & 15.8 & 1.2 & 1.4 & 0 & 0 & 0 \\
\hline 23 & 0 & 0 & 0 & 0 & 0 & 102 & 36.8 & 1.4 & 0 & 0 & 0 & 0 \\
\hline 24 & 0 & 2 & 0 & 0 & 0 & 9.4 & 19 & 4.6 & 0 & 0 & 0 & 0 \\
\hline 25 & 0 & 2.8 & 0 & 0 & 0 & 22 & 9.8 & 2.8 & 0 & 0 & 0 & 0 \\
\hline 26 & 0 & 0 & 0 & 0 & 0 & 29.6 & 2.6 & 5.6 & 0 & 1.4 & 0 & 0 \\
\hline 27 & 0 & 0 & 0 & 8 & 0 & 36.4 & 1.2 & $\begin{array}{l}4.8 \\
\end{array}$ & 0 & 0 & 0 & 0 \\
\hline 28 & 0 & 0 & 0 & 0 & 5.8 & 24.6 & 6.8 & 33.6 & 0 & 31.2 & 0 & 0 \\
\hline 29 & 0 & 0 & 0 & 0 & 0 & 18 & 5.4 & 17.6 & 0 & 0 & 1.2 & 0 \\
\hline 30 & 0 & 0 & 0 & 0 & 0 & 4.6 & 25.6 & 47 & 0 & 12.4 & 28 & 0 \\
\hline 31 & 0 & 0 & 5 & 0 & 26 & 0 & 4.6 & 49.4 & 0 & 0 & 31.8 & 0 \\
\hline Total & 0 & 4.8 & 5 & 100.2 & 31.8 & 778.6 & 623.8 & 598.2 & 444.6 & 141.6 & 67.8 & 0 \\
\hline \begin{tabular}{|l|} 
Grand Total \\
\end{tabular} & 2796.4 & & & & & & & & & & & \\
\hline
\end{tabular}




\begin{tabular}{|c|c|c|c|c|c|c|c|c|c|c|c|c|}
\hline \multicolumn{3}{|c|}{ Annual Rainfall for $2012(\mathrm{~mm})$} & \multirow[b]{2}{*}{ March } & \multirow[b]{2}{*}{ April } & \multirow[b]{2}{*}{ May } & \multirow[b]{2}{*}{ June } & \multirow[b]{2}{*}{ July } & \multirow[b]{2}{*}{ August } & \multirow[b]{2}{*}{ September } & \multirow[b]{2}{*}{ October } & \multirow[b]{2}{*}{ November } & \multirow[b]{2}{*}{ December } \\
\hline Day & January & February & & & & & & & & & & \\
\hline 1 & 0 & 0 & 0 & 0 & 0 & 0 & 5.6 & 11.6 & 23.4 & 14.2 & 5 & 0 \\
\hline 2 & 0 & 0 & 0 & 0 & 0 & 0 & 33.2 & 13.8 & 9.8 & 3.2 & 61 & 0 \\
\hline 3 & 0 & 0 & 0 & 11.4 & 0 & 0 & 17.8 & 38.6 & 8.4 & 13.8 & 2.8 & 0 \\
\hline 4 & 0 & 0 & 0 & 0 & 0 & 0 & 6.2 & 90.2 & 47 & 7.8 & 0 & 0 \\
\hline 5 & 0 & 0 & 0 & 12.6 & 0 & 2 & 4.4 & 92 & 24.6 & 1.2 & 0 & 0 \\
\hline 6 & 0 & 0 & 0 & 0 & 0 & 6.8 & 3.2 & 45.8 & 10 & 1.4 & 0 & 0 \\
\hline 7 & 0 & 0 & 0 & 0 & 0 & 11.8 & 2.8 & 85.6 & 13 & 0 & 0 & 0 \\
\hline 8 & 0 & 0 & 0 & 0 & 0 & 11.4 & 15 & 15.2 & $\begin{array}{ll}11.8 \\
\end{array}$ & 0 & 0 & 0 \\
\hline 9 & 0 & 0 & 0 & 0 & 0 & 1 & 1.6 & 14.4 & 7.8 & 0 & 0 & 0 \\
\hline 10 & 0 & 0 & 0 & 0 & 0 & 0 & 13 & 25.8 & 13.4 & 0 & 0 & 0 \\
\hline 11 & 0 & 0 & 0 & 0 & 0 & 0 & 6.6 & 40.8 & $\begin{array}{l}3.8 \\
\end{array}$ & 0 & 0 & 0 \\
\hline 12 & 0 & 0 & 0 & 0 & 14.6 & 6.6 & 9.4 & 30 & 7.2 & 0 & 0 & 0 \\
\hline 13 & 0 & 0 & 0 & 0 & 0 & 17 & 0 & 19.8 & 21.6 & 0 & 0 & 0 \\
\hline 14 & 0 & 0 & 0 & 0 & 0 & 0 & 0 & 2 & 4 & 0 & 0 & 0 \\
\hline 15 & 0 & 0 & 0 & 0 & 0 & 0 & 1.2 & 0 & 6.2 & 0 & 0 & 0 \\
\hline 16 & 0 & 0 & 0 & 9.6 & 0 & 3.6 & 10 & 2.2 & 7 & 0 & 0 & 0 \\
\hline 17 & 0 & 0 & 0 & 5.2 & 0 & 2.4 & 0.6 & 1 & 5.4 & 0 & 0 & 0 \\
\hline 18 & 0 & 0 & 0 & 8.4 & 0 & 28.4 & 12.4 & 8.8 & 2.6 & 0 & 0 & 0 \\
\hline 19 & 0 & 0 & 0 & 14.2 & 0 & 53.8 & 13.8 & 3.8 & 0 & 0 & 0 & 0 \\
\hline 20 & 0 & 0 & 0 & 0 & 0 & 4 & 29.4 & 3 & 8.2 & 4.6 & 0 & 0 \\
\hline 21 & 0 & 0 & 0 & 0 & 0 & 2.6 & 121.8 & 2.2 & 0 & 0 & 0 & 0 \\
\hline 22 & 0 & 0 & 0 & 0 & 0 & 0 & 31.8 & 0 & 0 & 0 & 0 & 0 \\
\hline 23 & 0 & 0 & 0 & 0 & 0 & 0 & 6.2 & 0 & 0 & 0 & 0 & 0 \\
\hline 24 & 0 & 0 & 0 & 0 & 0 & 23.8 & 15.8 & 0 & 0 & 0 & 0 & 0 \\
\hline 25 & 0 & 0 & 0 & 3 & 0 & 7.6 & 4 & 0 & 0 & 0 & 0 & 0 \\
\hline 26 & 0 & 0 & 0 & 1.4 & 0 & 9.2 & 32.2 & 3 & 0 & 0 & 0 & 0 \\
\hline 27 & 0 & 0 & 0 & 0 & 0 & 6.2 & 71.8 & 2.8 & 0 & 0 & 0 & 0 \\
\hline 28 & 0 & 0 & 0 & 8.2 & 0 & 8 & 11 & 24.8 & 19.2 & 0 & 0 & 0 \\
\hline 29 & 0 & 0 & 0 & 0 & 0 & 14.2 & 15.4 & 48.2 & 1.8 & 0 & 0 & 0 \\
\hline 30 & 0 & 0 & 0 & 0 & 0 & 8.4 & 5.4 & 10.2 & 18 & 0 & 0 & 0 \\
\hline 31 & 0 & 0 & 0 & 0 & 0 & 0 & 12 & 14 & 0 & 0 & 0 & 0 \\
\hline Total & 0 & 0 & 0 & 74 & 14.6 & 228.8 & 513.6 & 649.6 & 274.2 & 46.2 & 68.8 & 0 \\
\hline Grand Total & 1869.8 & & & & & & & & & & & \\
\hline
\end{tabular}




\begin{tabular}{|c|c|c|c|c|c|c|c|c|c|c|c|c|}
\hline \multicolumn{3}{|c|}{ Annual Rainfall for $2013(\mathrm{~mm})$} & \multirow[b]{2}{*}{ March } & \multirow[b]{2}{*}{ April } & \multirow[b]{2}{*}{ May } & \multirow[b]{2}{*}{ June } & \multirow[b]{2}{*}{ July } & \multirow[b]{2}{*}{ August } & \multirow[b]{2}{*}{ September } & \multirow[b]{2}{*}{ October } & \multirow[b]{2}{*}{ November } & \multirow[b]{2}{*}{ December } \\
\hline Day & January & February & & & & & & & & & & \\
\hline 1 & 34 & 0 & 0 & 0 & 0 & 18.2 & 23.8 & 29.4 & 0 & 2.8 & 0 & 0 \\
\hline 2 & 0 & 0 & 0 & 0 & 0 & 0 & 20 & 46.2 & 0 & 0 & 0 & 0 \\
\hline 3 & 0 & 0 & 0 & 0 & 0 & 36.4 & 282.2 & 14.8 & 0 & 0 & 18.4 & 0 \\
\hline 4 & 0 & 0 & 0 & 0 & 0 & 1.4 & 68.4 & 54.4 & 0 & 2.6 & 0 & 0 \\
\hline 5 & 0 & 0 & 0 & 0 & 0 & 0 & 23.6 & 8.8 & 2 & 1.8 & 0 & 0 \\
\hline 6 & 0 & 0 & 0 & 0 & 0 & 0 & 35.2 & 11.4 & 4.8 & 23.8 & 0 & 0 \\
\hline 7 & 0 & 0 & 0 & 0 & 0 & 4 & 9.6 & 8.2 & 0 & 1.6 & 0 & 0 \\
\hline 8 & 0 & 0 & 0 & 0 & 0 & 30.6 & 7.2 & 3.2 & 28.8 & 0 & 0 & 0 \\
\hline 9 & 0 & 0 & 0 & 0 & 25.2 & 21.2 & 7 & 7.4 & 4 & 0 & 0 & 0 \\
\hline 10 & 0 & 3.8 & 0 & 0 & 0 & 4.4 & 13.4 & 2 & 12.2 & 0 & 0 & 0 \\
\hline 11 & 0 & 0 & 0 & 0 & 0 & 15.6 & 44 & 4.4 & 3.8 & 0 & 0 & 0 \\
\hline 12 & 0 & 0 & 0 & 0 & 0 & 7 & 32.8 & 3 & 1.2 & 7.2 & 0 & 0 \\
\hline 13 & 0 & 0 & 0 & 0 & 0 & 11.4 & 22.8 & 16.4 & 7.2 & 0 & 0 & 0 \\
\hline 14 & 0 & 0 & 0 & 0 & 0 & 48 & 17.6 & 15.4 & 1.2 & 1.4 & 0 & 0 \\
\hline 15 & 0 & 8.4 & 0 & 0 & 0 & 28.4 & 7.8 & 4.8 & 14.8 & 0 & 0 & 0 \\
\hline 16 & 0 & 0 & 0 & 0 & 0 & 17.8 & 13 & 11.8 & 0 & 0 & 0 & 0 \\
\hline 17 & 0 & 0 & 0 & 0 & 0 & 22.4 & 26 & 17.4 & 8.8 & 0 & 0 & 0 \\
\hline 18 & 0 & 0 & 0 & 0 & 0 & 19.2 & 55.8 & 20 & 31.2 & 0 & 0 & 0 \\
\hline 19 & 0 & 0 & 0 & 0 & 0 & 10.4 & 27.6 & 7.4 & 5.8 & 0 & 0 & 0 \\
\hline 20 & 0 & 0 & 0 & 0 & 0 & 18 & 35 & 30.4 & 33.2 & 0 & 0 & 0 \\
\hline 21 & 0 & 0 & 0 & 0 & 23.4 & 3.2 & 34 & 12.4 & 19.6 & 0 & 0 & 0 \\
\hline 22 & 0 & 0 & 0 & 0 & 0 & 0 & 18.4 & 15.6 & 16 & 0 & 0 & 0 \\
\hline 23 & 0 & 0 & 0 & 0 & 0 & 8.4 & 72 & 16.8 & 5.6 & 4.6 & 0 & 0 \\
\hline 24 & 0 & 0 & 0 & 0 & 0 & 22.2 & 42 & 16.2 & 12.4 & 29.2 & 0 & 0 \\
\hline 25 & 0 & 0 & 0 & 0 & 0 & 33.2 & 56.4 & 4.4 & 13.6 & 11 & 0 & 0 \\
\hline 26 & 0 & 0 & 0 & 0 & 0 & 49.2 & 51.6 & 2.4 & 0 & 3.8 & 0 & 0 \\
\hline 27 & 0 & 0 & 0 & 0 & 0 & 48.4 & 46.2 & 1.2 & 0 & 0 & 9.2 & 0 \\
\hline 28 & 0 & 0 & 0 & 0 & 1.4 & 11 & 56.2 & 2.2 & 0 & 0 & 0 & 0 \\
\hline 29 & 0 & 0 & 0 & 0 & 6 & 3.2 & 33.6 & 8.4 & 0 & 0 & 0 & 0 \\
\hline 30 & 0 & 0 & 0 & 0 & 0 & 21.2 & 13.2 & 0 & 3.8 & 0 & 0 & 0 \\
\hline 31 & 0 & 0 & 0 & 0 & 0 & 0 & 30.4 & 0 & 0 & 0 & 0 & 0 \\
\hline Total & 34 & 12.2 & 0 & 0 & 56 & 514.4 & 1226.8 & 396.4 & 230 & 89.8 & 27.6 & 0 \\
\hline Grand Total & 2587.2 & & & & & & & & & & & \\
\hline
\end{tabular}




\begin{tabular}{|c|c|c|c|c|c|c|c|c|c|c|c|c|}
\hline \multicolumn{3}{|c|}{ Annual Rainfall for $2014(\mathrm{~mm})$} & \multirow[b]{2}{*}{ March } & \multirow[b]{2}{*}{ April } & \multirow[b]{2}{*}{ May } & \multirow[b]{2}{*}{ June } & \multirow[b]{2}{*}{ July } & \multirow[b]{2}{*}{ August } & \multirow[b]{2}{*}{ September } & \multirow[b]{2}{*}{ October } & \multirow[b]{2}{*}{ November } & \multirow[b]{2}{*}{ December } \\
\hline Day & January & February & & & & & & & & & & \\
\hline 1 & 0 & 0 & 0 & 0 & 0 & 0 & 0 & 96.6 & 32.4 & 29.2 & 0 & 0 \\
\hline 2 & 0 & 0 & 0 & 0 & 0 & 4.4 & 0 & 37.2 & 6.6 & 1.8 & 0 & 0 \\
\hline 3 & 0 & 0 & 0 & 0 & 3.4 & 2.8 & 4.8 & 25.2 & 8.6 & 0 & 0 & 0 \\
\hline 4 & 0 & 0 & 0 & 0 & 24.4 & 1.4 & 22 & 34.8 & 13.8 & 0 & 0 & 0 \\
\hline 5 & 0 & 0 & 0 & 0 & 0 & 0 & 0 & 36.4 & 33.4 & 24.4 & 0 & 0 \\
\hline 6 & 0 & 0 & 0 & 0 & 36.8 & 0 & 2.2 & 68.4 & 16.2 & 27.6 & 0 & 0 \\
\hline 7 & 0 & 0 & 0 & 0 & 3.2 & 0 & 0 & 35.2 & 24.8 & 9.4 & 0 & 0 \\
\hline 8 & 0 & 0 & 0 & 5.2 & 29.2 & 0 & 18.2 & 36.6 & 2.2 & 0 & 0 & 0 \\
\hline 9 & 0 & 0 & 0 & 0 & 42.2 & 0 & 3 & 8.4 & 3 & 0 & 0 & 0 \\
\hline 10 & 0 & 0 & 0 & 0 & 0 & 7.2 & 12.8 & 8 & 0 & 41.6 & 0 & 0 \\
\hline 11 & 0 & 0 & 4.2 & 0 & 0 & $\begin{array}{l}3.8 \\
\end{array}$ & 37.8 & 19.4 & 4.6 & 14.6 & 0 & 0 \\
\hline 12 & 0 & 0 & 0 & 0 & 0 & 0 & 22 & 4.6 & 9 & 24.4 & 0 & 8.4 \\
\hline 13 & 0 & 0 & 0 & 0 & 0 & 9.8 & 14.6 & 4 & 2.6 & 0 & 0 & 7.2 \\
\hline 14 & 0 & 0 & 0 & 0 & 0 & 6.2 & 38.8 & 2.8 & 0 & 0 & 1.8 & 15.2 \\
\hline 15 & 0 & 0 & 0 & 0 & 0 & 22 & 54.8 & 2 & 0 & 0 & 24.6 & 0 \\
\hline 16 & 0 & 0 & 0 & 3.2 & 0 & 0 & 73.8 & 4 & 0 & 0 & 0 & 0 \\
\hline 17 & 0 & 0 & 0 & 0 & 0 & 25.4 & 28.6 & 12.4 & 10.2 & 0 & 0 & 0 \\
\hline 18 & 0 & 0 & 0 & 0 & 0 & 6.4 & 34.4 & 0 & 0 & 9 & 0 & 0 \\
\hline 19 & 0 & 0 & 0 & 0 & 0 & 76.6 & 17.4 & 0 & 11.8 & 0 & 0 & 0 \\
\hline 20 & 0 & 0 & 0 & 6.8 & 0 & $\begin{array}{l}51.8 \\
\end{array}$ & 18 & 14.4 & 1.4 & 0 & 0 & 0 \\
\hline 21 & 0 & 0 & 0 & 0 & 0 & 35 & 70.2 & 0 & 0 & 0 & 0 & 0 \\
\hline 22 & 0 & 0 & 0 & 0 & 26.2 & 52.4 & 98.6 & 7.2 & 0 & 0 & 0 & 0 \\
\hline 23 & 0 & 0 & 0 & 0 & 0 & 4 & 90.8 & 30 & 0 & 0 & 0 & 0 \\
\hline 24 & 0 & 0 & 0 & 0 & 0 & 1.4 & 76.8 & 1.4 & 1.8 & 0 & 0 & 0 \\
\hline 25 & 0 & 0 & 0 & 0 & 0 & 0 & 41 & 9.6 & 37 & 5.6 & 0 & 0 \\
\hline 26 & 0 & 0 & 0 & 2.4 & 0 & 0 & 38.6 & 31 & 1.4 & 23.8 & 0 & 0 \\
\hline 27 & 0 & 0 & 0 & $\begin{array}{l}11.8 \\
\end{array}$ & 0 & 0 & 5.2 & 12.8 & 2.6 & 1.4 & 0 & 0 \\
\hline 28 & 0 & 0 & 0 & 0 & 5.2 & 0 & 3.8 & 13.2 & 0 & 0 & 0 & 0 \\
\hline 29 & 0 & 0 & 0 & 0 & 0 & 0 & 43.8 & 45.2 & 0 & 0 & 0 & 0 \\
\hline 30 & 0 & 0 & 0 & 12.2 & 0 & 0 & 28.6 & 15.8 & 17.8 & 0 & 0 & 0 \\
\hline 31 & 0 & 0 & 0 & 0 & 0 & 0 & 29.2 & 44.8 & 0 & 0 & 0 & 0 \\
\hline Total & 0 & 0 & 4.2 & 41.6 & 170.6 & 310.6 & 929.8 & 661.4 & 241.2 & 212.8 & 26.4 & 30.8 \\
\hline Grand Total & 2629.4 & & & & & & & & & & & \\
\hline
\end{tabular}




\begin{tabular}{|c|c|c|c|c|c|c|c|c|c|c|c|c|}
\hline \multicolumn{3}{|c|}{ Annual Rainfall for $2016(\mathrm{~mm})$} & \multirow[b]{2}{*}{ March } & \multirow[b]{2}{*}{ April } & \multirow[b]{2}{*}{ May } & \multirow[b]{2}{*}{ June } & \multirow[b]{2}{*}{ July } & \multirow[b]{2}{*}{ August } & \multirow[b]{2}{*}{ September } & \multirow[b]{2}{*}{ October } & \multirow[b]{2}{*}{ November } & \multirow[b]{2}{*}{ December } \\
\hline Day & January & February & & & & & & & & & & \\
\hline 1 & 0 & 0 & 0 & 0 & 0 & 0 & 23.8 & 14.2 & 7.4 & 0 & 0 & 0 \\
\hline 2 & 0 & 0 & 0 & 0 & 0 & 1.4 & 46 & 16 & 2 & 0 & 0 & 0 \\
\hline 3 & 0 & 0 & 0 & 0 & 0 & 14.6 & 15.8 & 15 & 2.2 & 0 & 2.2 & 0 \\
\hline 4 & 0 & 0 & 0 & 0 & 0 & 17.2 & 33 & 44.4 & 2.8 & 0 & 0 & 0 \\
\hline 5 & 0 & 0 & 0 & 0 & 0 & 0 & 79.4 & 39.2 & 0 & 0 & 0 & 0 \\
\hline 6 & 0 & 0 & 0 & 0 & 0 & 0 & 40 & 4 & 0 & 0 & 0 & 0 \\
\hline 7 & 0 & 0 & 0 & 0 & 0 & 0 & 6.4 & 10.8 & 0 & 0 & 0 & 0 \\
\hline 8 & 0 & 0 & 0 & 0 & 0 & 0 & 5 & 24 & 6.4 & 0 & 0 & 0 \\
\hline 9 & 0 & 0 & 0 & 0 & 0 & 43.4 & $\begin{array}{l}4.6 \\
\end{array}$ & 18 & 0 & 0 & 0 & 0 \\
\hline 10 & 0 & 0 & 0 & 0 & 0 & 4.8 & 7 & 8.4 & 0 & 13.2 & 0 & 0 \\
\hline 11 & 0 & 0 & 0 & 0 & 0 & 3.4 & 6.2 & 9 & 0 & 20.2 & 0 & 0 \\
\hline 12 & 0 & 0 & 0 & 0 & 0 & 8.6 & 20 & 11.4 & 0 & 0 & 0 & 0 \\
\hline 13 & 0 & 0 & 0 & 0 & 37.2 & 2 & 5 & 18.2 & 0 & 0 & 0 & 0 \\
\hline 14 & 0 & 0 & 0 & 0 & 0 & 2.4 & 5.8 & 10.4 & 0 & 10.8 & 0 & 0 \\
\hline 15 & 0 & 0 & 0 & 0 & 7.6 & 6.4 & 4 & 4.6 & 3.6 & 0 & 0 & 0 \\
\hline 16 & 0 & 0 & 0 & 0 & 0 & 0 & 0 & 3.6 & 5.4 & 0 & 3.8 & 3.2 \\
\hline 17 & 0 & 0 & 0 & 0 & 9.4 & 0 & 1.4 & 2.6 & 4.4 & 0 & 40.8 & 0 \\
\hline 18 & 0 & 0 & 0 & 0 & 14.4 & 0 & 0 & 4.4 & 4.8 & 0 & 0 & 0 \\
\hline 19 & 0 & 0 & 0 & 0 & 5.8 & 4.6 & 5.8 & 4 & 14 & 0 & 0 & 0 \\
\hline 20 & 0 & 0 & 0 & 0 & 2 & 2 & 6.8 & 1.4 & 6.4 & 0 & 0 & 0 \\
\hline 21 & 0 & 0 & 0 & 0 & 0 & 13 & 10 & 0 & 10 & 0 & 0 & 0 \\
\hline 22 & 0 & 0 & 0 & 0 & 0 & 22.2 & 11.2 & 25.2 & 13 & 0 & 0 & 0 \\
\hline 23 & 0 & 0 & 0 & 0 & 0 & 10.4 & 12.4 & 10.8 & $\begin{array}{l}4.2 \\
\end{array}$ & 0 & 0 & 0 \\
\hline 24 & 0 & 0 & 0 & 0 & 0 & 5.6 & 18 & 35.6 & 14.4 & 0 & 0 & 0 \\
\hline 25 & 0 & 0 & 0 & 0 & 0 & 6 & 27.8 & 6.8 & 18.8 & 0 & 0 & 0 \\
\hline 26 & 0 & 0 & 0 & 0 & 0 & 11.4 & 2 & 3.8 & 4.8 & 0 & 0 & 0 \\
\hline 27 & 0 & 0 & 0 & 0 & 0 & 26.2 & 1.4 & 2 & 0 & 0 & 0 & 0 \\
\hline 28 & 0 & 0 & 0 & 0 & 0 & 32.6 & 1.2 & 6.4 & 0 & 0 & 0 & 0 \\
\hline 29 & 0 & 0 & 0 & 0 & 0 & 50.6 & 3.6 & 2.6 & 0 & 0 & 0 & 0 \\
\hline 30 & 0 & 0 & 0 & 0 & 0 & 56.8 & 1 & 1.4 & 0 & 0 & 0 & 0 \\
\hline 31 & 0 & 0 & 0 & 0 & 0 & 0 & 7 & 12.6 & 0 & 0 & 0 & 0 \\
\hline Total & 0 & 0 & 0 & 0 & 76.4 & 345.6 & 411.6 & 370.8 & 124.6 & 44.2 & 46.8 & 3.2 \\
\hline Grand Total & 1423.2 & & & & & & & & & & & \\
\hline
\end{tabular}




\begin{tabular}{|c|c|c|c|c|c|c|c|c|c|c|c|c|}
\hline \multicolumn{3}{|c|}{ Annual Rainfall for $2015(\mathrm{~mm})$} & \multirow[b]{2}{*}{ March } & \multirow[b]{2}{*}{ April } & \multirow[b]{2}{*}{ May } & \multirow[b]{2}{*}{ June } & \multirow[b]{2}{*}{ July } & \multirow[b]{2}{*}{ August } & \multirow[b]{2}{*}{ September } & \multirow[b]{2}{*}{ October } & \multirow[b]{2}{*}{ November } & \multirow[b]{2}{*}{ December } \\
\hline Day & January & February & & & & & & & & & & \\
\hline 1 & 0 & 0 & 0 & 0 & 0 & 0 & 18.4 & 16.4 & 0 & 0 & 42.8 & 0 \\
\hline 2 & 0 & 0 & 2.4 & 0 & 0 & 0 & 8.4 & 3.2 & 0 & 8.6 & 0 & 0 \\
\hline 3 & 0 & 0 & 0 & 0 & 0 & 1.4 & 9.2 & 3.4 & 0 & 0 & 10.4 & 0 \\
\hline 4 & 0 & 0 & 0 & 0 & 0 & 0 & 2 & 12 & 0 & 0 & 0 & 0 \\
\hline 5 & 0 & 0 & 0 & 0 & 4.4 & 1.8 & 0 & 21.8 & 0 & 5.4 & 52.6 & 0 \\
\hline 6 & 0 & 0 & 0 & 0 & 4.2 & 0 & 0 & 14.4 & 0 & 23.2 & 0 & 0 \\
\hline 7 & 0 & 0 & 0 & 0 & 0 & 0 & 0 & 13 & 0 & 2.6 & 0 & 0 \\
\hline 8 & 0 & 0 & 0 & 0 & 6.8 & 0 & 4.2 & 13.4 & 4.6 & 8 & 0 & 0 \\
\hline 9 & 0 & 0 & 1.2 & 0 & 0 & 17 & 17.2 & 41.6 & 3.8 & 0 & 0 & 0 \\
\hline 10 & 0 & 0 & 3.2 & 0 & 0 & 8.4 & 27 & 29.4 & 18.4 & 2 & 0 & 0 \\
\hline 11 & 0 & 0 & 0 & 0 & 0 & 0 & 20 & 26.6 & 16.8 & 0 & 0 & 0 \\
\hline 12 & 0 & 0 & 0 & 0 & 0 & 0 & 14 & 10.4 & 0 & 0 & 0 & 0 \\
\hline 13 & 0 & 0 & 0 & 0 & 27.8 & 3.8 & 1.8 & 8.4 & 0 & 0 & 0 & 0 \\
\hline 14 & 0 & 0 & 0 & 0 & 5.8 & 37.2 & 1.2 & 13.8 & 27 & 0 & 0 & 0 \\
\hline 15 & 0 & 0 & 0 & 0 & 0 & 13.8 & 16.6 & 6.4 & $\begin{array}{l}38.8 \\
\end{array}$ & 0 & 0 & 0 \\
\hline 16 & 0 & 0 & 0 & 0 & 0 & 3.8 & 10.8 & 5 & 35 & 0 & 0 & 0 \\
\hline 17 & 0 & 0 & 0 & 0 & 4.6 & 9 & 13.8 & 1.4 & 8.6 & 0 & 0 & 0 \\
\hline 18 & 0 & 0 & 0 & 8.2 & 0 & 38 & 23.6 & 0 & 11 & 0 & 0 & 0 \\
\hline 19 & 0 & 0 & 0 & 0 & 2.8 & 40 & 9.2 & 0 & 0 & 0 & 0 & 0 \\
\hline 20 & 0 & 0 & 0 & 0 & 0 & 61.2 & 21 & 15.8 & 5.4 & 0 & 0 & 0 \\
\hline 21 & 0 & 0 & 0 & 0 & 0 & 74.2 & 7 & 0 & 6 & 0 & 0 & 0 \\
\hline 22 & 0 & 0 & 0 & 0 & 0 & 126.4 & 22.8 & 10.6 & 0 & 0 & 0 & 0 \\
\hline 23 & 0 & 0 & 0 & 0 & 0 & 94.4 & 11 & 0 & 0 & 0 & 0 & 0 \\
\hline 24 & 0 & 0 & 0 & 16.6 & 0 & 79 & 6.2 & 16 & 0 & 0 & 0 & 0 \\
\hline 25 & 0 & 0 & 2.8 & 0 & 0 & 55 & 17.8 & 0 & 0 & 0 & 0 & 0 \\
\hline 26 & 0 & 0 & 0 & 0 & 0 & 31.4 & 3.4 & 2.6 & 0 & 0 & 0 & 0 \\
\hline 27 & 0 & 0 & 0 & 0 & 0 & 8.4 & 48.4 & 7 & 0 & 0 & 0 & 0 \\
\hline 28 & 0 & 0 & 0 & 0 & 0 & 3.8 & 4.8 & 8 & 19 & 0 & 0 & 0 \\
\hline 29 & 0 & 0 & 0 & 0 & 0 & 4.4 & 11.8 & 3.8 & 0 & 0 & 0 & 0 \\
\hline 30 & 0 & 0 & 0 & 0 & 0 & 0 & 6.8 & 4.8 & 0 & 6.8 & 0 & 0 \\
\hline 31 & 0 & 0 & 16.2 & 0 & 0 & 0 & 10 & 0 & 0 & 10 & 0 & 0 \\
\hline Total & 0 & 0 & 25.8 & 24.8 & 56.4 & 712.4 & 368.4 & 309.2 & 194.4 & 66.6 & 105.8 & 0 \\
\hline Grand Total & 1863.8 & & & & & & & & & & & \\
\hline
\end{tabular}




\begin{tabular}{|c|c|c|c|c|c|c|c|c|c|c|c|c|}
\hline \multicolumn{3}{|c|}{ Annual Rainfall for $2017(\mathrm{~mm})$} & \multirow[b]{2}{*}{ March } & \multirow[b]{2}{*}{ April } & \multirow[b]{2}{*}{ May } & \multirow[b]{2}{*}{ June } & \multirow[b]{2}{*}{ July } & \multirow[b]{2}{*}{ August } & \multirow[b]{2}{*}{ September } & \multirow[b]{2}{*}{ October } & \multirow[b]{2}{*}{ November } & \multirow[b]{2}{*}{ December } \\
\hline Day & January & February & & & & & & & & & & \\
\hline 1 & 0 & 0 & 0 & 0 & 0 & 0 & 27.2 & 8 & 3.2 & 55.4 & 0 & 0 \\
\hline 2 & 0 & 0 & 0 & 0 & 0 & 41.6 & 88 & 0 & 0 & 44 & 0 & 0 \\
\hline 3 & 0 & 0 & 0 & 0 & 0 & 5.2 & 36 & 3.4 & 0 & 0 & 0 & 0 \\
\hline 4 & 0 & 0 & 0 & 0 & 0 & 0 & 14.6 & 40 & 5 & 4.8 & 0 & 0 \\
\hline 5 & 0 & 0 & 0 & 0 & 0 & 0 & 21.4 & 19.2 & 0 & 0 & 0 & 0 \\
\hline 6 & 0 & 0 & 0 & 0 & 0 & 0 & 26 & 13 & 0 & 0 & 0 & 0 \\
\hline 7 & 0 & 0 & 0 & 0 & 7 & 10 & 22.8 & 10.8 & 0 & 78 & 0 & 0 \\
\hline 8 & 0 & 0 & 0 & 0 & 1.6 & 2.2 & 0 & 9.2 & 42.8 & 0 & 0 & 0 \\
\hline 9 & 0 & 0 & 0 & 0 & 0 & 0 & 3 & 0 & 1.6 & 0 & 0 & 0 \\
\hline 10 & 0 & 0 & 0 & 0 & 0 & 20.6 & 0 & 0 & 1.2 & 0 & 0 & 0 \\
\hline 11 & 0 & 0 & 0 & 0 & 1.4 & 34.6 & 4.2 & 0 & 2.2 & 0 & 0 & 0 \\
\hline 12 & 0 & 0 & 0 & 0 & 0 & 92.8 & 16 & 17.2 & 14 & 2.8 & 0 & 0 \\
\hline 13 & 0 & 0 & 0 & 0 & 0 & 42.4 & 23.8 & 0 & 40.6 & 0 & 0 & 0 \\
\hline 14 & 0 & 0 & 0 & 0 & 0 & 3 & 32.4 & 0 & 1.4 & 16.8 & 0 & 0 \\
\hline 15 & 0 & 0 & 0 & 0 & 5.4 & 0 & 71.8 & 0 & 9 & 15.8 & 2.8 & 0 \\
\hline 16 & 0 & 0 & 0 & 0 & 0 & 2.8 & 63.6 & 0 & 13 & 51.6 & 0 & 0 \\
\hline 17 & 0 & 0 & 0 & 0 & 0 & 15 & 29.8 & 6.2 & 11.4 & 0 & 10 & 0 \\
\hline 18 & 0 & 0 & 0 & 0 & 0 & 29.4 & 49 & 14 & 12.8 & 0 & 0 & 0 \\
\hline 19 & 0 & 0 & 0 & 0 & 0 & 2.6 & 152 & 0 & 8 & 0 & 0 & 0 \\
\hline 20 & 0 & 0 & 0 & 0 & 0 & 6.8 & 141.4 & 17 & 8.8 & 0 & 0 & 0 \\
\hline 21 & 0 & 0 & 0 & 0 & 0 & 18.2 & 66 & 10.2 & 19 & 0 & 0 & 0 \\
\hline 22 & 0 & 0 & 0 & 0 & 0 & 3.4 & 28.2 & 11 & 3.6 & 0 & 0 & 0 \\
\hline 23 & 0 & 0 & 0 & 0 & 0 & 4.6 & 12.8 & 30 & 0 & 0 & 0 & 0 \\
\hline 24 & 0 & 0 & 0 & 0 & 12.4 & 23 & 15 & 23.4 & 0 & 0 & 0 & 0 \\
\hline 25 & 0 & 0 & 0 & 0 & 0 & 86 & 44.6 & 27.6 & 3 & 4.8 & 0 & 0 \\
\hline 26 & 0 & 0 & 0 & 0 & 0 & 70.6 & 16.8 & 10.4 & 54.8 & 5.4 & 0 & 0 \\
\hline 27 & 0 & 0 & 0 & 0 & 0 & 49 & 8.2 & 23.8 & 48.4 & 0 & 0 & 0 \\
\hline 28 & 0 & 0 & 0 & 0 & 0 & 20.6 & 2.2 & 34 & 0 & 0 & 0 & 0 \\
\hline 29 & 0 & 0 & 0 & 0 & 0 & 58.8 & 13 & 49.4 & 48 & 0 & 0 & 0 \\
\hline 30 & 0 & 0 & 0 & 0 & 0 & 42 & 0 & 74.6 & 4.2 & 0 & 0 & 0 \\
\hline 31 & 0 & 0 & 0 & 0 & 10.2 & 0 & 8.8 & 7.4 & 0 & 0 & 0 & 0 \\
\hline Total & 0 & 0 & 0 & 0 & 38 & 685.2 & 1038.6 & 459.8 & 356 & 279.4 & 12.8 & 0 \\
\hline Grand Total & 2869.8 & & & & & & & & & & & \\
\hline
\end{tabular}




\begin{tabular}{|c|c|c|c|c|c|c|c|c|c|c|c|}
\hline & $\begin{array}{c}\text { Surface } \\
\text { Area } \\
\left(\mathrm{m}^{2}\right)\end{array}$ & $\begin{array}{c}\text { Tank } \\
\text { Condition } \\
\end{array}$ & $\begin{array}{c}\text { Water } \\
\text { Holding } \\
\text { Capacity } \\
\text { (Acre-foot) }\end{array}$ & $\begin{array}{l}\text { Vegetation } \\
\text { Health }\end{array}$ & $\begin{array}{c}\text { Wildlife Habitat } \\
\text { Health }\end{array}$ & $\begin{array}{c}\text { Potential } \\
\text { Acreage } \\
\text { Irrigated } \\
\end{array}$ & $\begin{array}{c}\text { Access } \\
\text { and } \\
\text { Convenienc } \\
\mathrm{e} \\
\end{array}$ & $\begin{array}{c} \\
\text { Usabil } \\
\text { ity }\end{array}$ & $\begin{array}{c}\text { Potential } \\
\text { Storage } \\
\text { (Acre-foot) }\end{array}$ & $\begin{array}{c}\text { Ratio of Current to Potential } \\
\text { Storage (\%) }\end{array}$ & $\begin{array}{c}\text { Estimated Cost of } \\
\text { De-siltation } \\
(\text { Lakh Rs. })^{1} \\
\end{array}$ \\
\hline $\begin{array}{l}\text { Gadigehol } \\
\text { e }\end{array}$ & 713.5 & 2 & 0.97 & 2 & 1 & 6 & 1 & 1 & 1.41 & 69 & 1.06 \\
\hline $\begin{array}{l}\text { Bugadima } \\
\text { ne }\end{array}$ & 1040.7 & 4 & 4.7 & 2 & 2 & 53 & 2 & 3 & 9.41 & 50 & 1.54 \\
\hline Kibbali & 219.3 & 4 & 1.16 & 4 & 4 & 30 & 2 & 4 & 1.87 & 62 & 0.33 \\
\hline Ashimane & 631.3 & 5 & 1.16 & 5 & 5 & 9 & 2 & 4 & 1.87 & 62 & 0.94 \\
\hline $\begin{array}{l}\text { Halige } \\
\text { Devari }\end{array}$ & 831.9 & 4 & 0.82 & 3 & 3 & 4 & 5 & 3 & 1.02 & 80 & 1.23 \\
\hline $\begin{array}{l}\text { Keri } \\
\text { Keshinam }\end{array}$ & 1384.4 & 5 & 4.78 & 5 & 4 & 7 & 4 & 5 & 4.78 & 100 & 2.05 \\
\hline $\begin{array}{l}\text { ane } \\
\text { Appuraya }\end{array}$ & 1094.5 & 4 & 0.67 & 3 & 3 & 50 & 3 & 3 & 1.35 & 50 & 1.62 \\
\hline $\begin{array}{l}\text { najaddi } \\
\text { Hakkiman }\end{array}$ & 4313.8 & 3 & 10.65 & 4 & 3 & 4 & 2 & 2 & 21.31 & 50 & 6.40 \\
\hline $\begin{array}{l}\text { e \#1 } \\
\text { Hakkiman }\end{array}$ & 1224.5 & 3 & 0.75 & 3 & 4 & 8 & 3 & 2 & 1.51 & 50 & 1.82 \\
\hline Emme & 4784.6 & 4 & 3.54 & 5 & 4 & 12 & 5 & 5 & 7.09 & 50 & 7.10 \\
\hline Jaanamaki & 7118.2 & 4 & 15.83 & 5 & 5 & 21 & 5 & 3 & 26.38 & 60 & 10.56 \\
\hline Choudi & 2906 & 1 & 7.8 & 2 & 2 & 4 & 5 & 4 & 12.92 & 60 & 4.31 \\
\hline Malenalli & 1859.4 & 2 & 1.83 & 3 & 2 & 10 & 5 & 1 & 3.67 & 50 & 2.76 \\
\hline $\begin{array}{l}\text { Arsapura } \\
\text { Nagarakur }\end{array}$ & 1439.1 & 1 & 2.66 & 4 & 4 & 5 & 2 & 2 & 5.33 & 50 & 2.14 \\
\hline a & 2714.2 & 3 & 8.38 & 2 & 2 & 30 & 2 & 1 & 13.41 & 62 & 4.03 \\
\hline $\begin{array}{l}\text { Beerala } \\
\text { Mulukina }\end{array}$ & 2828.8 & 3 & 1.74 & 3 & 3 & 20 & 2 & 3 & 3.49 & 50 & 4.20 \\
\hline Koppa & 1052.7 & 2 & 1.95 & 3 & 2 & 22 & 4 & 2 & 3.9 & 50 & 1.56 \\
\hline Keresara & 462.9 & 4 & 0.57 & 3 & 2 & 8 & 5 & 4 & 1.14 & 50 & 0.69 \\
\hline Taragod & 9509.4 & 5 & 21.14 & 5 & 4 & 43 & 5 & 3 & 35.24 & 60 & 14.11 \\
\hline $\begin{array}{l}\text { Ambalike } \\
\text { Kathlehall }\end{array}$ & 5374 & 4 & 7.3 & 5 & 5 & 35 & 4 & 5 & 9.29 & 79 & 7.98 \\
\hline a & 14022 & 3 & 19.05 & 3 & 5 & 51 & 3 & 2 & 34.64 & 55 & 20.81 \\
\hline $\begin{array}{l}\text { Nidagod } \\
\text { Anchigad } \\
\text { de }\end{array}$ & 2396.5 & 3 & 2.96 & 4 & 3 & 15 & 1 & 1 & 3.55 & 83 & 3.56 \\
\hline Chowdi & 1183 & 4 & 0.87 & 4 & 2 & 20 & 1 & 2 & 1.46 & 60 & 1.76 \\
\hline $\begin{array}{l}\text { Mooliman } \\
\text { e Nidagod }\end{array}$ & 1544.5 & 3 & 1.14 & 2 & 1 & 14 & 4 & 4 & 1.9 & 60 & 2.29 \\
\hline $\begin{array}{l}\text { Manthagu } \\
\text { li }\end{array}$ & 751 & 4 & 0.46 & 2 & 4 & 17 & 2 & 2 & 0.92 & 50 & 1.11 \\
\hline Belale & 2524.2 & 5 & 4.36 & 5 & 5 & 19 & 4 & 5 & 7.48 & 58 & 3.75 \\
\hline $\begin{array}{l}\text { Basavana } \\
\text { Shindiger }\end{array}$ & 3808.5 & 5 & 4.7 & 3 & 4 & 18 & 5 & 4 & 9.41 & 50 & 5.65 \\
\hline $\begin{array}{l}\text { Hanmanth } \\
\text { Devara } \\
\text { Bekkina }\end{array}$ & 5733.4 & 5 & 7.08 & 5 & 5 & 6 & 3 & 4 & 14.16 & 50 & 8.51 \\
\hline $\begin{array}{l}\text { Jaddi } \\
\text { Kelagima } \\
\text { Bommana }\end{array}$ & 849.8 & 2 & 0.52 & 4 & 2 & 11 & 2 & 1 & 1.05 & 50 & 1.26 \\
\hline $\begin{array}{l}\text { lli } \\
\text { Kadave }\end{array}$ & 69.9 & 2 & 0.03 & 3 & 1 & 11 & 1 & 1 & 0.06 & 50 & 0.10 \\
\hline $\begin{array}{l}\# 1 \\
\text { Kadave }\end{array}$ & 1352.9 & 3 & 2.5 & 3 & 2 & 44 & 2 & 2 & 4.01 & 62 & 2.01 \\
\hline$\# 2$ & 345.8 & 2 & 0.17 & 4 & 2 & 25 & 5 & 1 & 0.34 & 50 & 0.51 \\
\hline $\begin{array}{l}\text { Bommana } \\
\text { lli }\end{array}$ & 2753.7 & 4 & 2.04 & 4 & 4 & 26 & 5 & 4 & 4.08 & 50 & 4.09 \\
\hline Konkana & 1588.7 & 4 & 0.78 & 4 & 3 & 14 & 3 & 2 & 1.17 & 67 & 2.36 \\
\hline Golikoppa & 1635.1 & 3 & 1.21 & 5 & 3 & 41 & 5 & 4 & 2.42 & 50 & 2.43 \\
\hline
\end{tabular}




\begin{tabular}{llllllllllll} 
Ashisara & 1187.9 & 2 & 1.46 & 2 & 1 & 23 & 2 & 4 & 2.93 & 50 & \\
Dalavaayi & 2160.8 & 3 & 1.6 & 4 & 4 & 40 & 4 & 4 & 3.2 & 50 & 3.21 \\
\hline
\end{tabular}

Performance indicator values of irrigation tanks in the study area. 


\begin{tabular}{|c|c|c|c|c|c|c|c|c|c|}
\hline & $\begin{array}{c}\text { Tank } \\
\text { Conditio } \\
\mathrm{n}\end{array}$ & $\begin{array}{c}\text { Water } \\
\text { Holding } \\
\text { Capacit } \\
y \\
\end{array}$ & $\begin{array}{c}\text { Vegetati } \\
\text { on } \\
\text { Health } \\
\end{array}$ & $\begin{array}{c}\text { Wildlife } \\
\text { Habitat } \\
\text { Health }\end{array}$ & $\begin{array}{l}\text { Acreage } \\
\text { Irrigated }\end{array}$ & $\begin{array}{c}\text { Access and } \\
\text { Convenienc } \\
\mathrm{e}\end{array}$ & $\begin{array}{c}\text { Usa } \\
\text { bilit } \\
\text { y }\end{array}$ & $\begin{array}{l}\text { Potentia } \\
1 \text { Storage } \\
\end{array}$ & $\begin{array}{c}\text { Composite } \\
\text { Sustainability } \\
\text { Index }\end{array}$ \\
\hline Gadigehole & 2.5 & 0.4 & 2.5 & 0.0 & 0.9 & 0.0 & 0.0 & 0.3 & 1.0 \\
\hline Bugadimane & 7.5 & 2.2 & 2.5 & 2.5 & 10.0 & 2.5 & 5.0 & 2.6 & 4.1 \\
\hline Kibballi & 7.5 & 0.5 & 7.5 & 7.5 & 5.5 & 2.5 & 7.5 & 0.5 & 3.6 \\
\hline Ashimane & 10.0 & 0.5 & 10.0 & 10.0 & 1.5 & 2.5 & 7.5 & 0.5 & 4.4 \\
\hline Halige & 7.5 & 0.3 & 5.0 & 5.0 & 0.5 & 10.0 & 5.0 & 0.2 & 3.4 \\
\hline Devarakeri & 10.0 & 2.2 & 10.0 & 7.5 & 1.1 & 7.5 & 10.0 & 1.3 & 5.1 \\
\hline $\begin{array}{l}\text { Keshinamane } \\
\text { Appurayanaja }\end{array}$ & 7.5 & 0.3 & 5.0 & 5.0 & 9.4 & 5.0 & 5.0 & 0.3 & 3.5 \\
\hline $\begin{array}{l}\text { ddi } \\
\text { Hakkimane }\end{array}$ & 5.0 & 5.0 & 7.5 & 5.0 & 0.5 & 2.5 & 2.5 & 6.0 & 5.2 \\
\hline $\begin{array}{l}\# 1 \\
\text { Hakkimane }\end{array}$ & 5.0 & 0.3 & 5.0 & 7.5 & 1.3 & 5.0 & 2.5 & 0.4 & 2.7 \\
\hline Emme & 7.5 & 1.6 & 10.0 & 7.5 & 2.1 & 10.0 & 10.0 & $\begin{array}{l}0.0 \\
1.9\end{array}$ & 4.8 \\
\hline Jaanamakki & 7.5 & 7.4 & 10.0 & 10.0 & 3.8 & 10.0 & 5.0 & 7.4 & 7.8 \\
\hline Chowdi & 0.0 & 3.7 & 2.5 & 2.5 & 0.5 & 10.0 & 7.5 & 3.6 & 2.9 \\
\hline Malenalli & 2.5 & 0.8 & 5.0 & 2.5 & 1.7 & 10.0 & 0.0 & 1.0 & 2.2 \\
\hline Arsapura & 0.0 & 1.2 & 7.5 & 7.5 & 0.7 & 2.5 & 2.5 & 1.4 & 1.8 \\
\hline Nagarakura & 5.0 & 3.9 & 2.5 & 2.5 & 5.5 & 2.5 & 0.0 & 3.7 & 3.9 \\
\hline $\begin{array}{l}\text { Beerala } \\
\text { Mulukina }\end{array}$ & 5.0 & 0.8 & 5.0 & 5.0 & 3.6 & 2.5 & 5.0 & 0.9 & 2.7 \\
\hline Koppa & 2.5 & 0.9 & 5.0 & 2.5 & 4.0 & 7.5 & 2.5 & 1.0 & 2.2 \\
\hline Keresara & 7.5 & 0.2 & 5.0 & 2.5 & 1.3 & 10.0 & 7.5 & 0.3 & 3.3 \\
\hline Taragod & 10.0 & 10.0 & 10.0 & 7.5 & 8.7 & 10.0 & 5.0 & 10.0 & 9.7 \\
\hline Ambalike & 7.5 & 3.4 & 10.0 & 10.0 & 6.5 & 7.5 & 10.0 & 2.6 & 5.5 \\
\hline Kathlehalla & 5.0 & 9.0 & 5.0 & 10.0 & 9.6 & 5.0 & 2.5 & 9.8 & 7.8 \\
\hline Nidagod & 5.0 & 1.3 & 7.5 & 5.0 & 2.6 & 0.0 & 0.0 & 0.9 & 2.7 \\
\hline Anchigadde & 5.0 & 1.2 & 2.5 & 2.5 & 2.5 & 2.5 & 2.5 & 1.3 & 2.6 \\
\hline $\begin{array}{l}\text { Chowdi } \\
\text { Moolimane }\end{array}$ & 7.5 & 0.3 & 7.5 & 2.5 & 3.6 & 0.0 & 2.5 & 0.3 & 2.9 \\
\hline Nidagod & 5.0 & 0.5 & 2.5 & 0.0 & 2.5 & 7.5 & 7.5 & 0.5 & 2.4 \\
\hline Manthaguli & 7.5 & 0.2 & 2.5 & 7.5 & 3.0 & 2.5 & 2.5 & 0.2 & 3.0 \\
\hline Belale & 10.0 & 2.0 & 10.0 & 10.0 & 3.4 & 7.5 & 10.0 & 2.1 & 5.6 \\
\hline Basavana & 10.0 & 2.2 & 5.0 & 7.5 & 3.2 & 10.0 & 7.5 & 2.6 & 5.5 \\
\hline $\begin{array}{l}\text { Shindigere } \\
\text { Hanmanth }\end{array}$ & 5.0 & 0.8 & 7.5 & 2.5 & 1.5 & 2.5 & 0.0 & 1.0 & 2.6 \\
\hline Devara & 10.0 & 3.3 & 10.0 & 10.0 & 0.9 & 5.0 & 7.5 & 4.0 & 6.2 \\
\hline $\begin{array}{l}\text { Bekkina Jaddi } \\
\text { Kelagima }\end{array}$ & 2.5 & 0.2 & 7.5 & 2.5 & 1.9 & 2.5 & 0.0 & 0.2 & 1.6 \\
\hline Bommanalli & 2.5 & 0.0 & 5.0 & 0.0 & 1.9 & 0.0 & 0.0 & 0.0 & 1.0 \\
\hline Kadave \#1 & 5.0 & 1.1 & 5.0 & 2.5 & 8.2 & 2.5 & 2.5 & 1.1 & 2.8 \\
\hline Kadave \#2 & 2.5 & 0.0 & 7.5 & 2.5 & 4.6 & 10.0 & 0.0 & 0.0 & 2.0 \\
\hline Bommanalli & 7.5 & 0.9 & 7.5 & 7.5 & 4.8 & 10.0 & 7.5 & 1.1 & 4.3 \\
\hline Konkana & 7.5 & 0.3 & 7.5 & 5.0 & 2.5 & 5.0 & 2.5 & 0.3 & 3.3 \\
\hline Golikoppa & 5.0 & 0.5 & 10.0 & 5.0 & 7.6 & 10.0 & 7.5 & 0.6 & 3.5 \\
\hline Ashisara & 2.5 & 0.6 & 2.5 & 0.0 & 4.2 & 2.5 & 7.5 & 0.8 & 1.6 \\
\hline
\end{tabular}




\begin{tabular}{lcccccccc}
$\begin{array}{l}\text { Dalavaayi } \\
\text { Minimum }\end{array}$ & 5.0 & 0.7 & 7.5 & 7.5 & 7.5 & 7.5 & 7.5 & 0.8 \\
$\begin{array}{l}\text { Value } \\
\text { Maximum }\end{array}$ & 1 & 0.03 & 1 & 1 & 1 & 1 & 1 & 0.06 \\
Value & 10 & 21.14 & 10 & 10 & 53 & 10 & 10 & 35.24 \\
\hline
\end{tabular}

Normalized performance values of irrigation tanks on a scale of 0 to 10 . 


\section{Survey of Irrigation Tanks in the Study Area}

\section{FIU मових \\ INTERNATIONAL \\ UNIVERSITY}

Date:

\section{Survey of Water Tanks in Study Area}

1. Name of the tank (Kere):

2. Name of the village (Grama):

3. Name of Panchayat:

Coordinates and elevation of the selected points around the tank (for me to fill):

\begin{tabular}{|l|l|l|l|}
\hline \multicolumn{1}{|c|}{ Points } & Latitude & Longitude & Elevation \\
\hline A & & & \\
\hline B & & & \\
\hline C & & & \\
\hline D & & & \\
\hline E & & & \\
\hline F & & & \\
\hline G & & & \\
\hline H & & & \\
\hline I & & & \\
\hline J & & & \\
\hline
\end{tabular}

4. Observations of the general condition of the tank:

5. Water depth (2016-2017)

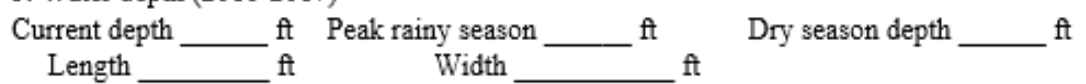

5a. Has this tank been affected by the water shortage in the past 5 years? YES ___ NO

6. Answer only if $5 \mathrm{a}$ is a YES. What was the last year where the tank reached full capacity?

6a. What was the water depth during this year?

Rainy season depth

Dry season depth $\mathrm{ft}$

7. How many acres of farm downstream does this tank supply water to?

8. Has the tank been restored within the last 5 years? YES NO

8a. If you answered YES to the above question, what year was the tank restored?

8b. If you answered YES to the above question, who paid for the restoration of the tank?

Government

Community

Price

8c. Are there any plans for restoration of this tank, whether through Government or Community means, for the future? YES [year expected] NO

9. Is the tank currently being utilized for irrigation purposes? YES

NO

9a. If you answered YES to the above question, has the efficiency of water use declined in the last 5 years? YES NO

10. Is the tank used for any purpose other than irrigation? Circle all the following that apply.
Human use (bathing, washing) Fishing
Washing animals
Industry
Wildlife Habitat 


\section{FIU}

\section{VERBAL CONSENT TO PARTICIPATE IN A RESEARCH STUDY}

Hello, my name is Nicholas Charles. You have been chosen at random to participate in a research study about the use of water resources in agriculture and other purposes in your area. The purpose of this study is to identify how producers view the declining availability of water resources, how efficient the current agricultural water use is, and the potential benefits of proper harnessing and storing water resources in your villages. I am conducting this survey with the assistance of Hulgol Service Cooperative Society, Bhairumbe. If you would like to take this survey, please review the following information:

\section{NUMBER OF STUDY PARTICIPANTS}

You are one among 300 participants who will be randomly interviewed in this survey.

\section{DURATION OF THE STUDY}

The completion of the survey will take approximately 30-45 minutes.

\section{RISKS AND/OR DISCOMFORTS}

There are no known risks to participating in this study.

\section{BENEFITS}

The main benefit of participating in this study is that you will gain a better understanding of the amount of water you currently use, its benefit and the future of water resources in your region. The results of this study may yield better government policies relating to water resources in your area, which will ultimately benefit farmers in general.

\section{CONFIDENTIALITY}

The records of this study will be kept private and will be protected. In any sort of report, we might publish, we will not include any information that will make it possible to identify you as a subject. Research records will be stored securely and only the researcher team will have access to the records. Your participation is voluntary and anonymous, and you will not be penalized or lose benefits if you refuse to participate or decide to stop.

\section{COMPENSATION \& COSTS}

There is no cost or payment to you.

\section{RIGHT TO DECLINE OR WITHDRAW}

Your participation in this study is voluntary. You are free to participate in the study or withdraw your consent at any time during the study. Your withdrawal or lack of participation will not affect any benefits to which you are otherwise entitled.

\section{RESEARCHER CONTACT INFORMATION}

If you have any questions about the purpose, procedures, or any other issues related to this research study, you may contact one of the following:

Dr. Mahadev Bhat at Florida International University, Miami, Florida, USA by phone: +1 (305) 305-3481210, or by e-mail at Mahadev.Bhat@fiu.edu.

\section{IRB CONTACT INFORMATION at FIU}

If you would like to talk with someone about your rights of being a subject in this research study or about ethical issues with this research study, you may contact the FIU Office of Research Integrity by phone at +1 (305) 348-2494 or by email at ori@fiu.edu. 


\section{PARTICIPANT AGREEMENT}

- I have read the information in this consent form and agree to participate in this study. I have had a chance to ask any questions I have about this study, and they have been answered for me

\section{A. General Questions about your Farm and Water Use}

Date:

Elevation:

1. What village do you live in?

2. What kind of farm do you run?

Orchard (arecanut, coconut, black pepper, cardamom, banana)

Rice cultivation

Sugarcane

Dairy and other animals

Betta land irrigation

3. How many acres of land does your farm family own, cultivate, and/or use?

Arecanut \& other orchard crops

Rice paddy

Coconut (out of orchard)

Fruits

Pasture (bena)

Soppinabetta

Dwelling house and farm-shed area

Total

Inherited___ Bought ___ Conversion of cropland/other- lands

4. What is the average amount of water that your family consumes per day (Household) in liters OR in buckets

5. Is the current availability of water enough to meet your daily demands all throughout the year? YES NO

5a. If NO, since when has the current water availability not been enough? Year

6. Have you noticed a decline in water availability in your area and if so, when did it start?

Yes, the overall water availability on my farm has declined since [Year

No, the overall water availability has increased over the years

No, I have not noticed any changes in the water availability

(6a) How many months during the year have you been experiencing water shortage? Circle the appropriate number of months below. 
$\begin{array}{llllllllll}\text { In months: } & 1 & 2 & 3 & 4 & 5 & 6 & 7 & 8 & \text { throughout the }\end{array}$ year

(6b part 1) Which are the most critical months?

Months:

(6b part 2) Are all your crops affected in these critical months? Yes

No

(6c) In your village, what are the local reasons for the declining water availability in these critical months? (Y/N to all that apply)

Increased crop area

Decline in rainfall during pre/post monsoon period

Diversion of river/creek water

Decline in vegetation

Other reasons?

(6d) What changes have you seen in your surrounding environment due to less water?

(6e) Which of the following impacts or outcomes have you noticed on your farm and/or household?

Loss of crop yield

Loss (death) of trees

Increased pests and diseases

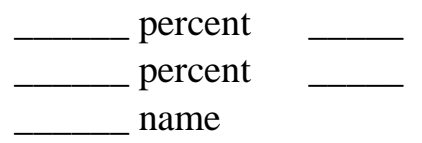

Increased costs of cultivation/ labor costs

Other impacts (

7. Has the quality of water (such as color or taste) changed in the past 5 years? _ Y Yes No

8. Have you observed the overall economic status of the families in your community to have improved during the last 10 years? If yes, what are the reasons? YES

NO

1. Increased yield

2. Increased price

3. Non-farm income

4. Diversified crops

5. Others (specify)

\section{B. Questions on Irrigation and Crops at Your Farm}

1. What is your primary source of water for both agricultural and household needs?

\begin{tabular}{|l|l|l|l|l|l|}
\hline Crop or Activity & \multicolumn{5}{|c|}{ Source of Water } \\
\cline { 2 - 6 } & $\begin{array}{l}\text { Bore } \\
\text { Well }\end{array}$ & $\begin{array}{l}\text { Open } \\
\text { Well }\end{array}$ & $\begin{array}{l}\text { River, } \\
\text { Canal \& } \\
\text { creeks }\end{array}$ & $\begin{array}{l}\text { Tank } \\
(\text { Kere })^{1}\end{array}$ & Rainfed \\
\hline
\end{tabular}




\begin{tabular}{|l|l|l|l|l|l|}
\hline $\begin{array}{l}\text { Areca (Orchard) Banana, Pepper, } \\
\text { Coconut, Cardamom }\end{array}$ & & & & & \\
\hline Rice paddy & & & & & \\
\hline Coconut (out of orchard) & & & & & \\
\hline Fruits & & & & & \\
\hline Vegetable & & & & & \\
\hline Animal husbandry & & & & & \\
\hline Home gardening & & & & & \\
\hline Drinking, cleaning and bathing & & & & & \\
\hline Other uses & & & & & \\
\hline
\end{tabular}

Please indicate the name of river and/or tank if applicable

2. What are the main methods of irrigation on your farm?

(Put a CHECK mark under as many irrigation method as applicable for each crop or activity)

\begin{tabular}{|l|l|l|l|l|l|l|}
\hline \multirow{2}{*}{ Crop or Activity } & \multicolumn{5}{|c|}{ Method of Irrigation } \\
\cline { 2 - 7 } & $\begin{array}{l}\text { Furrow } \\
\text { Irrigation }\end{array}$ & $\begin{array}{l}\text { Border } \\
\text { Irrigation }\end{array}$ & $\begin{array}{l}\text { Basin } \\
\text { Irrigation }\end{array}$ & $\begin{array}{l}\text { Drip } \\
\text { Irrigation }\end{array}$ & $\begin{array}{l}\text { Sprinkler } \\
\text { Irrigation }\end{array}$ & $\begin{array}{l}\text { Manual } \\
\text { Irrigation }\end{array}$ \\
\hline Areca (Orchard) & & & & & & \\
\hline Rice paddy & & & & & & \\
\hline $\begin{array}{l}\text { Coconut (out of } \\
\text { orch) }\end{array}$ & & & & & & \\
\hline Fruits & & & & & & \\
\hline Vegetable & & & & & & \\
\hline Animal husbandry & & & & & & \\
\hline Home gardening & & & & & & \\
\hline $\begin{array}{l}\text { Drinking, cleaning } \\
\text { and bathing }\end{array}$ & & & & & & \\
\hline
\end{tabular}

3. Please provide the following details on the irrigation and residential drinking water wells.

\begin{tabular}{|l|l|l|l|l|l|}
\hline $\begin{array}{l}\text { Sr. } \\
\text { No. }\end{array}$ & $\begin{array}{l}\text { Type of well } \\
\text { (open well or } \\
\text { bore well) }\end{array}$ & $\begin{array}{l}\text { Depth } \\
(\mathrm{ft})\end{array}$ & $\begin{array}{l}\text { Width } \\
(\mathrm{ft})\end{array}$ & $\begin{array}{l}\text { Water Table in Peak } \\
\text { Rainy Month (ft) }\end{array}$ & $\begin{array}{l}\text { Water Table in Peak } \\
\text { Summer Month (ft) }\end{array}$ \\
\hline 1. & & & & & \\
\hline 2. & & & & & \\
\hline 3. & & & & & \\
\hline 4. & & & & & \\
\hline
\end{tabular}

4. During the last 5 years, what, if any, investments have been made to improve the water supply? Please include investments that failed as well. 


\begin{tabular}{|l|l|l|}
\hline Investment Practice & Amount (₹) & Success or Failure \\
\hline Bore Well & & \\
\hline Open Well & & \\
\hline Deepening existing wells & & \\
\hline Sprinkler system & & \\
\hline Drip system & & \\
\hline Rainwater harvesting & & \\
\hline Ground water recharge facility & & \\
\hline Other (Specify) & & \\
\hline
\end{tabular}

5. Please provide the following details on pump set installed in your house and farm.

\begin{tabular}{|l|l|l|l|l|}
\hline $\begin{array}{l}\text { Sr. } \\
\text { No. }\end{array}$ & Horse Power & Main Use & & $\begin{array}{l}\text { Average Hours of } \\
\text { Use per Week }\end{array}$ \\
\hline 1. & & & $\begin{array}{l}\text { Number of months } \\
\text { of use in a year }\end{array}$ \\
\hline 2. & & & & \\
\hline 3. & & & & \\
\hline 4. & & & & \\
\hline 5. & & & & \\
\hline
\end{tabular}

${ }^{1}$ Code for Main Use: 1 = Irrigation; 2 = Residential; 3 = Animal husbandry; 4 = Multi-purpose

6. Please provide the following details on crop and animal husbandry production, water consumption and income generated from various activities on your farm and in your household during the last year.

\section{(June 2016 - May 2017)}

\begin{tabular}{|l|l|l|l|l|}
\hline \multirow{2}{*}{$\begin{array}{l}\text { Crop or Animal } \\
\text { Activity Name }\end{array}$} & \multicolumn{3}{|c|}{ Areca Orchard } \\
\cline { 2 - 5 } Total area in acres OR & Arecanut & Pepper & Banana & Other( \\
$\begin{array}{l}\text { No. of units (e.g., animals or } \\
\text { cattle heads) }\end{array}$ & \multicolumn{4}{|l|}{} \\
\hline $\begin{array}{l}\text { Season: 1 = year round, 2 } \\
\text { rainy season, 3 = winter, or 4 } \\
\text { summer }\end{array}$ & & & & \\
\hline $\begin{array}{l}\text { Total production: } \\
\text { Unit (quintal, etc.) } \\
\text { Quantity }\end{array}$ & - & & & \\
\hline Quantity sold & & & & \\
\hline Average price sold at (₹) & & & & \\
\hline
\end{tabular}




\begin{tabular}{|c|c|c|c|c|}
\hline $\begin{array}{l}\text { Crop or Animal } \\
\text { Activity Name }\end{array}$ & Rice & $\begin{array}{l}\text { Coconut (out } \\
\text { of orchard) }\end{array}$ & Fruit & Vegetable \\
\hline \multicolumn{5}{|l|}{$\begin{array}{l}\text { Total area in acres OR } \\
\text { No. of units (e.g., } \\
\text { animals or cattle heads) }\end{array}$} \\
\hline \multicolumn{5}{|l|}{$\begin{array}{l}\text { Season: } 1=\text { year round, } 2 \\
=\text { rainy season, } 3= \\
\text { winter, or } 4=\text { summer }\end{array}$} \\
\hline \multicolumn{5}{|l|}{$\begin{array}{l}\text { Total production: } \\
\text { Unit (quintal, etc.) } \\
\text { Quantity }\end{array}$} \\
\hline \multicolumn{5}{|l|}{ Quantity sold } \\
\hline \multicolumn{5}{|l|}{ Average price sold at (₹) } \\
\hline \multicolumn{5}{|l|}{$\begin{array}{l}\text { Water usage for this } \\
\text { activity: } \\
\text { HP of the machine } \\
\text { Hours of pumping } \\
\text { per day }\end{array}$} \\
\hline $\begin{array}{l}\text { during: } \\
\text { Jan - March } \\
\text { Apr - Jun } \\
\text { Jul - Sept } \\
\text { Oct - Dec }\end{array}$ & & & & \\
\hline \multicolumn{5}{|l|}{$\begin{array}{l}\text { Irrigation method } \\
\text { (surface, etc.) }\end{array}$} \\
\hline $\begin{array}{l}\text { Irrigation source (well, } \\
\text { tank, etc.) }\end{array}$ & & & & \\
\hline
\end{tabular}

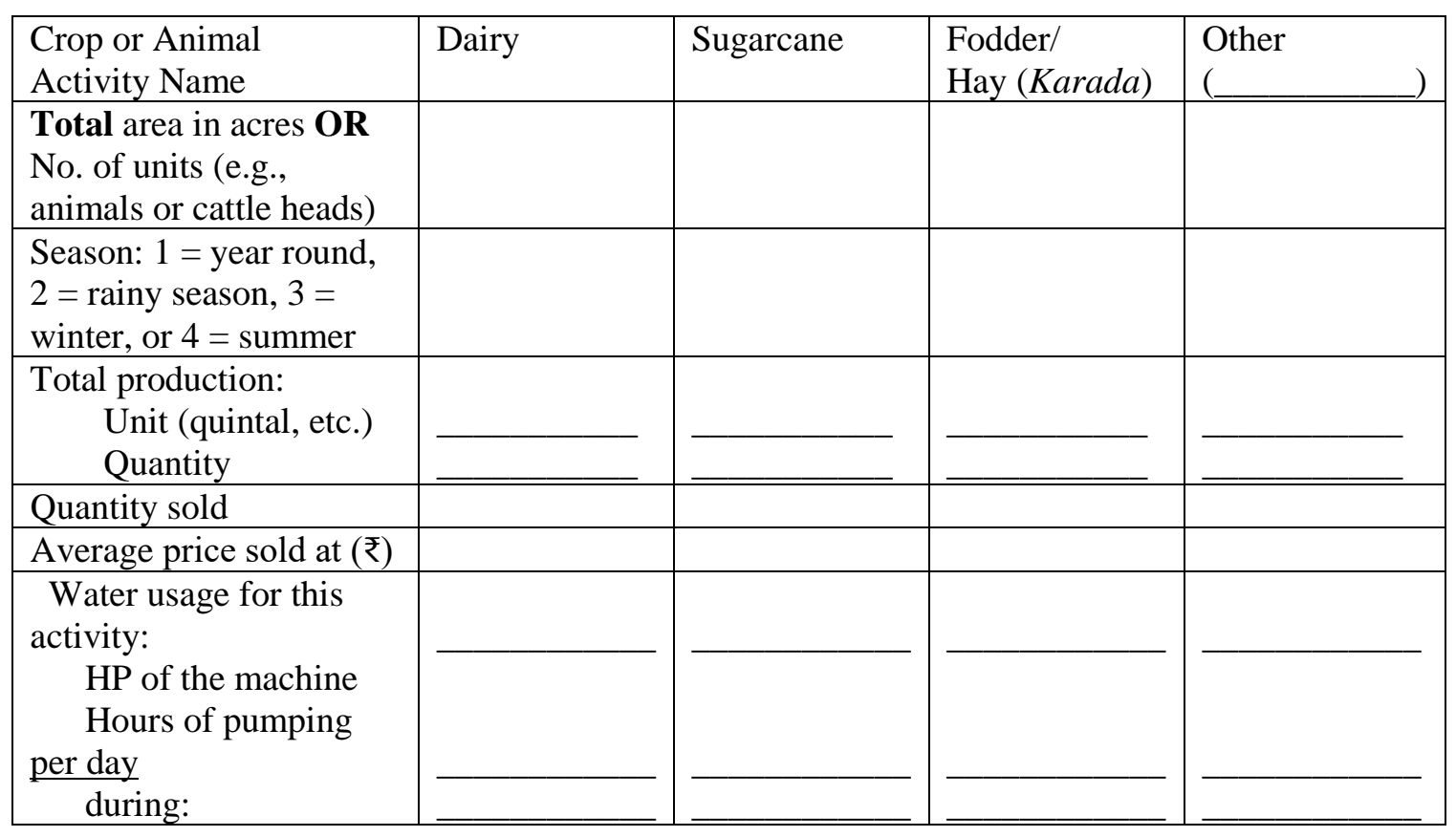




\begin{tabular}{|l|l|l|l|l|}
\hline $\begin{array}{l}\text { Jan - March } \\
\text { Apr - Jun } \\
\text { Jul - Sept }\end{array}$ & - & & & \\
Oct - Dec & - & & & \\
\hline $\begin{array}{l}\text { Irrigation method } \\
\text { (surface, etc.) }\end{array}$ & & & & \\
\hline $\begin{array}{l}\text { Irrigation source (well, } \\
\text { tank, etc.) }\end{array}$ & & & & \\
\hline
\end{tabular}

7. Are you familiar with a new lift irrigation project that the government has been considering to increase water availability in this area? Yes No

\section{Note to the Interviewer: If "No", give the following description to the respondent:}

The construction of check dams across the Shalmala River in Sonde village and Devaru Hole has been proposed, pumping only the excess water during the rainy season, storing it in holding tanks and distributing the same to various tanks (kere) located in multiple villages in your Grama Panchayat during summer months to use the new-found water resource as needed. Please note the Shalmala river project is still under review and no final decision is made.

8. Do you feel that these irrigation projects will benefit your farm? If so, select one or more options that best represent your view about this new lift irrigation project.

Additional water will help me expand the area of existing crops Additional water will help me grow a variety of NEW crops If checked, please list the name of crops:

Yes, the new irrigation project will supply more water for my household needs Other benefits (explain)

9. If this project does not happen, how will you manage your water use and needs in the future if water availability continues to decrease?

\section{Individual Information}

1. What is your age?

2. Gender

3. Married/Single/Widowed? (circle one) 
4. Number of members in your household living on the farm and outside the farm

5. Education level:

$\begin{array}{lll}\text { _ No formal schooling } & \text { _ Primary school } & \text { High school } \\ \text { _ College degree } & \ldots \text { Vocational degree } & \text { _ Pre college degree }\end{array}$

6. Do any of your family members have off-farm occupation? ___ Yes __ No $6 a$. If Yes, what is the occupation?

6 b. How much water does your off-farm occupation require daily? Liters 